Florida International University FIU Digital Commons

3-24-2009

\title{
Argentine music styles contributions to contemporary jazz language : analysis of six original compositions
}

\author{
Agustin A. Conti \\ Florida International University
}

DOI: $10.25148 /$ etd.FI14060898

Follow this and additional works at: https://digitalcommons.fiu.edu/etd

Part of the Music Commons

\section{Recommended Citation}

Conti, Agustin A., "Argentine music styles contributions to contemporary jazz language : analysis of six original compositions" (2009). FIU Electronic Theses and Dissertations. 2428.

https://digitalcommons.fiu.edu/etd/2428 
FLORIDA INTERNATIONAL UNIVERSITY

Miami, Florida

\title{
ARGENTINE MUSIC STYLES CONTRIBUTIONS TO CONTEMPORARY JAZZ LANGUAGE: ANALYSIS OF SIX ORIGINAL COMPOSITIONS
}

\author{
A thesis submitted in partial fulfillment of the \\ requirements for the degree of \\ MASTER OF MUSIC
}

by

Agustin A. Conti

2009 
To: Acting Dean Brian Schriner

College of Architecture and the Arts

This thesis, written by Agustin A. Conti, and entitled Argentine Music Styles Contributions to Contemporary Jazz Language: Analysis of Six Original Compositions, having been approved in respect to style and intellectual content, is referred to you for judgment.

We have read this thesis and recommend that it be approved.

Mike Orta

Sam Lussier

Gary Campbell, Major Professor

Date of Defense: March 24, 2009

The thesis of Agustin A. Conti is approved.

Acting Dean Brian Schriner College of Architecture and the Arts

Dean George Walker University Graduate School

Florida International University, 2009 


\section{DEDICATION}

I dedicate this thesis to my wife Carla. Without her patience, understanding, support, and most of all love, the completion of this work would not have been possible. 


\section{ABSTRACT OF THE THESIS \\ ARGENTINE MUSIC STYLES CONTRIBUTIONS TO CONTEMPORARY JAZZ \\ LANGUAGE: ANALYSIS OF SIX ORIGINAL COMPOSITIONS}

by

Agustin A. Conti

Florida International University, 2009

Miami, Florida

Professor Gary Campbell, Major Professor

The purpose of this thesis is to present and analyze six original compositions and arrangements by Agustin A. Conti that demonstrate the influence of Argentinean music on Jazz composition. Conti's compositions combine elements of the Chacarera, Candombe, Murga, Milonga, and Malambo styles, with the odd-meter ostinato and metric modulation used in modern Latin jazz. The thesis includes scores of the six works, as well as a $\mathrm{CD}$ of the thesis recital, performed by a jazz quartet consisting of tenor saxophone (or soprano), piano, electric bass and drum set. 


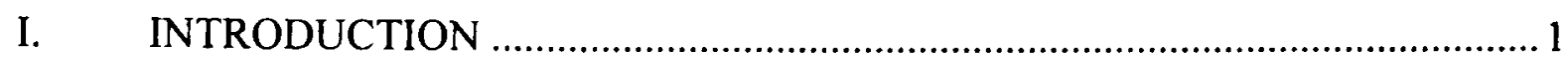

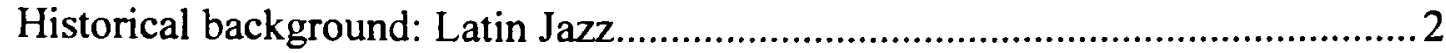

An Ever-Evolving Art Form .................................................................... 3

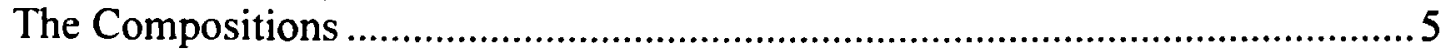

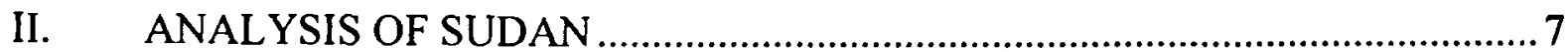

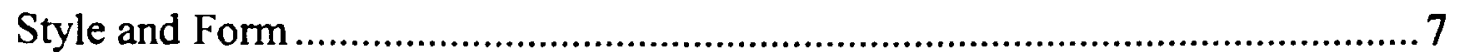

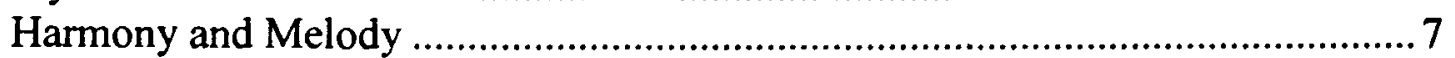

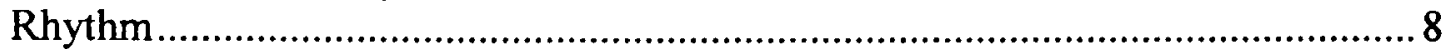

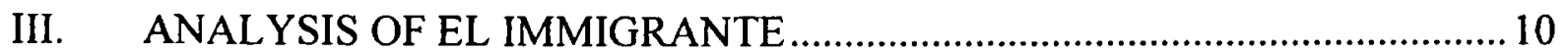

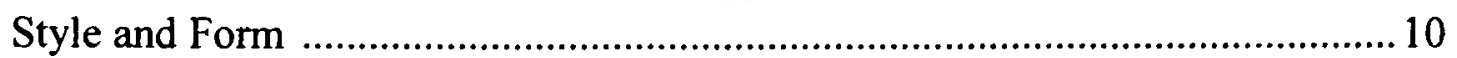

Harmony and Melody ........................................................................... 10

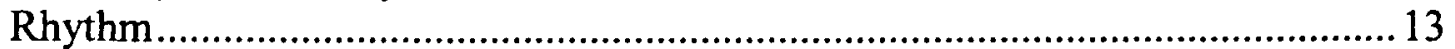

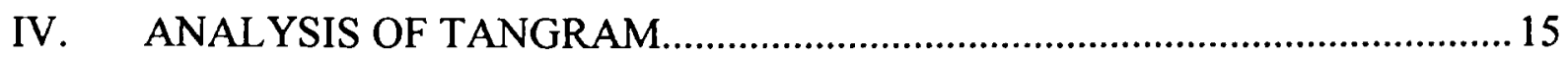

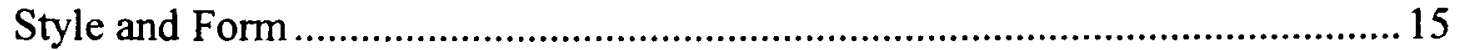

Harmony and Melody ................................................................................ 15

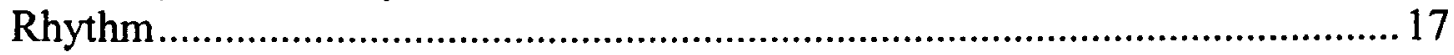

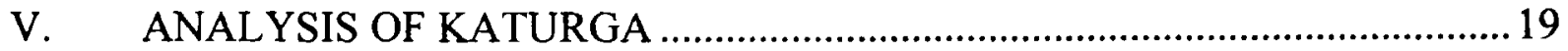

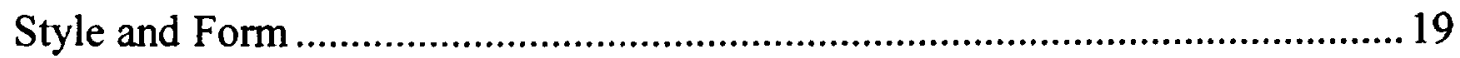

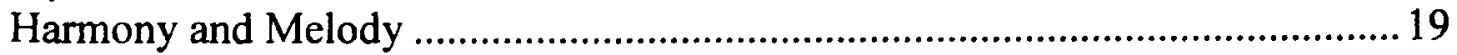

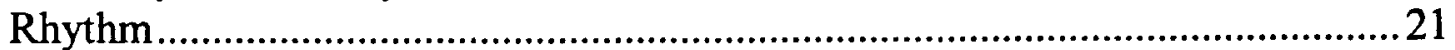

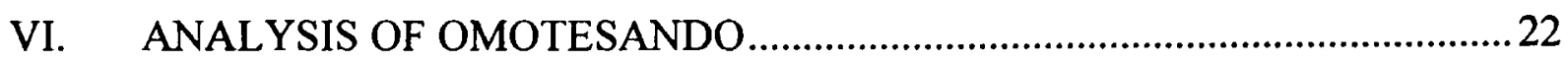

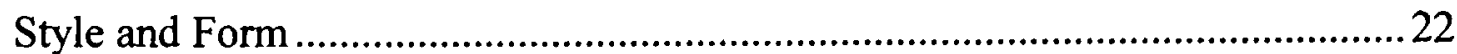

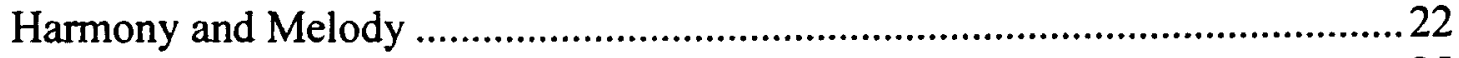

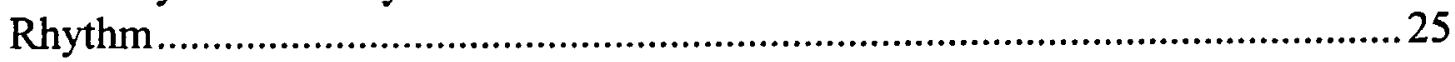

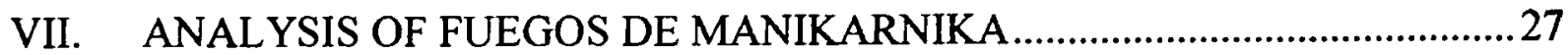

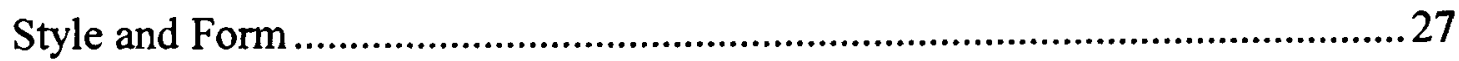

Harmony and Melody ................................................................................... 27

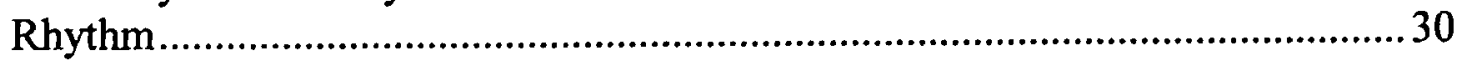

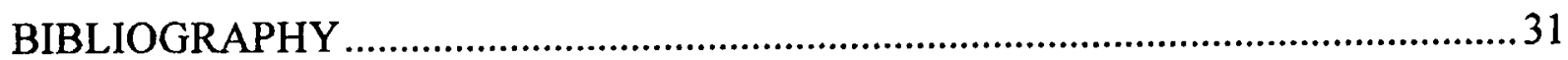

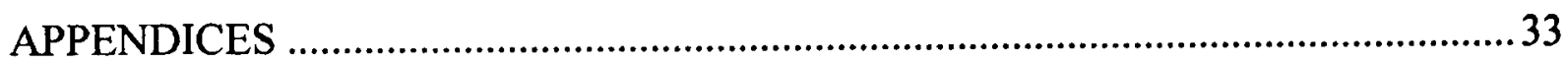




\section{LIST OF FIGURES}

FIGURES

PAGE

1. Example 2-1: Sudan, bars 5 and 6 of the blues pattern.............................................. 8

2. Example 2-2: Sudan, Opening bass ostinato with repeated clave.................................9

3. Example 2-3: Sudan, Rhythmic ostinato continuing against the melody....................9

4. Example 3-1: El Immigrante, introductory bass pattern ............................................. 10

5. Example 3-2: El Immigrante, B section harmonic movement....................................11

6. Example 3-3: El Immigrante, first eight bars of $\mathrm{C}$ section. ......................................... 12

7. Example 3-4: El Immigrante, last four bars of $\mathrm{C}$ section.............................................. 13

8. Example 4-1: Tangram, opening piano-bass unison pattern.....................................16

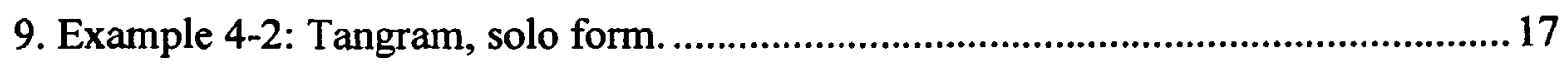

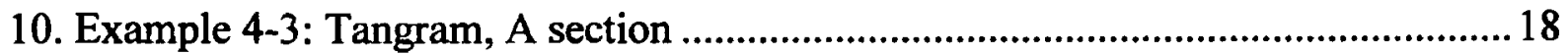

11. Example 5-1: Katurga, introductory chords.............................................................20

12. Example 5-2: Katurga, mm. 1-4 of $\mathrm{C}$ and $\mathrm{D}$ sections.............................................21

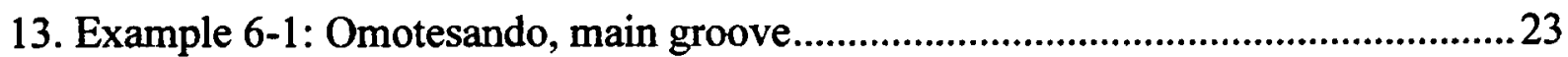

14. Example 6-2: Omotesando, B section harmonic movement.......................................24

15. Example 6-3: Omotesando, melodic climax at measure 47.......................................24

16. Example 6-4: Omotesando, interlude 1 and $C$ section, piano part.............................25

17. Example 6-5: Omotesando, rhythmic figures of bass line........................................25

18. Example 7-1: Fuegos de Manikarnika, first 4 bars of sections $A, B$ and $A^{\prime}$............28

19. Example 7-2: Fuegos de Manikarnika, D section......................................................29 


\section{Chapter I: Introduction}

This paper presents analysis of transcriptions of six original compositions.

These works have been selected to demonstrate the usage and influence of folkloric and urban musical elements from Argentinean styles on jazz composition. They include references to Chacarera, Milonga, Malambo, Murga and Candombe. ${ }^{1}$ These influences, along with modern Latin jazz trends like odd-meter ostinato and metric modulation and the use of contemporary and modal harmonies, combine to create a uniquely diverse recital program. This thesis-recital is part of an on-going project aimed at researching and contributing to the development of a new style or sub-style in the vast realm of what we generically know as Latin Jazz today. This new style, sometimes referred as Jazz Argentino $^{2}$ is evolving in the works of contemporary composers living in New York, Boston, and Buenos Aires.

In the recital portion of this thesis, the compositions will be performed by a jazz quartet consisting of tenor and/or soprano saxophone, piano, electric bass and drum set. The use of this classic quartet instrumentation (a small combo) anchors the timbre and textural possibilities in the jazz tradition and allows for individual space and interaction, especially in the open, improvised sections. As usually happens usually in Latin jazz, the stylistic elements are strongly and primarily present in the rhythmic aspect of the compositions, affecting the groove, articulation and phrasing. In their traditional form,

\footnotetext{
${ }^{1}$ These styles, referred to throughout this thesis, are described and exemplified in Appendix I.

${ }^{2}$ The term jazz argentino was first introduced by the group Baby Lopez Furst Trio in their eponymous 1967 album.
} 
these styles are dances and therefore have a simpler harmonic vocabulary, and a stricter formal structure than do the jazz works that they have influenced. For one thing, they do not include improvised solos.

\section{Historical background: Latin Jazz}

The fertile relationship between jazz and Latin styles that developed throughout the twentieth century has been well documented. The first wave of significant Latin music influences was the Argentinean tango, which washed over the US in the 1920s. Next came the Cuban Rumba in the 1930s and the Brazilian Bossa nova in the1940s. ${ }^{3}$ Also in the latter, pivotal decade, the Mambo, a truly American-Latin idiom, began to develop. ${ }^{4}$ According to jazz scholar Raul Fernandez, "By the 1950's Rhumba, Mambo and Cha-cha-cha, developed by Cuban orchestras, became de rigueur in urban dance halls around the Globe." The popular dance music of Cuba became the foundation of a new synthesis, a true hybrid style. Known at first as Afro-Cuban Jazz or Cubop and today as Latin Jazz, this style fuses jazz harmonies and solos with the driving Latin rhythms. Trumpet player and bebop pioneer Dizzy Gillespie, singer and maraca player Machito (Frank Grillo) and West-Coast-based bandleader Stan Kenton were the three creative leaders of the Cubop in the US.

\footnotetext{
${ }^{3}$ John S. Roberts, The Latin Tinge: The Impact of Latin American Music on the United States (New York: Oxford University Press, 1979), 50-1

${ }^{4}$ Ibid., 100

${ }^{5}$ Raul A. Fernandez, From Afro-Cuban Rhythms to Latin Jazz (Berkeley \& Los Angeles: University of California Press, 2006), vii
} 
In the $60 \mathrm{~s}$ and $70 \mathrm{~s}$, jazz musicians emigrating from Argentina began collaborating with their American Counterparts. Some of the most notable included Gato Barbieri, Jorge Dalto, and, in particular, the pianist, arranger, director, and composer Lalo Schifrin, who moved to the United States in 1958 to work as a pianist and arranger for Dizzie Gillespie. Today, six decades after the Cubop movement started, the modern Latin Jazz world encompasses much more than the music of Cuba and Brazil, traditionally the main branches of Latin Jazz. It is also influenced by musical forms and styles from Puerto Rico, Panama, Colombia, Venezuela, Uruguay, Peru, and Argentina, witness the proliferation of new terms like South American Jazz, Afro-Peruvian Jazz, or Argentinean Jazz to denote these hybrid styles.

\section{$\underline{\text { An Ever-Evolving Art Form }}$}

Jazz today remains wide open to influences from anywhere and everywhere. As Norwegian saxophonist Jan Garbarek points out, "We have players from any part of the world doing their own, shall we say, native version. They find their own direction, influenced by their own culture, but still using the very strong basic elements of jazz." Critic Stuart Nicholson coined the term "glocalization" to describe jazz played around the globe:

Glocalization can involve incorporating elements such as national imagery, folkloric, and cultural concerns that give the music relevance to its "local" musical community. These "glocalized" styles use the basic syntax of the classic and contemporary hegemonic American jazz styles-in this context "hegemony" means "the rule of the game" by which others routinely play- that

\footnotetext{
${ }^{6}$ Stuart Nicholson, Is Jazz Dead? (Or has it moved to a new address) (New York: Routledge Taylor \& Francis Group, 2005), 175
} 
has been widely disseminated around the world (the globalization process), but are reinscribed with local significance (the glocalization process). ${ }^{7}$

In his essay "Brazilian Jazz and Friction of Musicalities," Acacio Tadeu de Camargo Piedade of the State University of Santa Catarina suggests that Brazilian jazz musicians, sensitive to the potentially humiliating effects of cultural imperialism, strive "to avoid contamination from the bebop paradigm and seek an expression that is more rooted in Brazil," by drawing on local elements such as the chorinho. Argentinean sociologist Berenice Corti states that "an economic context that, even in crisis times, favors local production and an international artistic context with global languages that favors diversity help to define the expression Jazz Argentino-Argentinean Jazz—in this new century."8

Aside from all these terminological and cultural distinctions and critical concerns, it is to the aesthetic qualities arising from the fusion of Jazz with Argentinean elements that I aim to contribute through these six original compositions presented and analyzed in this thesis.

\footnotetext{
${ }^{7}$ Nicholson, Is Jazz Dead?, 172

${ }^{8}$ Berenice Corti, "Identidad, Jazz Argentino, Y Van" (http://jazzclub.files.wordpress.com/2006/10/identidad_jazz_argentino_y_van.pdf, accessed 19 January 2009).
} 


\section{The Compositions}

This paper follows the order in which the compositions appear on the CD.

- Sudan is a $3 / 4$ meter, twelve-bar minor modal blues; it is dedicated to all African Refugees. It starts with a solo bass introduction that leads to a syncopated bass ostinato. The groove shifts from $6 / 8$ to a Brazilian samba in $3 / 4$ in the solos. This piece is intended to launch the program energetically and excitingly.

- El Immigrante is an extended, through-composed form. The time signature shifts from $15 / 8$ to $9 / 8$ between the A and the B sections. Polyphonic texture is used in the $\mathrm{C}$ section, leading to $\mathrm{D}$, the solos section. This song is dedicated to all immigrants, legal or not, to the US.

- Tangram is a fast-paced, straight-eighth-note subdivision composition inspired by jazz legend Michael Brecker. It is built on a bass-piano unison ostinato. The $\mathrm{C}$ sections possess a half-time $12 / 8$ chacarera feel, providing rest and balance.

- Katurga is a slow chacarera with major-mode harmony and a lighter, happier sound. It opens with a piano-bass rubato section and features the melody in the bass. This song is inspired by and dedicated to my niece Catalina. 
- Omotesando is constructed on a fast, odd, and mixed meter chacarera groove with a $6 / 8$ malambo feel in the B section. ${ }^{9}$ The intention was to bring the chacarera feel in a modern Latin jazz form.

- Fuegos de Manikarnika concludes the program and is inspired by the burning gaths of the holy city of Varanasi, India. ${ }^{10}$ It opens with a fourpart unison line in odd, mixed meter and includes references to the Rioplatenses " Milonga, Murga and Canbombe styles.

\footnotetext{
${ }^{9}$ Mixed meter is the process of a rapid change of meter signature to create unpredictability.

${ }^{10}$ Sacred cremation sites along the Ganges River used for funerary Rites. Manikarnika Gath is the main and most sacred in the city. According to the Hindu religion, being burned here provides an instant gateway to liberation from the cycle of births and rebirths.

${ }^{11}$ Relative to the Rio de la Plata. There is a Rioplatense culture that combines Uruguayan and Argentinean traditions.
} 


\section{Chapter II: Analysis of Sudan}

This composition is dedicated to all refugees and displaced people in Africa and was inspired by one man that found a new life in Boston, Massachusetts as a taxi driver after having been in a Sudanese Refugee Camp.

\section{Style and Form}

This song was influenced by the compositions of Argentinean pianist/composer Guillermo Klein and his application of odd and mixed meter to Argentinean rhythms. It is constructed of a bass ostinato in $\mathrm{Cm} 6$.

The form is a twelve-bar minor modal blues, the perfect vehicle for the mood and inspiration of the composition. The introduction is open and is derived from the bass ostinato. The bridge is open and only played as the opener for the first soloist and before the head out for the drums solo.

\section{Harmony and Melody}

The introduction suggests the $\mathrm{C}$ Dorian mode as the tonal center. Although the standard blues changes have been reharmonized, the conventional blues structural points remain: bars 1, 7, and 11 are all $\mathrm{Cm} 6$ (the tonic minor chord); bar 5 is Fm, the usual IV minor in the blues form; and bar 10 is G7, the V7 chord. The minor IV chord is reharmonized with an ascending-line cliché (m. 9 in the example, but bar 5 in the twelvebar blues form). 


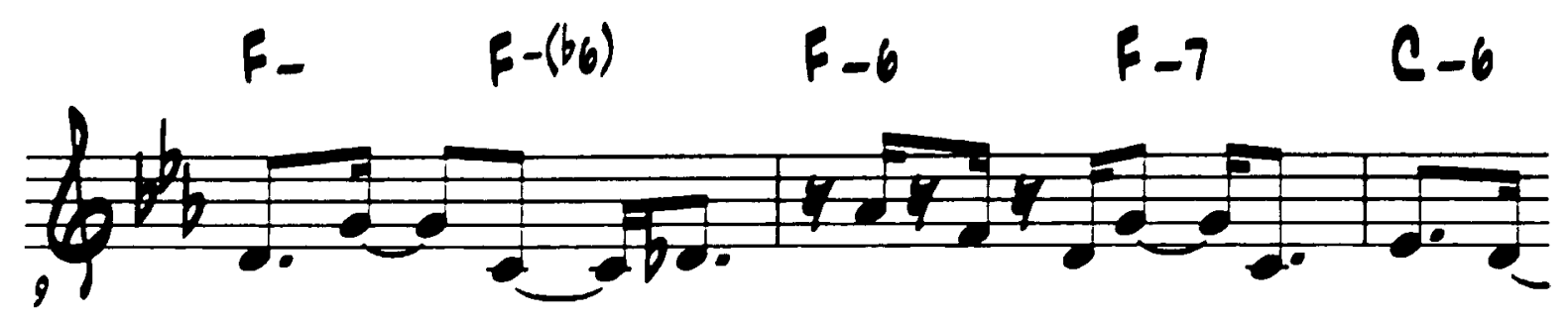

Example 2-1: Sudan, bars 5 and 6 of the blues pattern.

Bars 7 and 8 present a Dominant $7^{\text {th }}$ reharmonization following the $\operatorname{Im} 6$ chord: $\mathrm{Bb} 7(\# 11), \mathrm{Eb} 7(\# 11)$ and D7(Alt). In bar 9 the V/V7 is replaced by AbMaj7 (bVIMaj7); the bVI appears again as an unresolved dominant seventh in the final bar and is the ending chord.

The melodic rhythm has the sixteenth-note pulse characteristic of the Brazilian samba and baiao styles. The first four bars are in the $\mathrm{C}$ dorian mode and the last four are in the $\mathrm{C}$ harmonic minor. The next four bars present the most variation and have the densest harmonic rhythm. Still, with the exception of $\mathrm{Db}$ in bar 5 and $\mathrm{E}$ in bar 7, the passage remains in $\mathrm{C}$-natural minor (natural because the seventh is not present, and the roots and function of the chords suggest $\mathrm{Bb}$ and not $\mathrm{B}$ ).

\section{$\underline{\text { Rhythm }}$}

The feel of this composition is straight sixteenth notes as in a Brazilian samba in 3/4. The rhythm subdivision of the opening bass ostinato is a two-bar pattern (or clave) that accents irregular groups of sixteen notes as follow: $7+7+7+3$, creating an irregular phrasing within the $3 / 4$ pulse. 


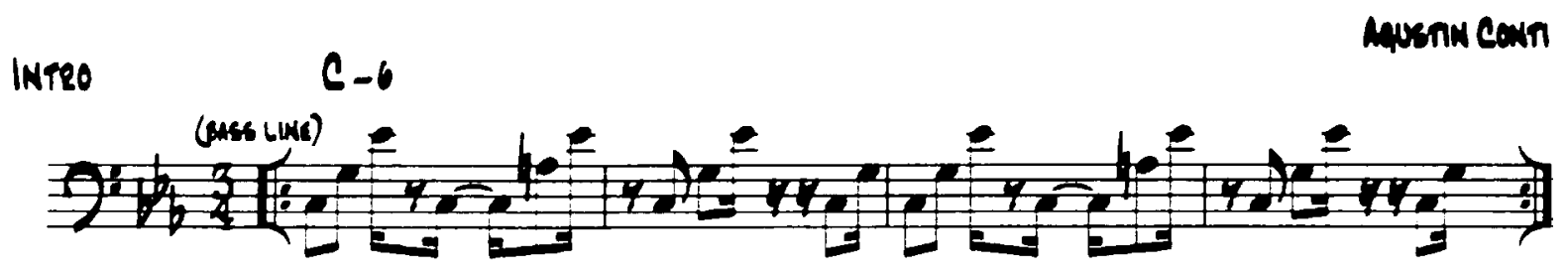

Example 2-2: Sudan, Opening bass ostinato with repeated clave.

The rhythmic bass pattern continues unchanged throughout the harmonic progression that supports the ensuing melodic counterpoint; as a result, some of the perceived chordal roots are rhythmically displaced.

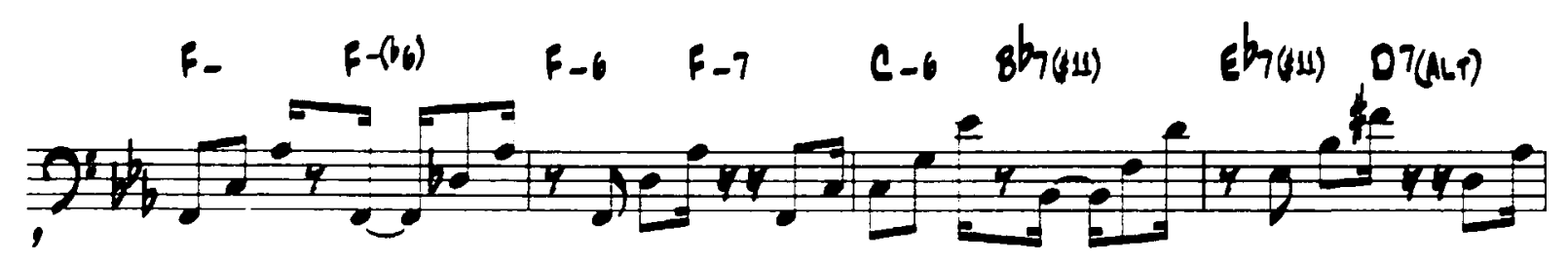

Example 2-3: Sudan, Rhythmic ostinato continuing against the melody.

The melody, particularly in bars $5-9$, where the harmonic rhythm is two chords per bar, suggests a dotted-quarter pulse or $6 / 8$ meter. The comping on piano and drums is open to interact with the melody and bass. ${ }^{12}$ This is of importance during the open solos where the rhythm may drift away from the ostinato figures.

${ }^{12}$ Comping: accompanying an improvised solo in jazz context. 


\section{Chapter III: Analysis of El Immigrante}

This composition was inspired by the CD "Los Argentos" (The Argies) by Argentinean trumpet player/composer Richard Nant. It is dedicated to all legal and illegal immigrants in the United States and to their struggles. It has a circumspect and gloomy character.

\section{Style and Form}

El Immigrante has an $\mathrm{ABACD}$ form where $\mathrm{D}$ is the open solo section. It contains strong references to the Chacarera and Milonga styles. After the solos, the melody is restated as $\mathrm{BA}$. The $\mathrm{C}$ section is a three-part counterpoint inspired by Tango variations. The Solo section D recalls B but in the major mode. The A and C sections are in 15/8, and the $\mathrm{B}$ and $\mathrm{D}$ are in a contrasting $9 / 8$.

\section{Harmony and Melody}

The introductory bass pattern is constructed on A harmonic minor.

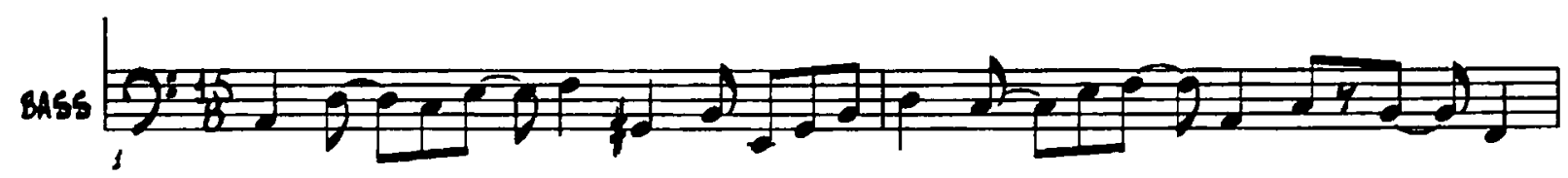

Example 3-1: El Immigrante, introductory bass pattern.

The first chord in the A section clearly implied A harmonic minor, but the next two could be also imply A natural minor; the melody on this section does not contain the 
seventh ( $G$ or $G \#)$ creating ambiguity. After a short modal shift to $\mathrm{Gm}$, A minor returns via Dm7 (IVm) and FMaj7 (bVIMaj7), both possible chords from the A harmonic minor or natural minor scale.

The B section starts in Fm, the same root with which the A Section ended (FMaj7). ${ }^{13}$ This section is mostly built on an F pedal. The first harmonic phrase resolves to E-b6 (C Major) and the second to CMaj\#5, anticipating the movement back to A harmonic minor in the following A section.

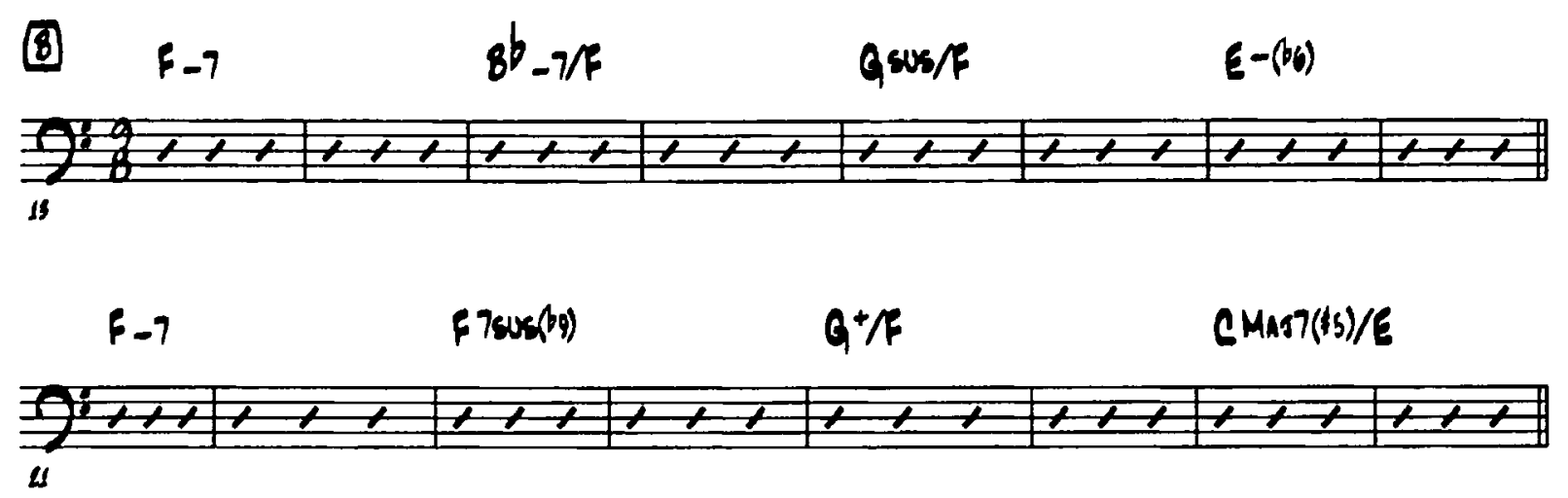

Example 3-2: El Immigrante, B section harmonic movement.

The melody in the tenor sax goes to the lower octave and presents a new idea centering on $G$ (the seventh missing on the A section).

The $\mathrm{C}$ section is arranged in three parts and presents a new idea. The two-bar motif is played by the bass and followed by the piano and tenor sax. It is constructed on F Lydian and Gb Lydian, a reference to the earlier parallel key movement from A to B.

\footnotetext{
${ }^{13}$ This is common practice in Tango forms, where the songs usually modulate to the parallel key in the B section.
} 
()

6.8.

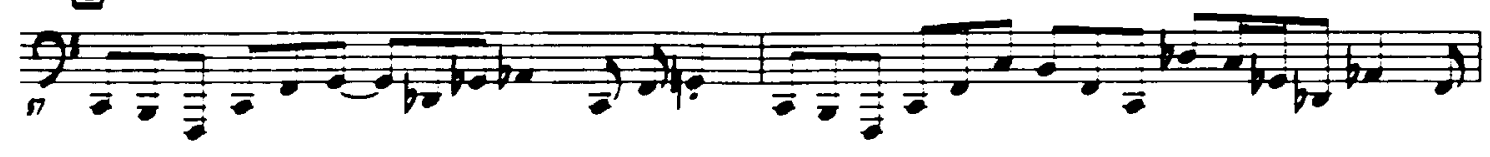

Pus.

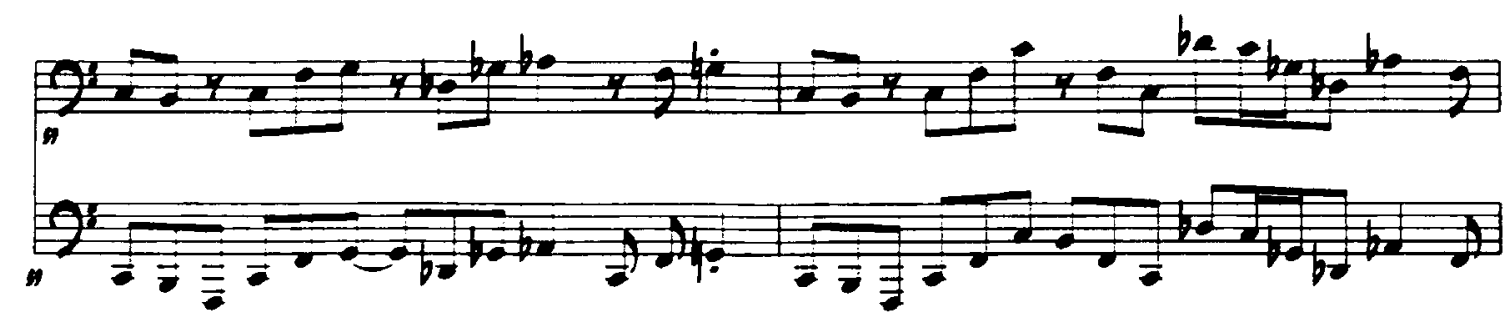

E.8.

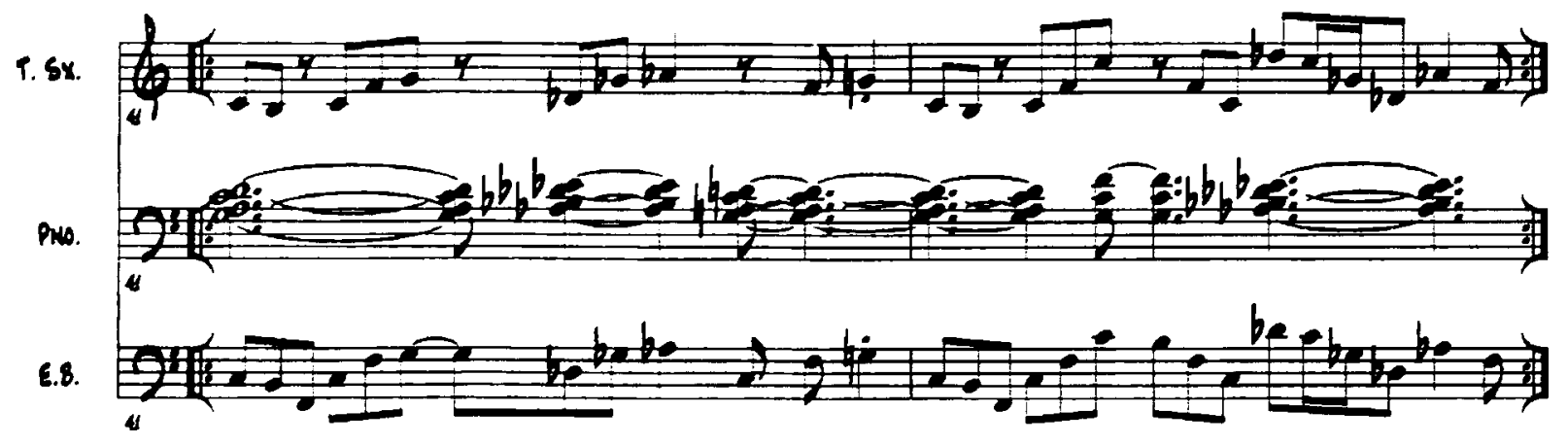

Example 3-3: El Immigrante, first eight bars of C section.

The bass carries the motif against two independent melodies in the piano and sax through four modulations to $\mathrm{Ab}, \mathrm{A}, \mathrm{Bb}$, and $\mathrm{B}$ Lydian before ending on a dramatic $\mathrm{B} 7 \mathrm{Alt}$ chord. The following example illustrates the last 3 modulations. 

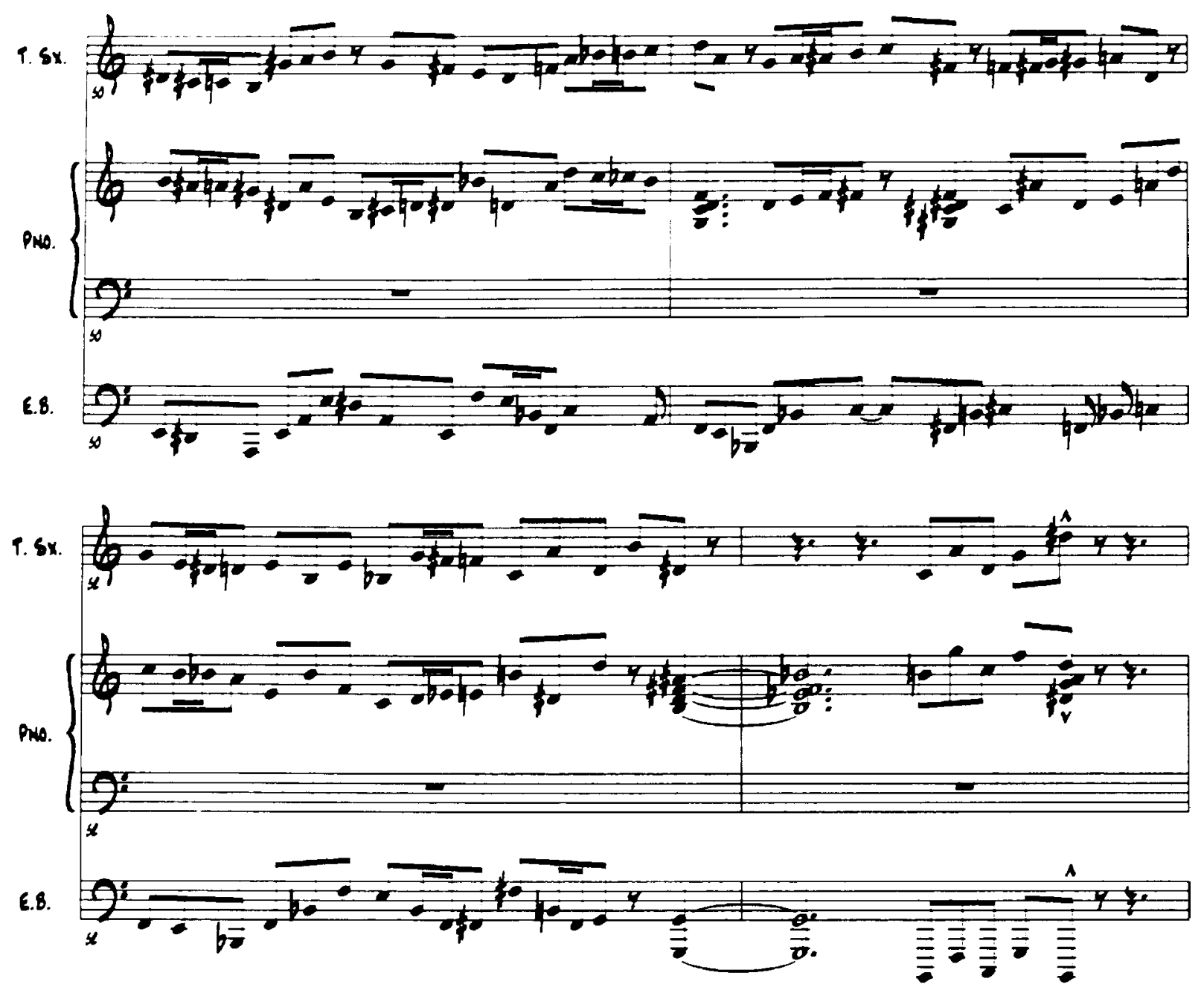

Example 3-4: El Immigrante, last four bars of $\mathrm{C}$ section.

Rhythm

This piece has two distinct rhythmic pulses in dotted quarter notes: the $\mathrm{A}$ and $\mathrm{C}$ sections are in $15 / 8$, suggesting a slow five beat pulse, and the B and D sections are in $9 / 8$ (a slow three beat pulse). The bass patterns constructed are strongly influenced by milonga in A and C, and chacarera in B and D with the bouncy feel usually associated to 12/8. 
The $\mathrm{C}$ section tries to capture the rhythmic feel of the tango variations played by the bandoneon. ${ }^{14}$

${ }^{14}$ Variation: the presentation of the theme in rhythmic figuration, usually in sixteenth notes, that appears in the final section of many instrumental tangos. 


\section{Chapter IV: Analysis of Tangram}

This composition is inspired by jazz legend Michael Brecker. The title refers to the ancient Chinese puzzle game composed of seven pieces, or tans, which are put together to form shapes.

\section{Style and Form}

Tangram is a fast-paced, straight-eighth-note composition that presents an $\mathrm{ABABCAB}$ form, where $\mathrm{C}$ is a contrasting section in half-time, with a $12 / 8$ chacarera feel. The solo section is based on a modified BBDA form; after the drums solo the melody is restated as $\mathrm{AB}$.

\section{Harmony and Melody}

The opening piano-bass unison pattern is based on a D7 (b9) chord (auxiliary diminished scale) with an A7 (Alt) turnaround on the last three beats of the phrase. 

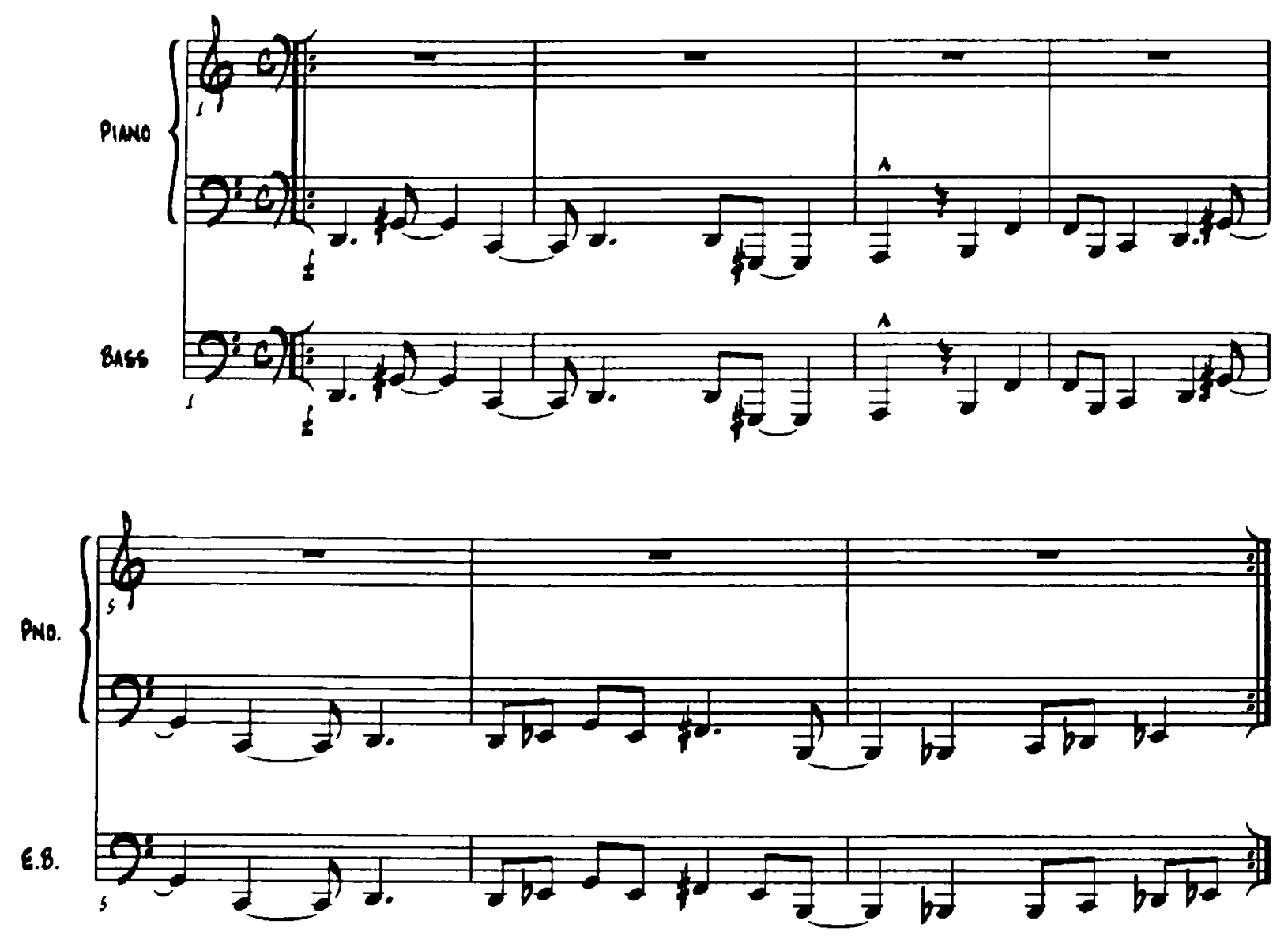

Example 4-1: Tangram, opening piano-bass unison pattern.

The A section is dense, fast-moving, and through-composed. The opening phrase outlines three diminished triads: $\mathrm{Db}^{\circ}, \mathrm{G}^{\circ}$ and $\mathrm{Ab}{ }^{\circ}$ harmonized with dominant chords and a minor chord. After the second phrase is resolved with a quick A Lydian chord, the ending note $\mathrm{Bb}$, the $\mathrm{b} 13$ on the $\mathrm{D} 7$ (Alt) chord, becomes the root of the next section.

The B section is based on the opening D7 (b9) pattern transposed a major $3^{\text {rd }}$ down to $\mathrm{Bb} 7$ (b9). The melody is constructed on the $\mathrm{Bb}$ auxiliary diminished scale. The contrasting $\mathrm{C}$ section has a $\mathrm{G}$ pedal and is centered on $\mathrm{Eb}$ Lydian.

The open solo section introduces a new set of chords. 


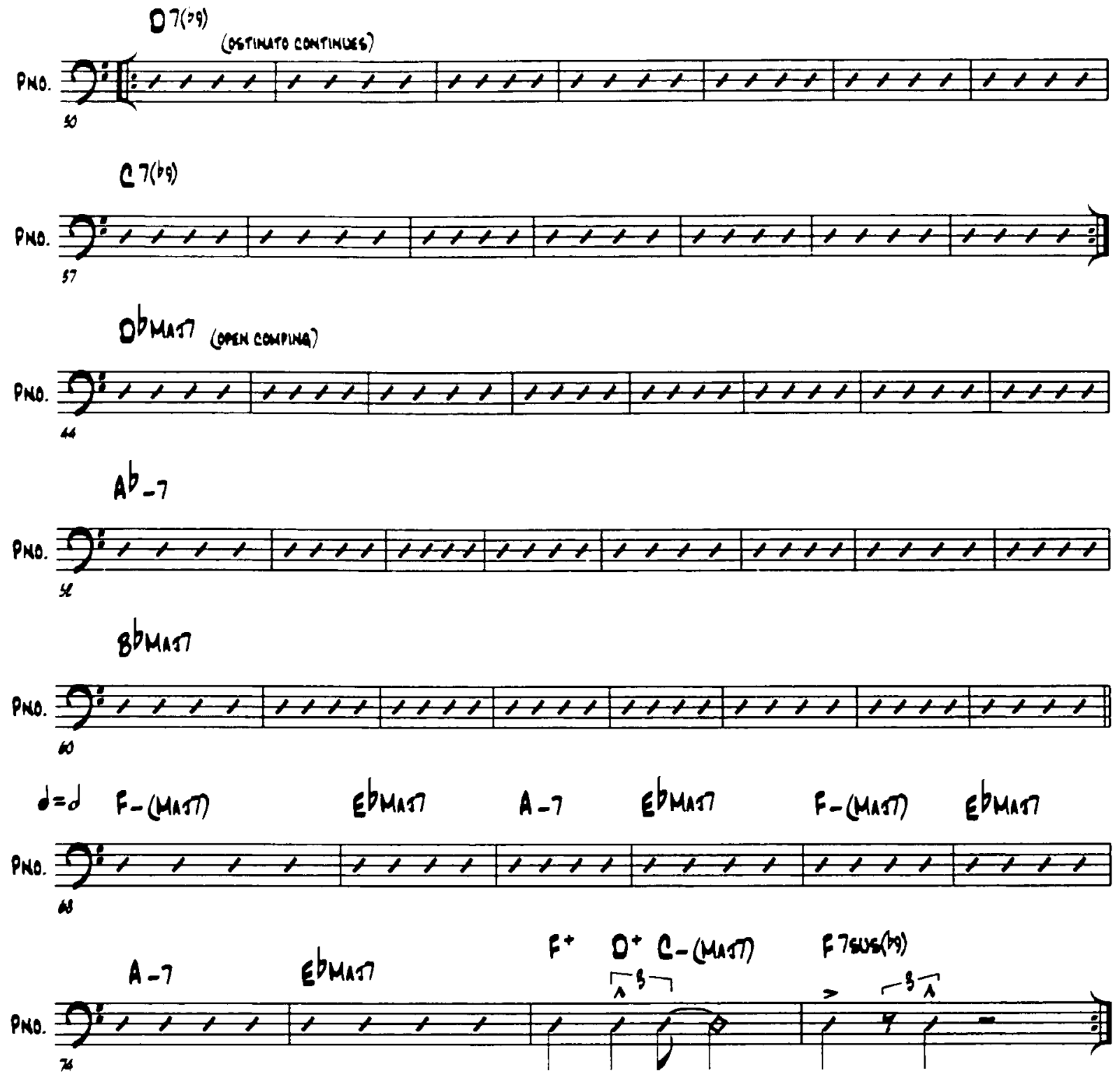

Example 4-2: Tangram, solo form.

Rhythm

The main rhythmic ostinato is played by the piano and bass throughout the different sections of the piece; it is constructed as a four-bar pattern in a 7/4 meter, but it is notated as a seven-bar phrase in $4 / 4$ meter. The A section is entirely a kick section, with no steady pulse on the drums, that also accompany the sax melody. 

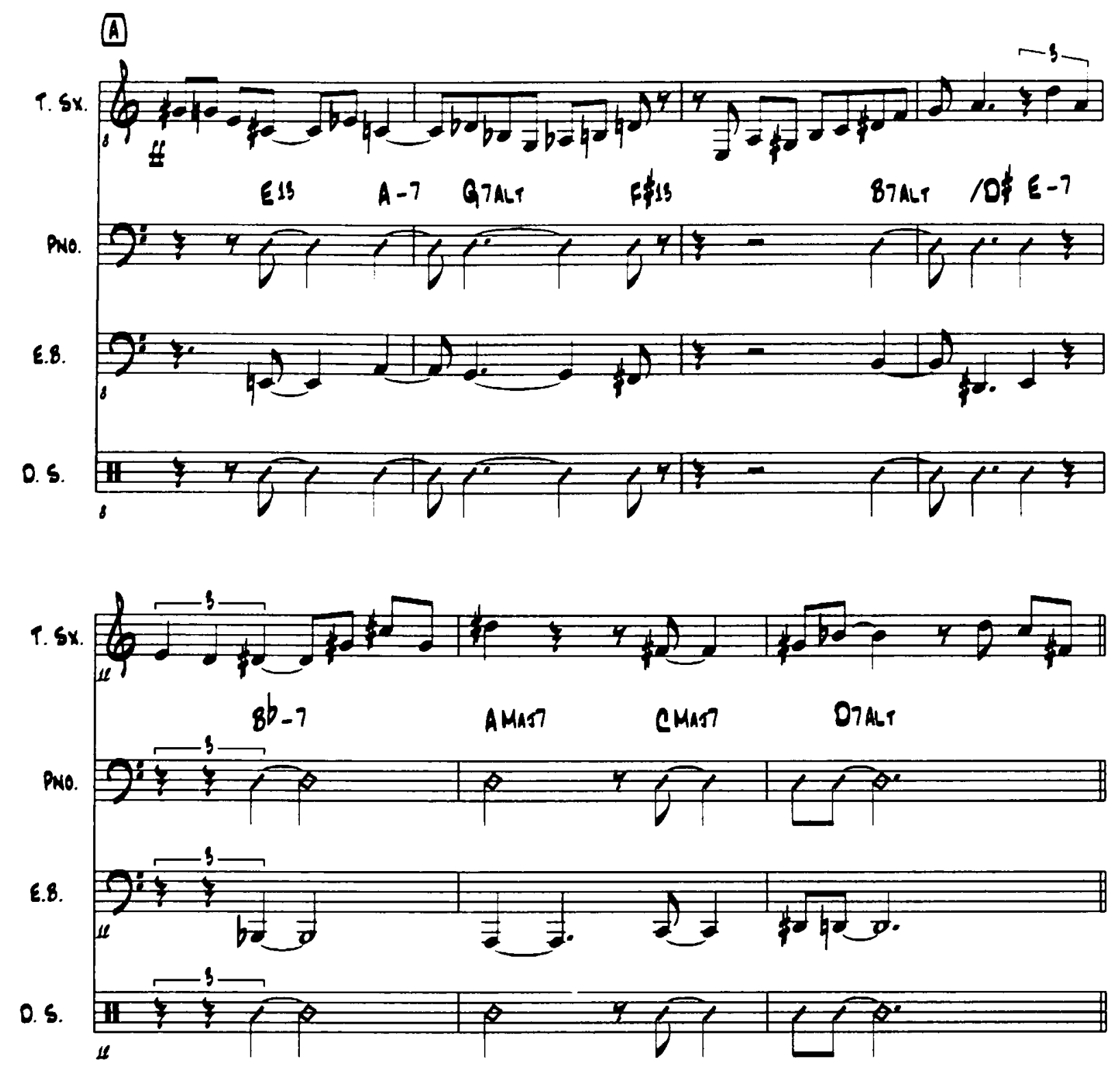

Example 4-3: Tangram, A section.

The contrasting, half-time $\mathrm{C}$ section has a $12 / 8$ chacarera feel propelled by the static $G$ pedal on the bass. The open drums solo is over the bass ostinato. 


\section{Chapter V: Analysis of Katurga}

Katurga is a slow chacarera dedicated to my niece Catalina. The inspiration to write this tune came after listening to the $\mathrm{CD}$ Provinciano by bassist/composer Fernando Huergo. ${ }^{15}$ It has a clear, translucent and well-lit happy mood.

\section{Style and Form}

Katurga has an $\mathrm{ABCD}$ through-composed form. It opens with a rubato prelude section in which the bass states the melody accompanied by piano, after which a piano pattern introduces the slow groove. The bass maintains the melody through the B section. The solo section is in $\mathrm{ABCD}$ form, as well as the recapitulation.

\section{Harmony and Melody}

The piece starts with a twenty-four-bar rubato section that functions as a prelude, with its own independent theme. It begins on $\mathrm{Db}$ Major and ends on $\mathrm{F}$ major. The introductory chords descend chromatically from $\mathrm{Abm} 7$, setting the groove for the A section.

\footnotetext{
${ }^{15}$ The title Provinciano refers to the people of the provinces (states) in Argentina.
} 


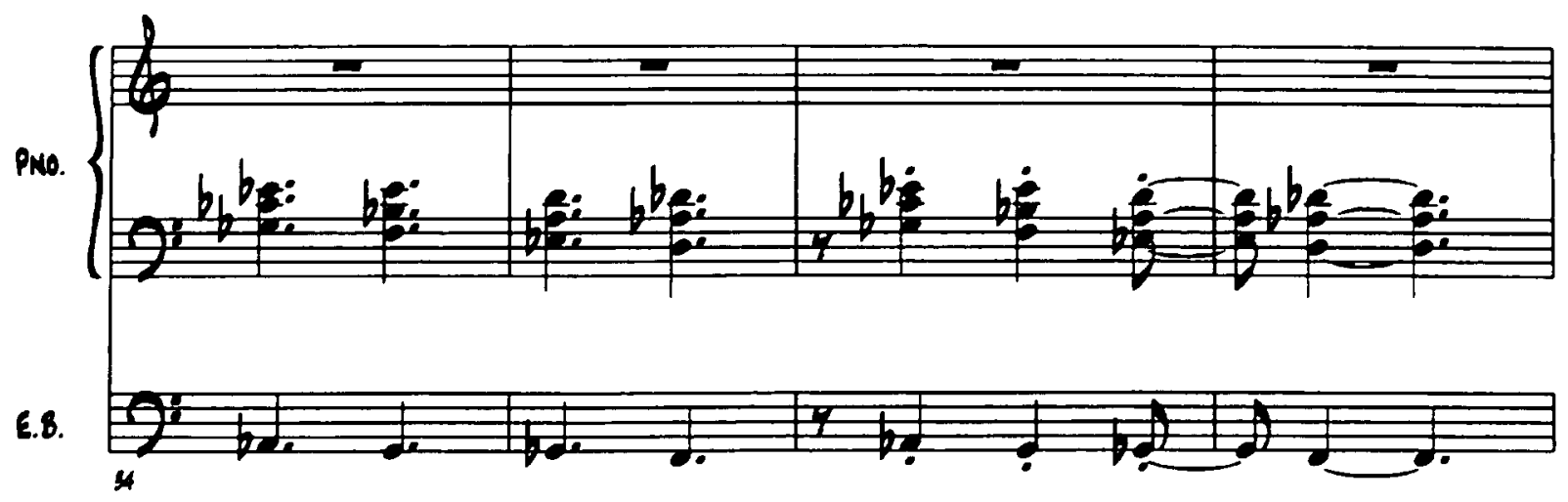

Example 5-1: Katurga, introductory chords.

The A and B sections are sixteen and eighteen bars long, respectively, in which the melody is played by the bass. The A section starts with a G7sus4 chord and, after a series of major II-V progressions through the B section, it resolves to a BMaj7\#5. The C section presents alternating Major7th and Altered dominant chords. The harmonic progression in mm. 1-4 of the D section transposes that in mm. 1-4 of the C section down a half step, but now the progression supports a completely unrelated melodic idea: 


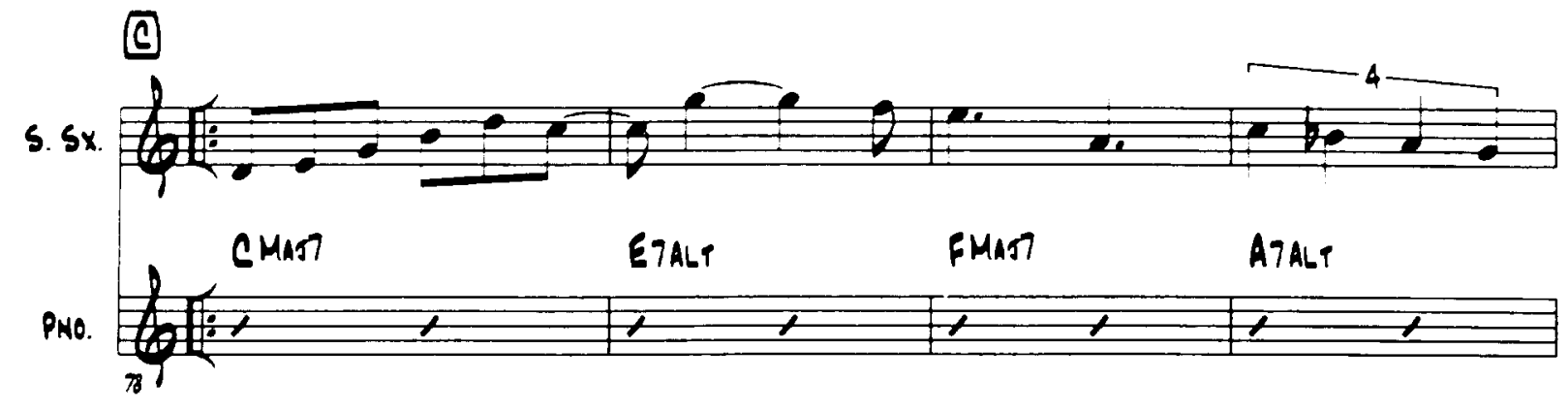

(อ)

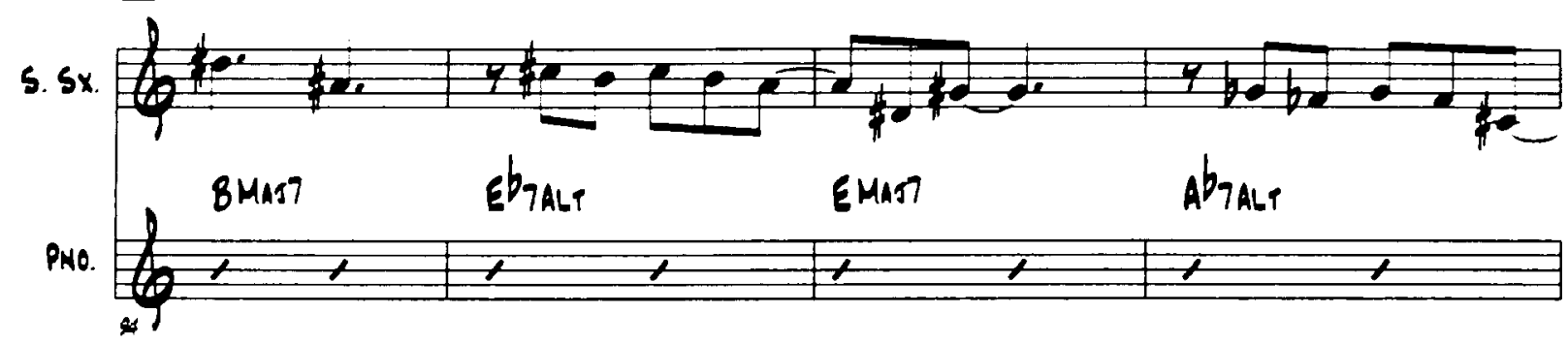

Example 5-2: Katurga, mm. 1-4 of C and D sections.

Rhythm

The rhythm of Katurga is based on a slow steady chacarera groove; the melodic rhythm varies from $6 / 8$ to $3 / 4$ and uses quadruplets. The most distinctive figure of this piece is presented on the introductory chords (see example 5-1). 


\section{Chapter VI: Analysis of Omotesando}

This composition was inspired by the works of the Argentinean classical composer Alberto Ginastera. The title of the piece is the name of a street in Tokyo, Japan; in Spanish, it also refers to any hypothetical present verb or action, from the gerund forms ando and iendo.

\section{Style and Form}

Omotesando is a mid-tempo chacarera piece based on a strong, odd, mixed-meter groove. It has an ABDC form. The A section is made up of odd metric patterns, and the $\mathrm{B}$ is a long, three-part, through-composed section with a $6 / 8$ malambo feel. After a fourbar piano interlude, the six-bar $C$ and seven-bar D sections are presented in 5/4; these sections counterbalance the weight of the strong A section. The open solo section is an $\mathrm{AAB}$ form. After the solos, sections $\mathrm{C}$ and $\mathrm{D}$ are played before returning to the main theme (the initial $\mathrm{AB}$ ).

\section{Harmony and Melody}

The introductory A section's groove is constructed on a piano voicing that suggests E7(\#11), E Phrygian, and FMaj7(\#5). The bass line, however, remains in E Phrygian throughout, creating a tonal ambiguity that complements the unstable nature of the odd, mixed-meter groove. 


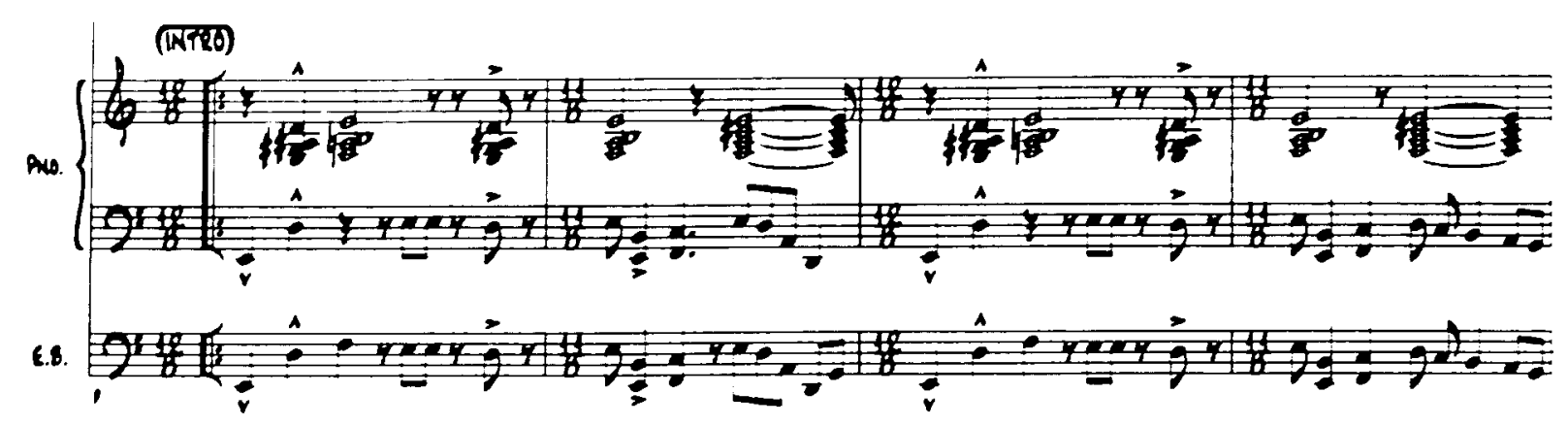

Example 6-1: Omotesando, main groove.

The melodic construction of the A section, like that of the bass, is in E Phrygian. The minor third of the mode, G, only appears briefly on this 8-bar section.

The $\mathrm{B}$ section is divided into three parts of sixteen, sixteen, and eight bars, respectively, with no particular mode or tonal center defined. The presence of minor seventh chords, many of them on the first beat of a four-bar group, gives a shifting, minor modal quality. See example 6-2.

The melody does not favor any particular minor mode on these minor chords. The main motif: $\mathrm{G} \#-\mathrm{F} \#-\mathrm{G} \#-\mathrm{E}$ is developed in the first sixteen bars. A new idea starts in section $\mathrm{B} 2$, where a quadruplet figure predominates. The melodic curve climaxes at measure 47 with a sustained $\mathrm{Bb}$ above the staff over the Ebm(Maj7) chord that occurs three bars after the middle of the big B section. See example 6-3. 

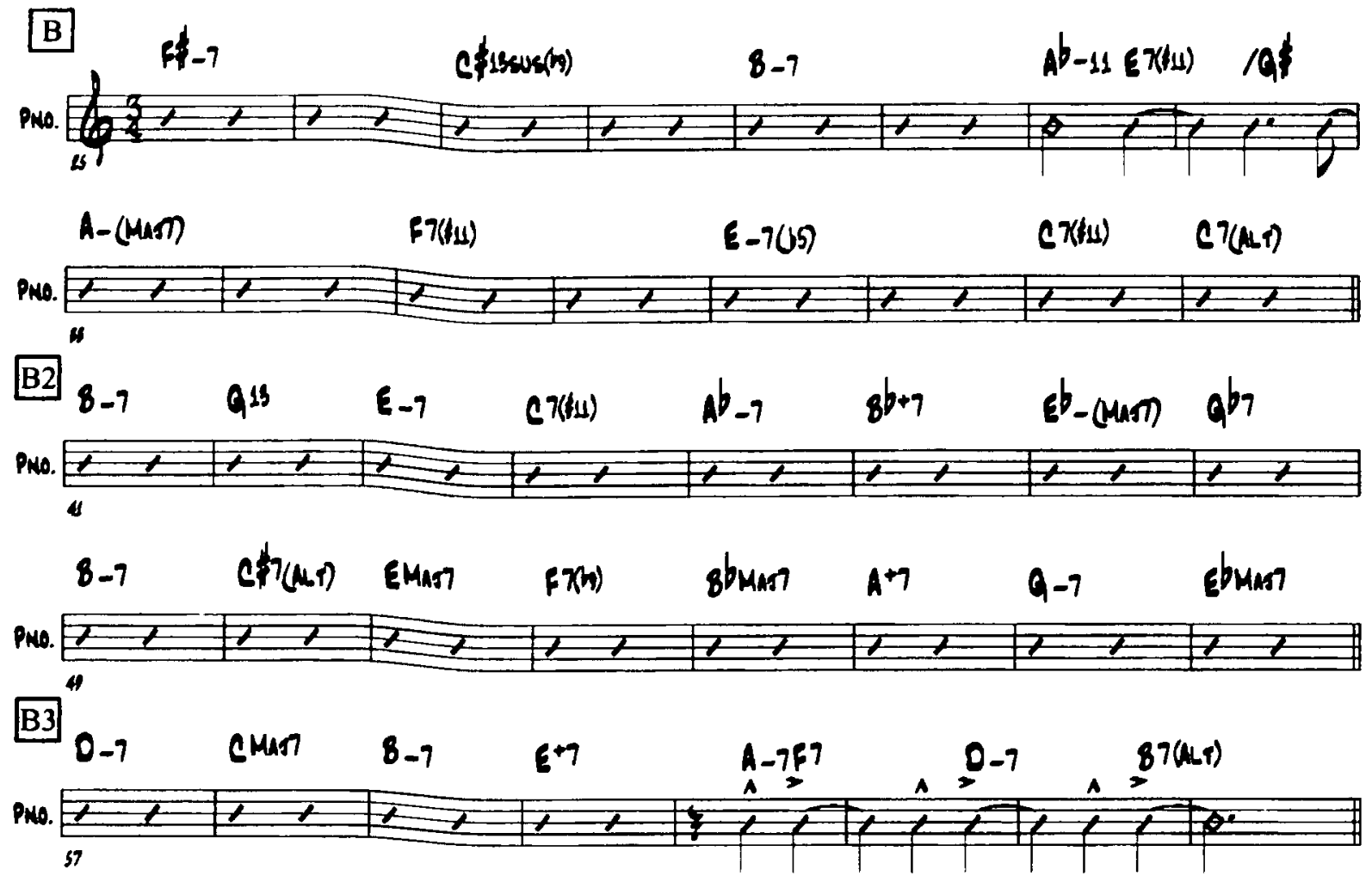

Example 6-2: Omotesando, B section harmonic movement.

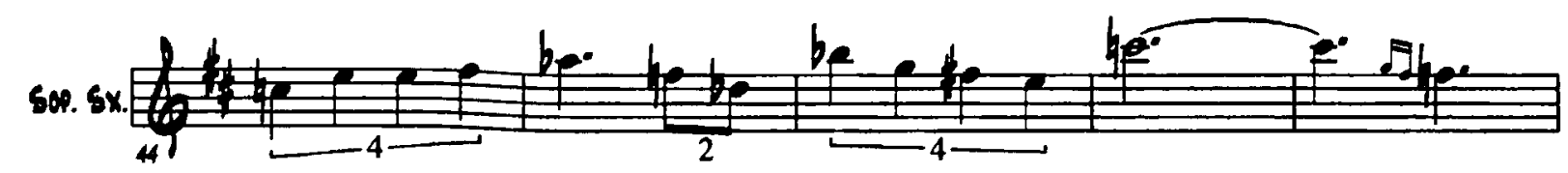

Example 6-3: Omotesando, melodic climax at measure 47.

The first interlude, the $\mathrm{C}$ and $\mathrm{D}$ sections, and the second interlude are constructed on a sus2 pedal grip in the right hand; the left hands plays fifths, suggesting Db Lydian, $\mathrm{Eb7}$, Bbm6, and C Phrygian—all diatonic chords derived from the parent scale Ab Major. 


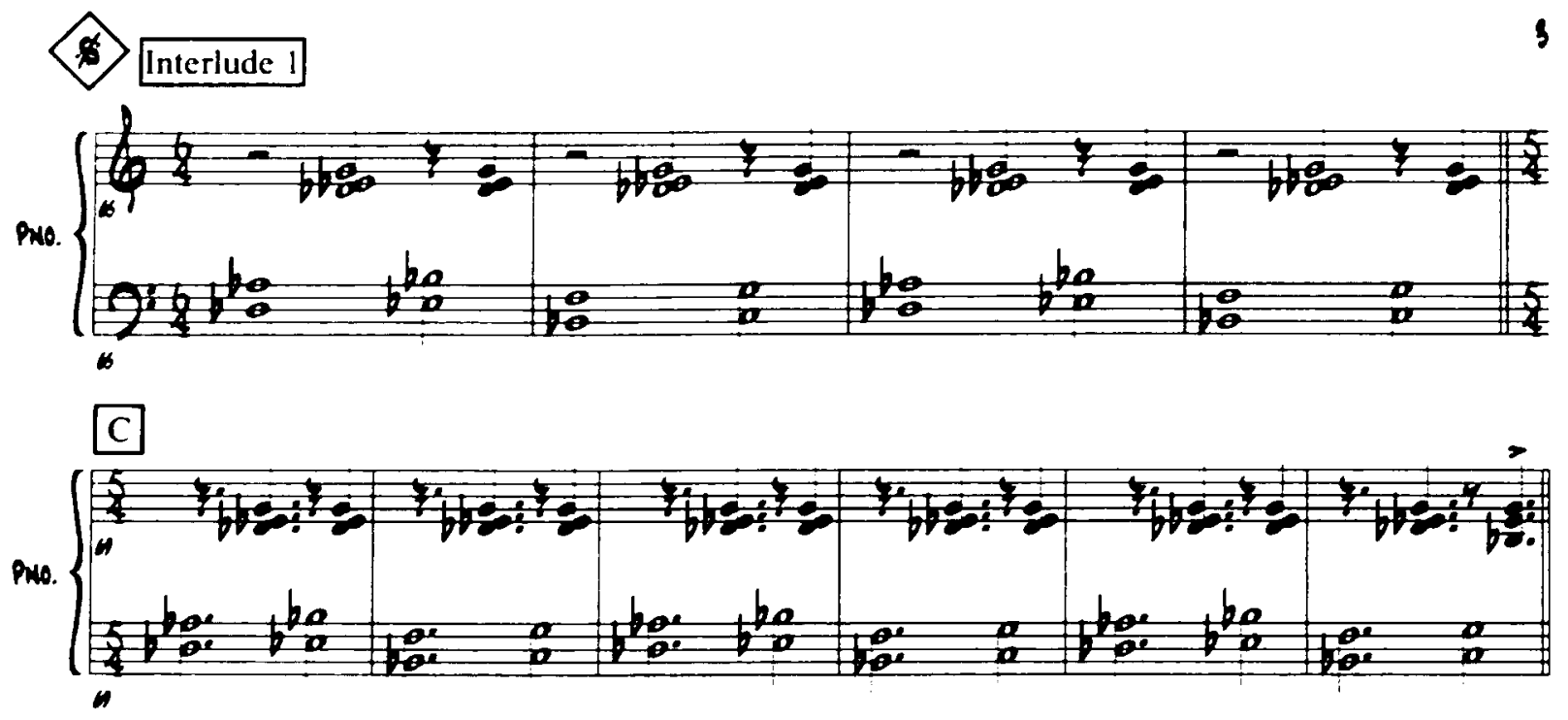

Example 6-4: Omotesando, interlude 1 and $\mathrm{C}$ section, piano part.

Rhythm

The odd-meter construction of the main groove is perhaps the strongest and most distinct element of this composition. The basic dotted-quarter note pulse of the chacarera is truncated by the alternation of $12 / 8$ and $11 / 8$. This alternation is repeated three times in that order; the fourth time, $10 / 8$ (performed as 5/4) replaces the expected $11 / 8$ in the second bar of the pattern.

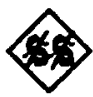

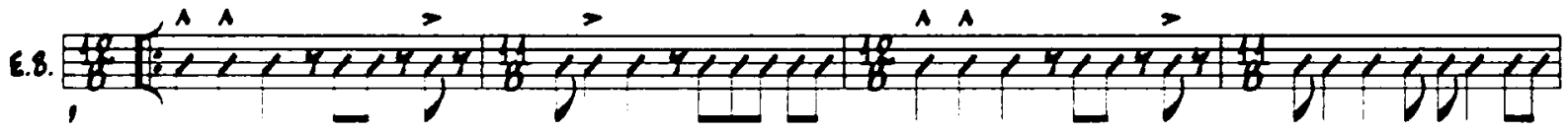

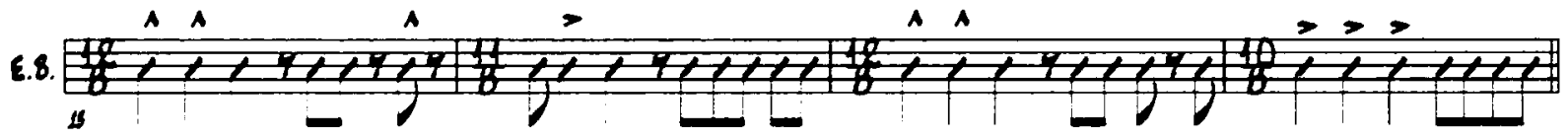

Example 6-5: Omotesando, rhythmic figures of bass line. 
The entire $B$ section is played in $6 / 8$, but the melody is written in $3 / 4$ to facilitate the reading and comprehension. Although the $\mathrm{C}$ and $\mathrm{D}$ sections are in 5/4, another meter change, the entire composition should sound as an organic entity, with a natural, flowing rhythmic feel. 


\section{Chapter VII: Analysis of Fuegos de Manikarnika}

This composition is inspired by the main burning site of the Holy City of Varanasi, India, also called Manikarnika, with its sacred flames that are maintained year round. ${ }^{15}$

\section{Style and Form}

Fuegos de Manikarnika has a through-composed form that can be described as ABA'CDA", followed by an open solo section. The $\mathrm{C}$ section recurs between solos, and the recapitulation involves D and A" only. D has a murga groove, and the solo is based on a candombe groove; both are in half-time.

\section{Harmony and Melody}

The entire initial $\mathrm{ABA}^{\prime}$ is a unison line, with no chord changes supporting it. The A is played by the tenor sax and bass an octave apart. The piano enters in the B section in unison with the tenor sax. In $\mathrm{A}^{\prime}$ the tenor plays an octave higher, thus two octaves above the bass. The drums are free to play the melody in no specific part of the set, in a linear fashion with no steady groove and without fills.

\footnotetext{
${ }^{15}$ Also considered the center of the Hindu universe. See Christopher Justice, Dying the Good Death: The Pilgrimage to Die in India's Holy City (Albany: State University of New York Press, 1997), 56
} 
(1) ELCeresess

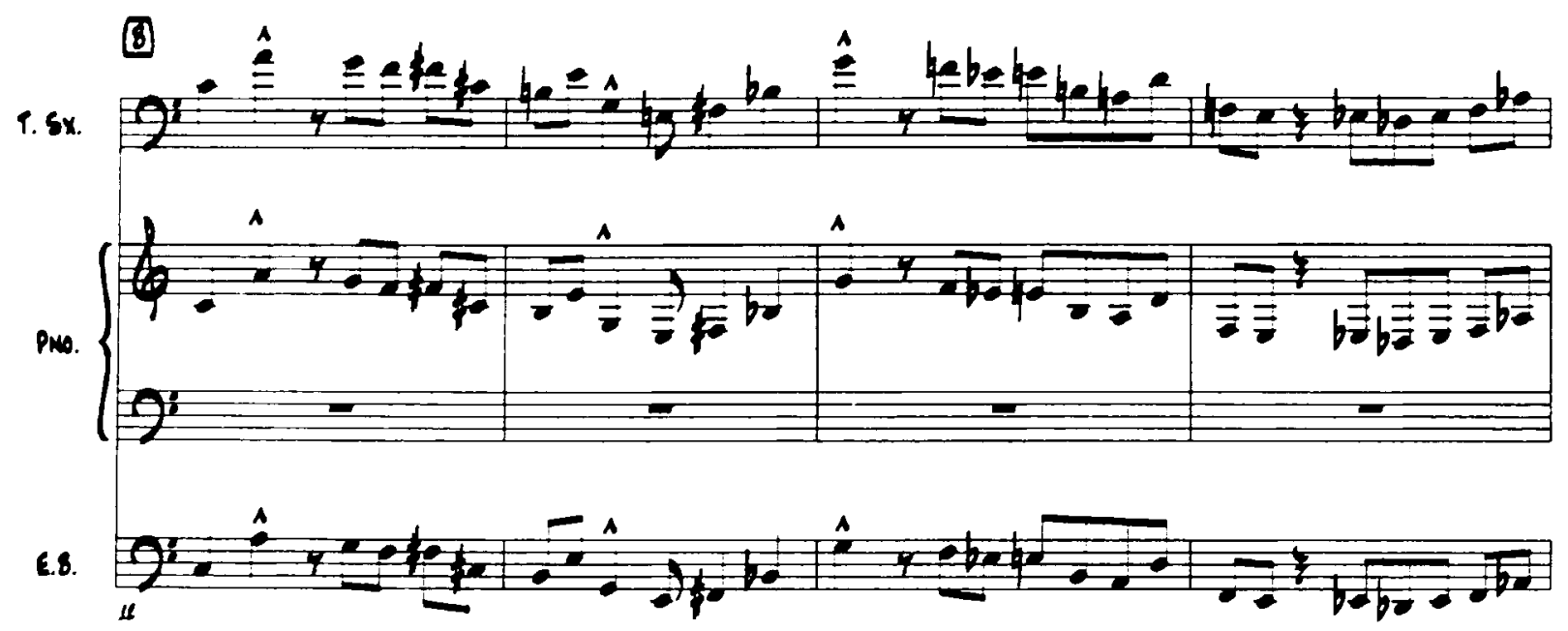

(1)

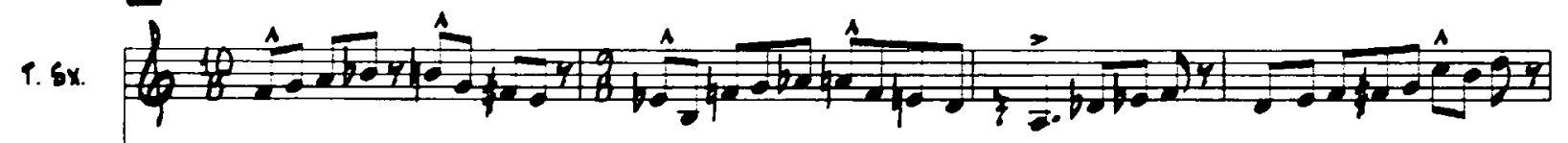

PNo.

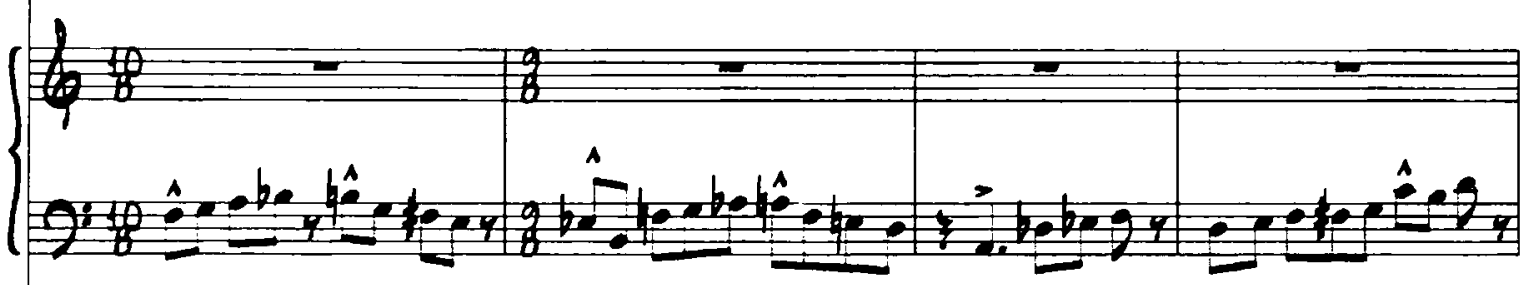

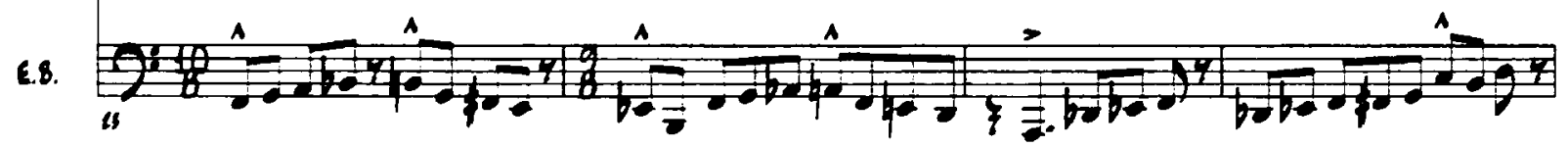

Example 7-1: Fuegos de Manikarnika, first 4 bars of sections A, B and A'. 
The melody is based on the sequence of three descending major and melodic minor modes a half-step apart: $\mathrm{F}$ major and $\mathrm{E}$ melodic minor; $\mathrm{Eb}$ major and $\mathrm{D}$ melodic minor; $\mathrm{Db}$ major and $\mathrm{C}$ melodic minor.

The $\mathrm{C}$ section is based on a $\mathrm{Bb} 7$ (b9) auxiliary diminished pattern with supporting chord changes on the piano.

The $\mathrm{D}$ section is a murga groove in half time with an F pedal on the bass, no melody part and a drifting minor modal quality provided by triads on the piano.

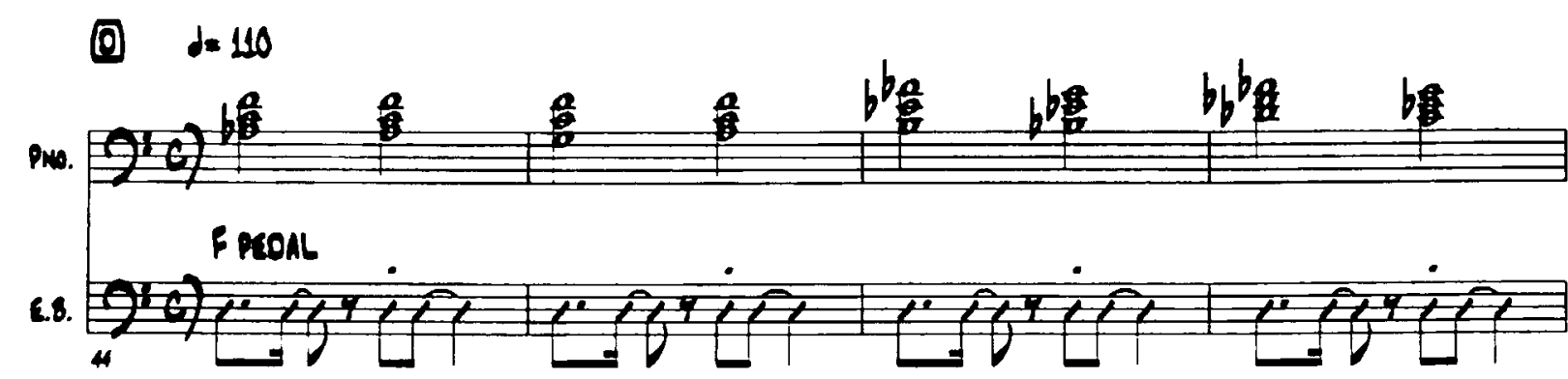

Puis.

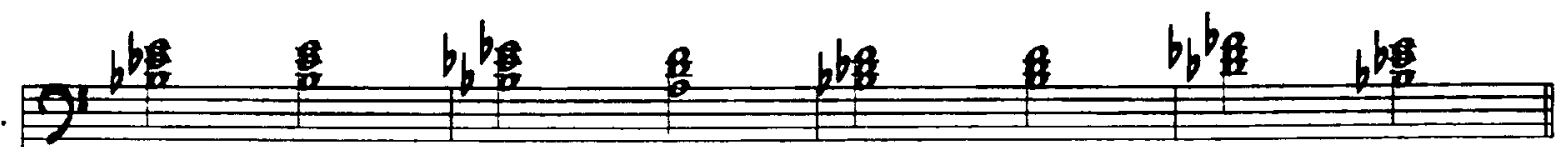

6.8

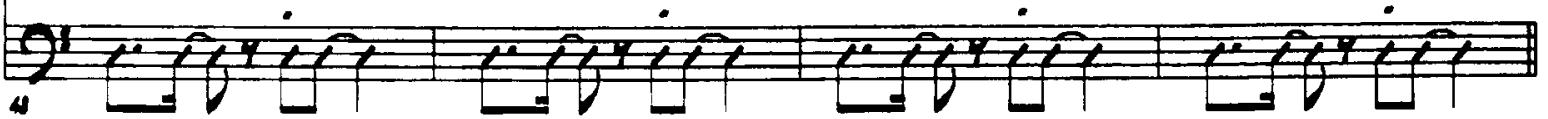

Example 7-2: Fuegos de Manikarnika, D section.

The solo section (E) presents a more standard set of chord changes with a preponderance of $\mathrm{Dm} 7$ and $\mathrm{Bbm} 7$ Chords 
$\underline{\text { Rhythm }}$

The $\mathrm{ABA}^{\prime}$ and $\mathrm{C}$ sections remain almost entirely in 9/8, apart from some exceptional 10/9 bars. Until C, the intended effect is that of complete unison, including the drums that play the melody with no steady groove until the D section's half-time murga in $4 / 4$

The solo section is in candombe style and, like $D$, is in half-time $4 / 4$, providing a sense of relief from and contrast with the irregular meter of the other sections. 


\section{BIBLIOGRAPHY}

Abram, David, Nick Edwards, Mike Ford, Devdan Sen and Beth Wooldridge. The Rough Guide to India. 6th ed. London: Rough Guides, 2005.

Camargo Piedade, Acacio T. "Jazz, Musica Brasilera e Friccao de Musicalidades." Http://tv.ufrj.br/anppom/.http://tv.ufrj.br/anppom/sessao18/acacio_piedade.pdf (5 January 2009)

Corti, Berenice. "Identidad, "Jazz Argentino", Y Van." Http://jazzclub.wordpress.com/. http://jazzclub.files.wordpress.com/2006/10/identidad_jazz_argentino_y_van.pdf (19 January 2009).

Fernandez, Raul A. From Afro-Cuban Rhythms to Latin Jazz. Berkeley \& Los Angeles: University of California Press, 2006.

Fiorio, Ricardo. "La Escritura Bandoneonistica." Http://www.inorg.chem.ethz.ch/tango/band/bandoneon.html. http://www.inorg.chem.ethz.ch/tango/band/fiorio/escritura.html (5 February 2009).

Ginastera, Alberto. 12 American Preludes for Piano. New York: Carl Fisher, 1946.

Guevara, Facundo, and Fernando Martinez. Roots of South America. Sun Valley, Cal.: Big Fish Audio, 1999.

Justice, Christopher. Dying the Good Death: The Pilgrimage to Die in India's Holy City. Albany: State University of New York Press, 1997.

Kostka, Stefan, and Dorothy Payne. Tonal Harmony, with an introduction to twentiethcentury music. 4th ed. Boston: McGraw-Hill, 2000.

Levine, Mark. The Jazz Piano Book. Petaluma, Cal.: Sher Music Co, 1989. . The Jazz Theory Book. Petaluma, Cal.: Sher Music Co, 1995.

Machado, Hugo, Willy Muñoz, and Jorge Sadi. El toque de Candombe, ritmo tradicional afro-uruguayo. Pacific, Mo.: Mel Bay Publications, 2002.

Nicholson, Stuart. Is Jazz Dead? (Or has it moved to a new address). New York: Routledge Taylor \& Francis Group, 2005.

Roberts, John S. The Latin Tinge: The Impact of Latin American Music on the United States. New York: Oxford University Press, 1979. 
Sehinkman, Esteban . "Ejemplos de Ritmos." Http://www.realbookargentina.com.

http://www.realbookargentina.com/extras.php (21 November 2008).

Turabian, Kate. A Manual for Writers of Terms Papers, Theses, and Dissertations. 6th ed. Chicago \& London: The University of Chicago Press, 1996.

Vega, Carlos. Panorama de la Musica Popular Argentina, con un ensayo sobre la ciencia del folklore. Buenos Aires: Editorial Losada, 1944. 


\section{APPENDIX A: GLOSSARY OF STYLES}

\section{Candombe}

Candombe is the most important rhythm in the small, neighboring country of Uruguay. Its strong influence can be heard throughout the Rio de la Plata region, especially in Montevideo and Buenos Aires. It was brought to the region in the eighteenth century by black slaves from Angola, Congo and Mozambique. ${ }^{16} \mathrm{~A}$ dramatic religious dance, the candombe was usually performed and celebrated on January 6, "Dia de Reyes" (The Day of The Three Kings), in order to commemorate the coronation of the Congo kings. Percussionist Hugo "Foca" Machado explains: "The name candombe (or "tangos" which was the name used until 1830) often designated the meeting places where the Africans would congregate, as well as being used in reference to the music and dances performed at these meetings." 17 The rhythmic clave in candombe is known as madera; it is a 3:2 clave pattern like the traditional 3:2 Cuban Son clave. It is played on three AfroUruguayan drums called "Tambores," and it has been adapted here for the drums set and/ or congas.

Example: ${ }^{18}$

\footnotetext{
${ }^{16}$ Guevara Facundo and Fernando Martinez, Roots of South America (Sun Valley, Cal.: Big Fish Audio, 1999), 15

${ }^{17}$ Hugo Machado, Willy Muñoz, and Jorge Sadi, El toque de Candombe, ritmo tradicional afro-uruguayo (Pacific, Mo.: Mel Bay Publications, 2002.

${ }^{18}$ From Esteban Sheinkman, "Ejemplos de Ritmos." Http://www.realbookargentina.com. http://www.realbookargentina.com/extras.php (21 November 2008).
} 


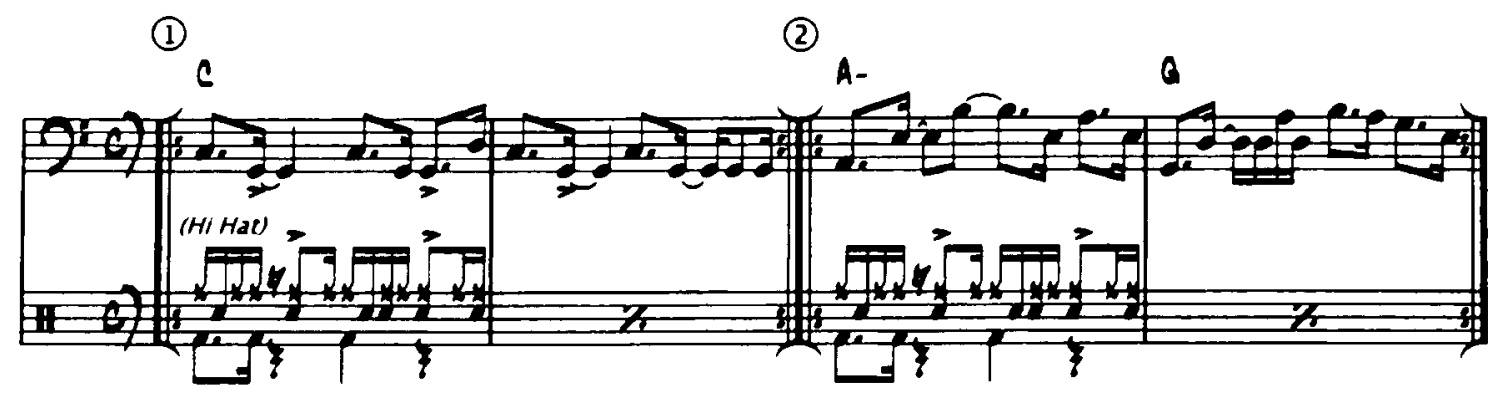

\section{Chacarera}

Originally from the northwest region of Argentina, it is played and danced all over the country. This $6 / 8$ dance was strongly influenced by the zamacueca (Africanrooted music from Peru). The instrumentation generally used is guitars, bombo leguero (wooden bass drum) and voice. ${ }^{19}$ Chacareara is a very popular rhythm in today's Argentinean modern music scene, and it is used by many jazz and fusion groups, who combine its intense polyrhythmic figures with jazz and funk elements.

Example:

Chacarera d. $=120$

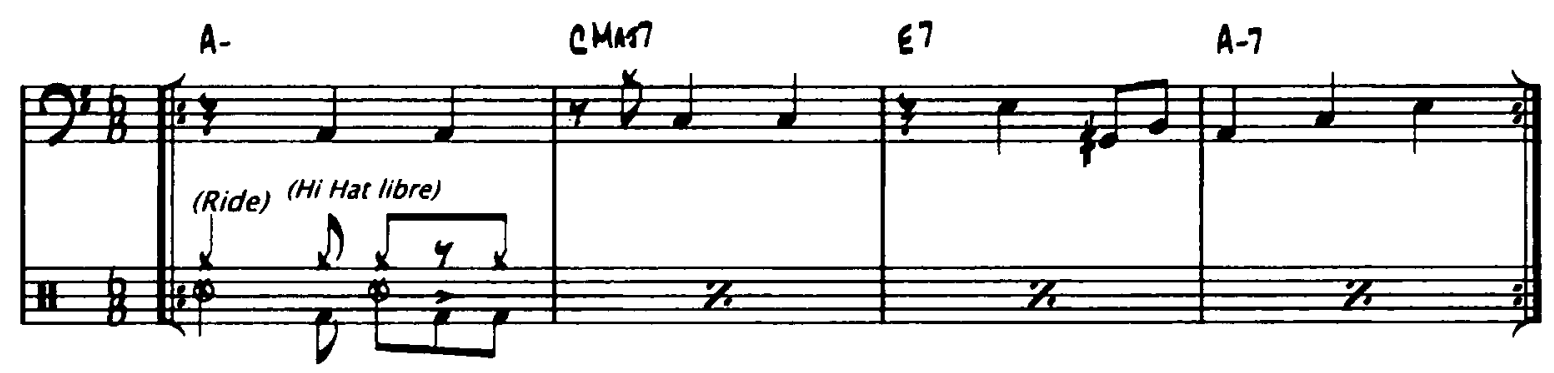

${ }^{19}$ Guevara and Martinez, 17 


\section{Malambo}

Also from the northwest region of Argentina, the malambo resembles the chacarera in instrumentation, rhythmic feel, and popularity; although it differs in so far as it is danced only by males. The dancer (zapateador) challenges the bombo player with his intricate movements and percussive phrases, responding to the drum patterns in dialogue, creating a "drum battle" sound.

\section{Milonga}

From the Rio de la Plata region, it was originally a creation of the troperos (cow hunters) in the second half of the eighteenth century. There are two distinct musical genres, both of which are called milonga. There is the milonga that is part of the tango family, and there is the milonga folklorica, also known as milonga sureña, that is played on guitar and voice. ${ }^{20}$ The term milonga is also used to designate the place where milonga and tango are danced. The milonga/tango is very popular even today and uses traditional tango instrumentation: violins, piano, bandoneon, guitar, and upright bass.

Example:

Milonga

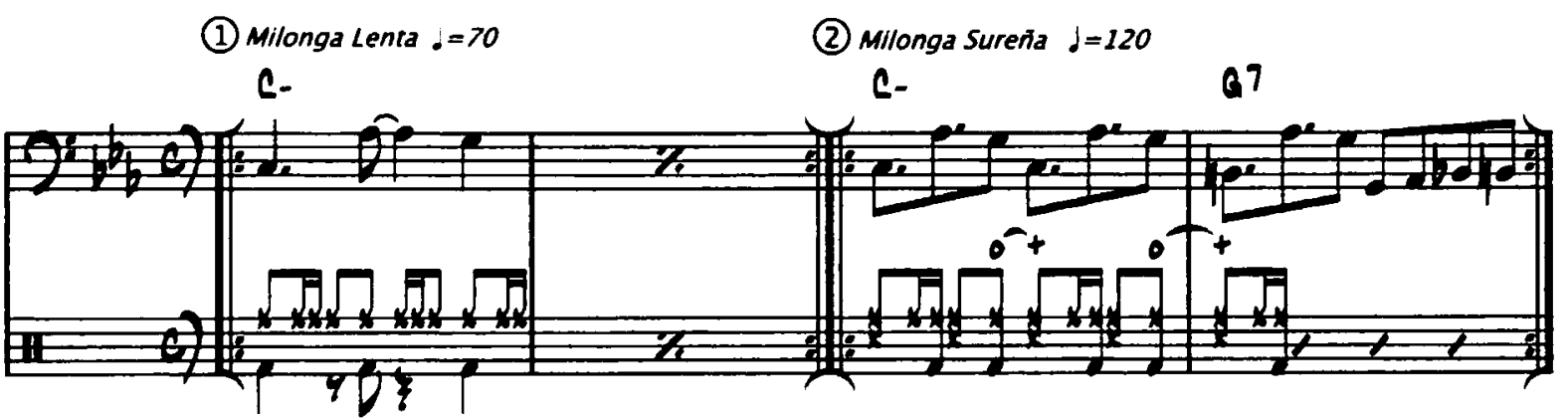

${ }^{20}$ Guevara and Martinez, 17 


\section{Murga}

This dance is the most important social expression of Uruguay. Each union, neighborhood, community and county has its own murga ensemble with its own identity. "They prepare year around to perform in the carnival, much in the same way the "scola do sambas" do in Brazil's carnival." ${ }^{21}$ Murga flourished along both banks of Rio de la Plata. In Buenos Aires, it is called murga porteña to differentiate its origin from its Uruguayan counterpart. The instruments used are the bombo (bass drum), redoblantes (snare drums), and platillos (cymbals). The cambombe groove can also be added to the murga style.

Example:

Murga Uruguaya $d=100$

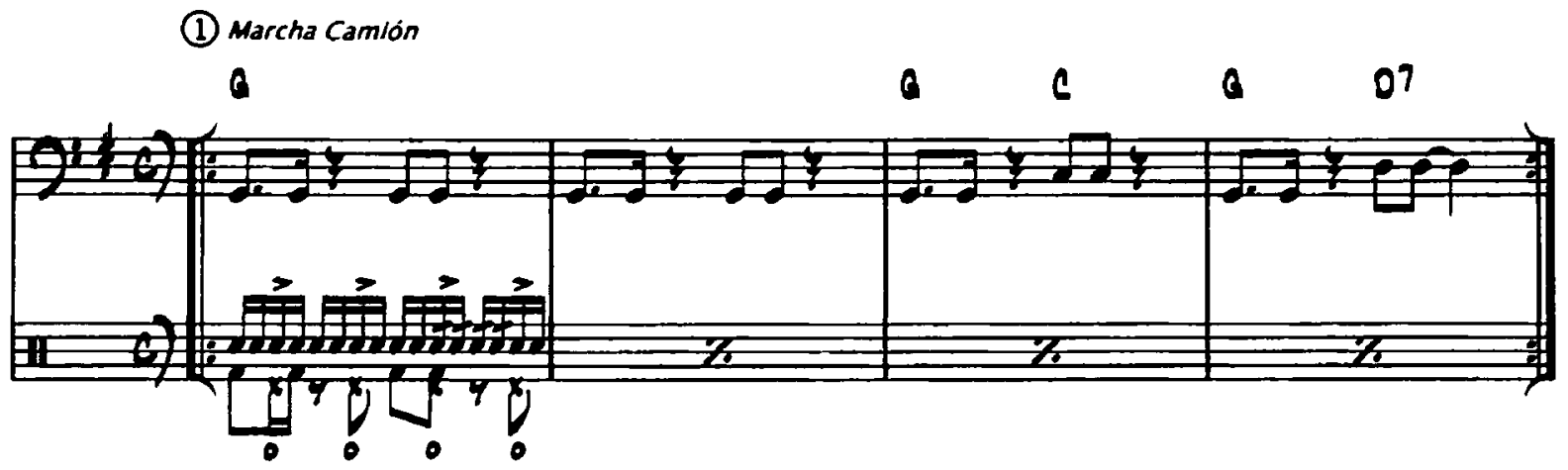

(2) Marcha Acandombada

C-7

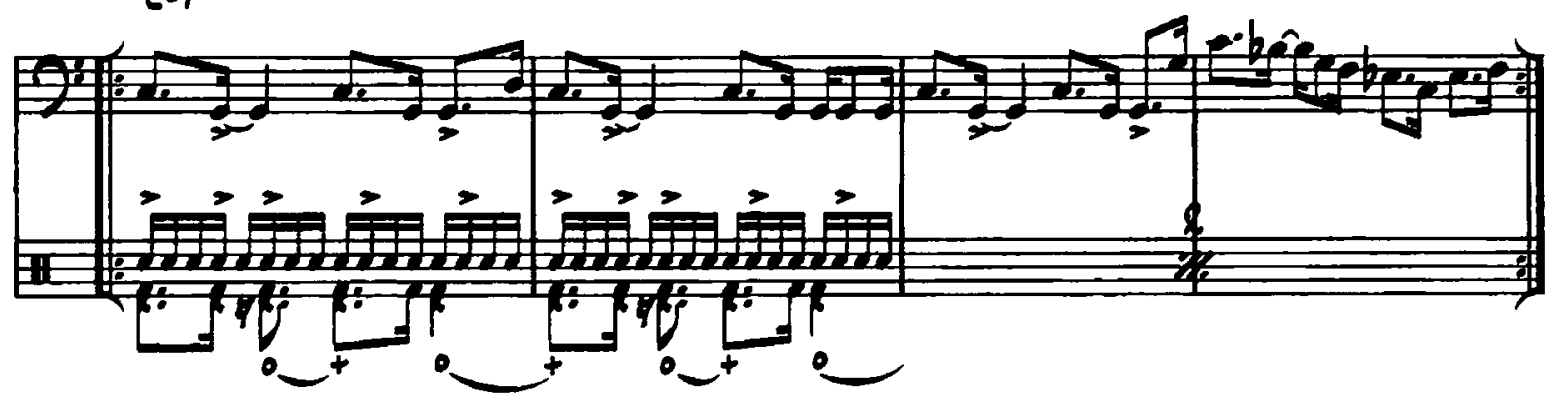

${ }^{21}$ Guevara and Martinez, 15 


\section{APPENDIX B: TRANSCRIPTIONS}

Sudan

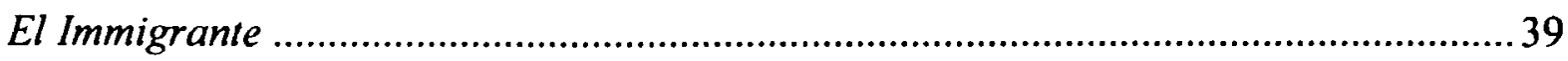

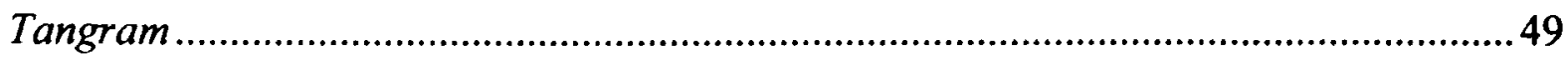

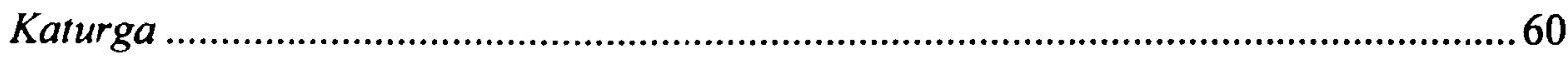

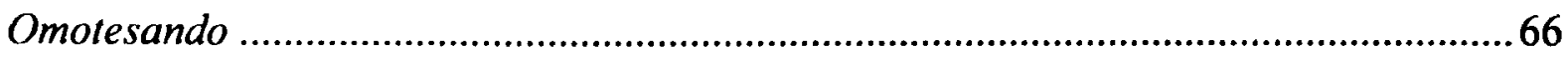

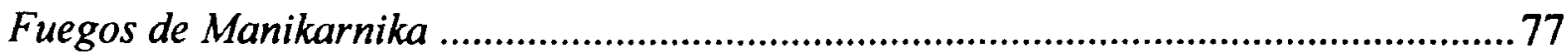


(INFe)

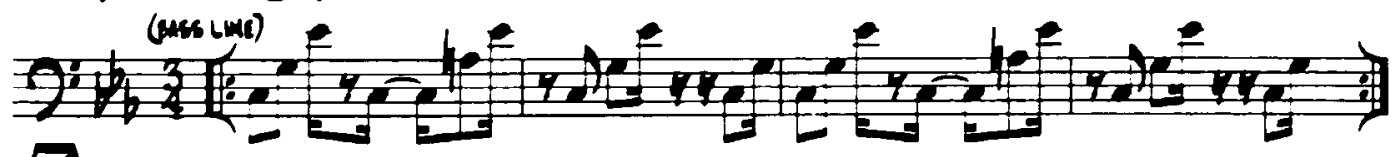

(heno) 8 C-6

$0-7$

c-6

$C 7(\mu r)$

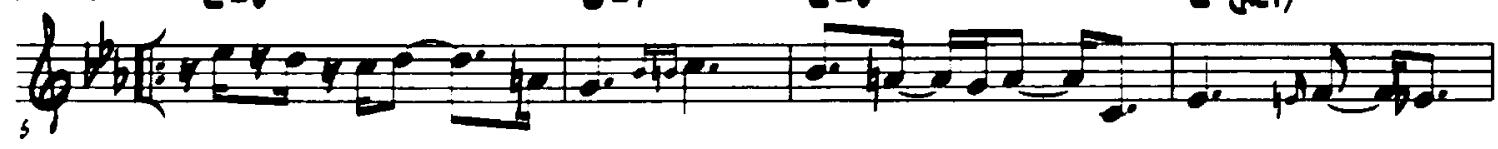

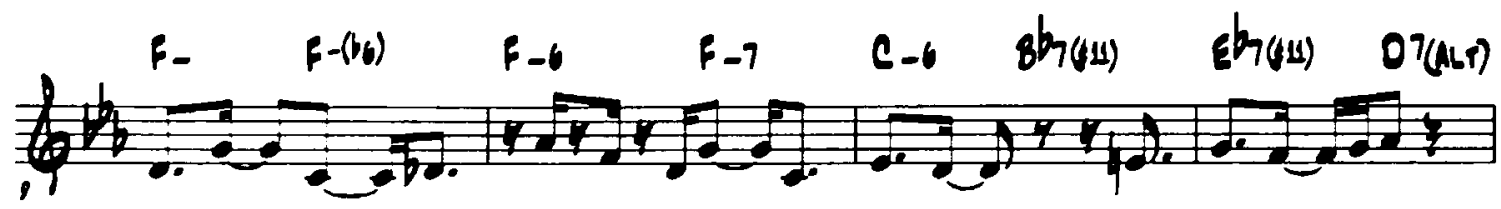

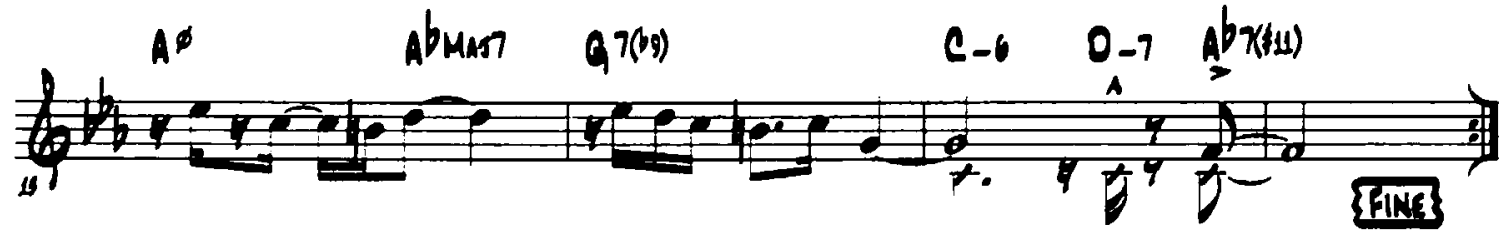

Open (for Ist solo only) on cue to solo section
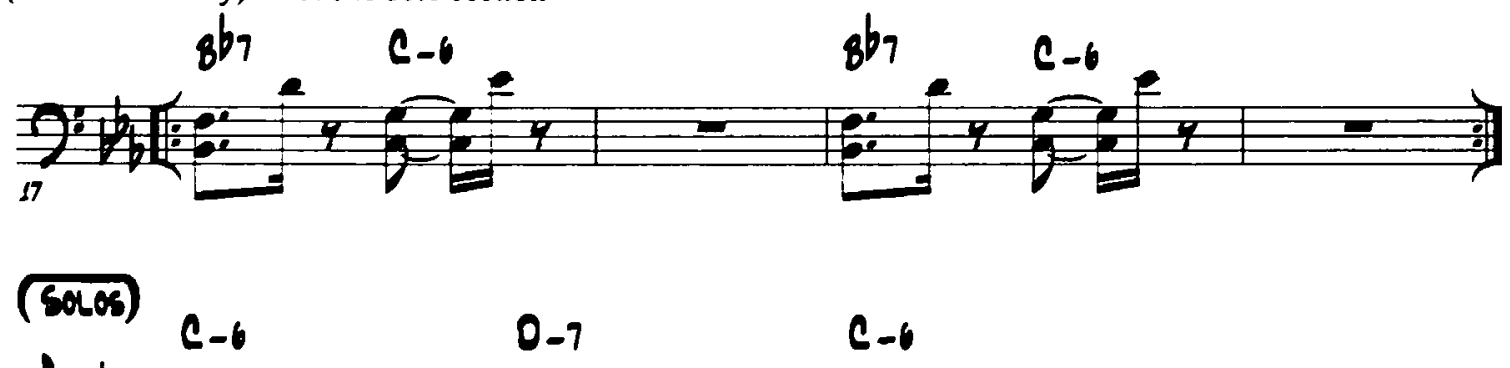

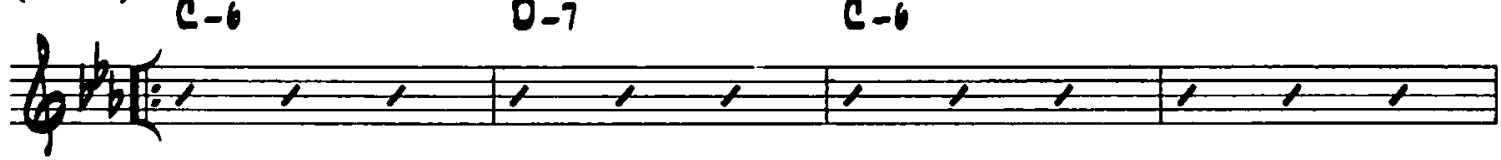
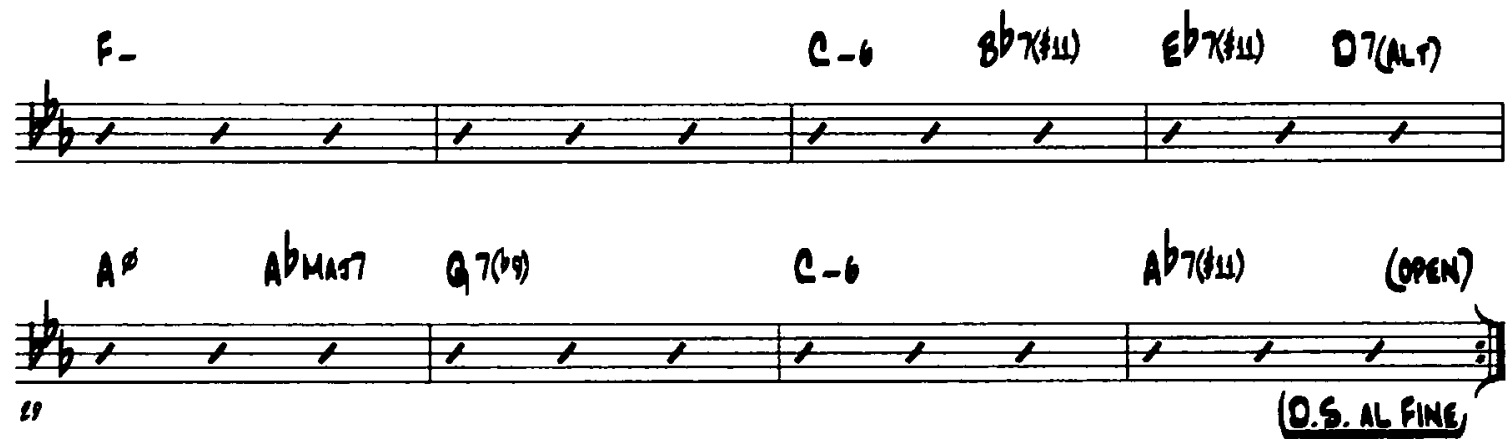
EL IMMIGeanTE

Agustrin CoNT

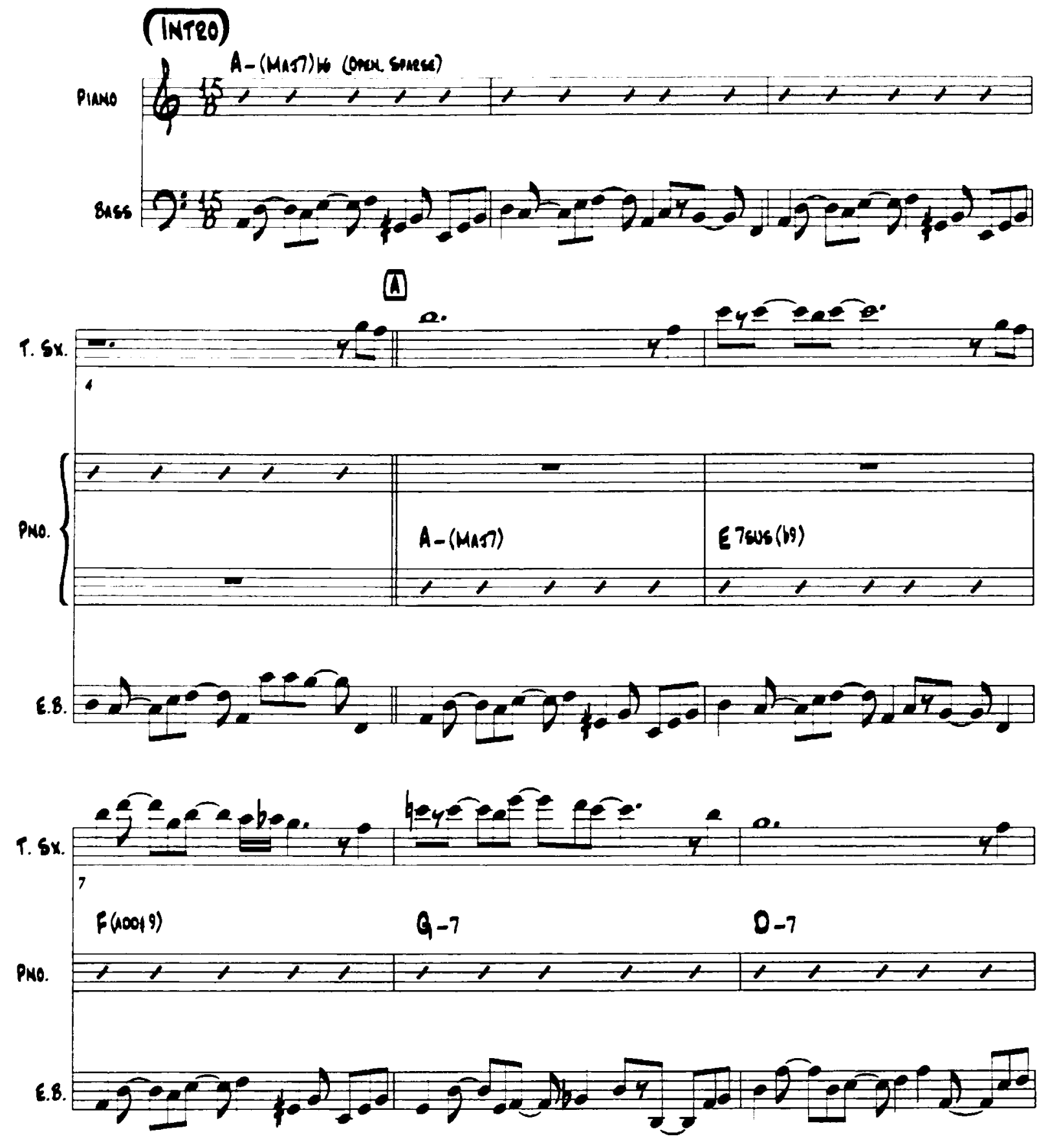

39 


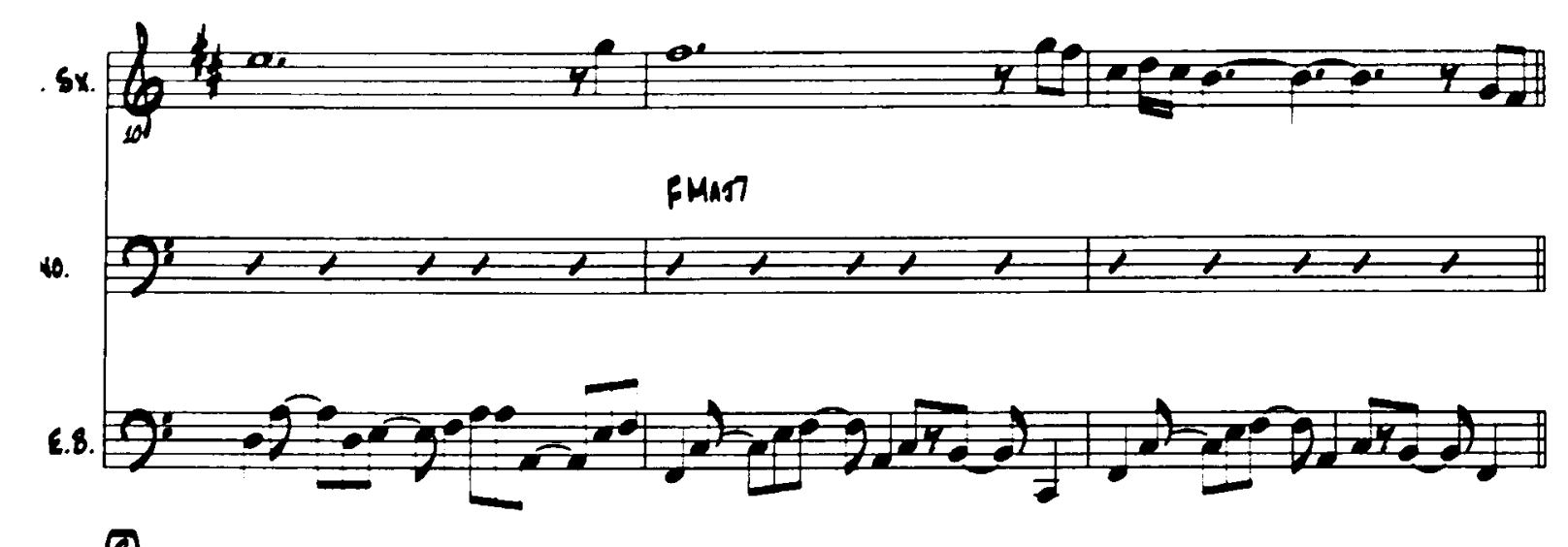

(B)
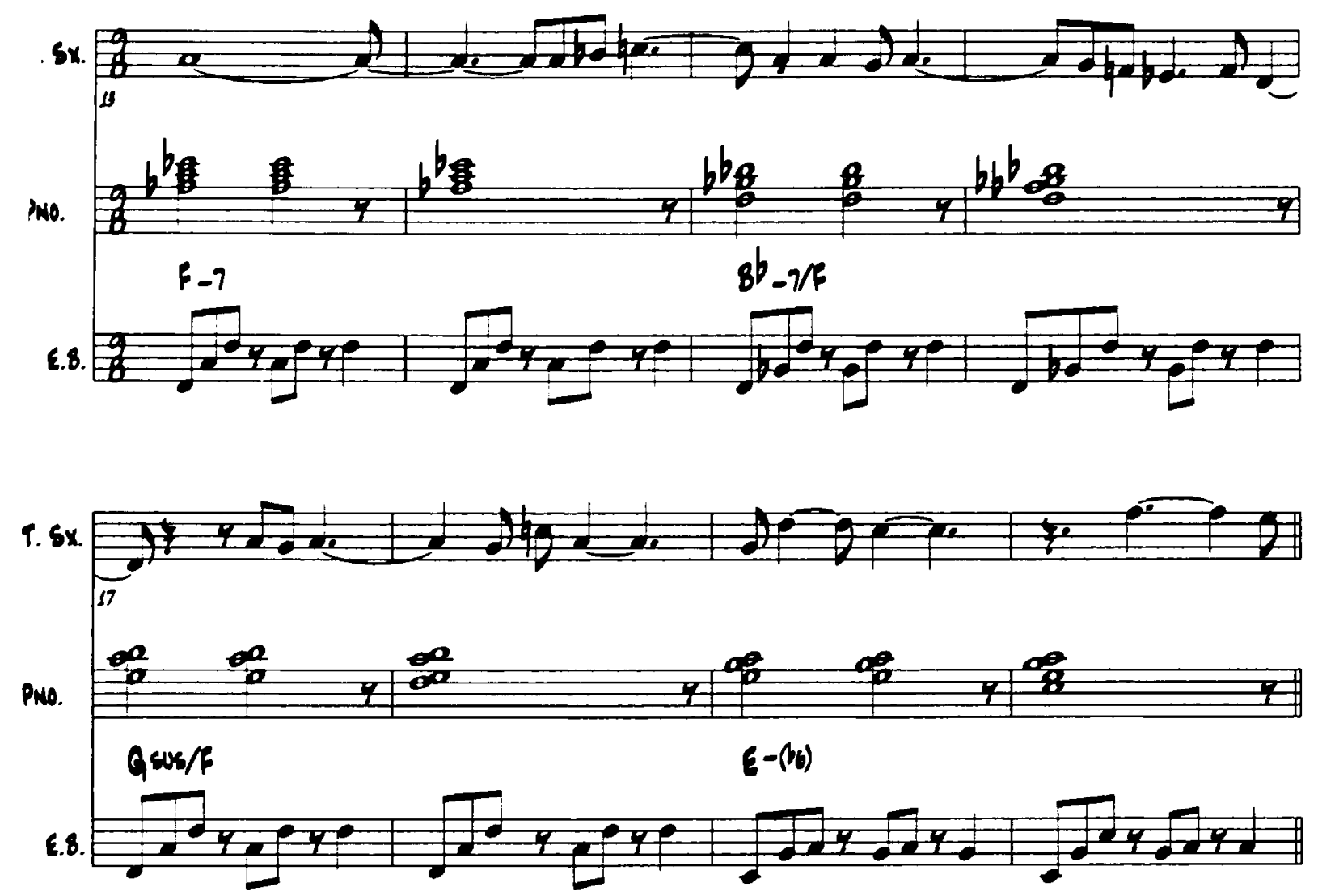
1.5x. $64+2$

PNo.

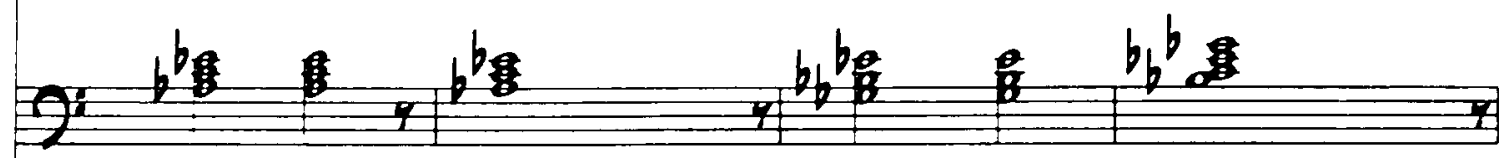

6.8.

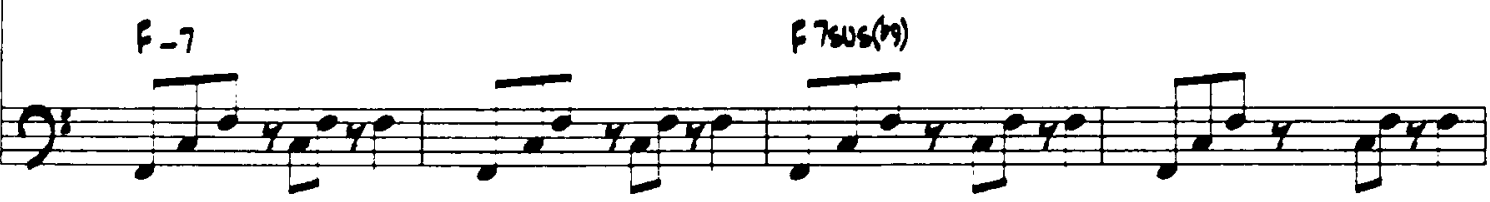

9.5x.

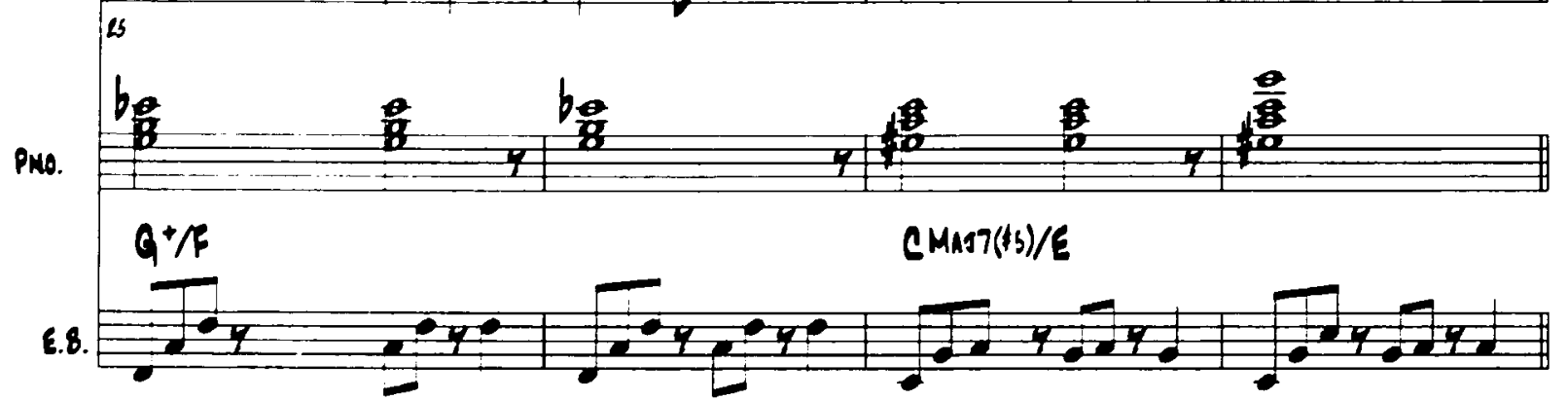

(A)

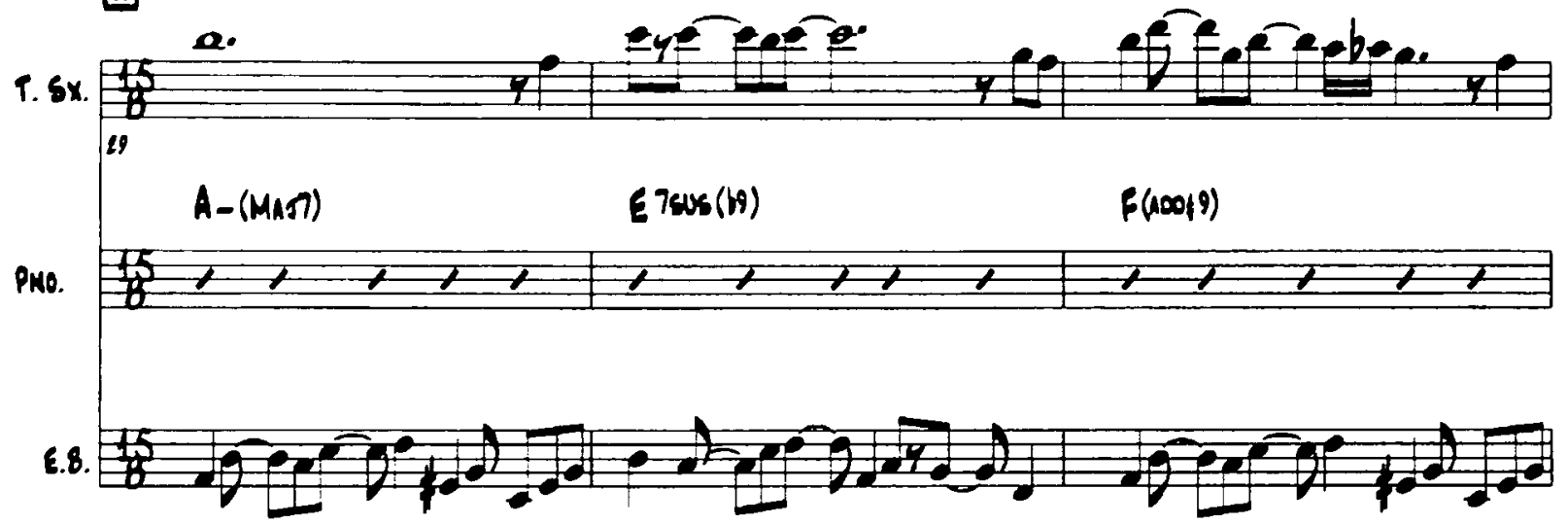


EL Lougewigre
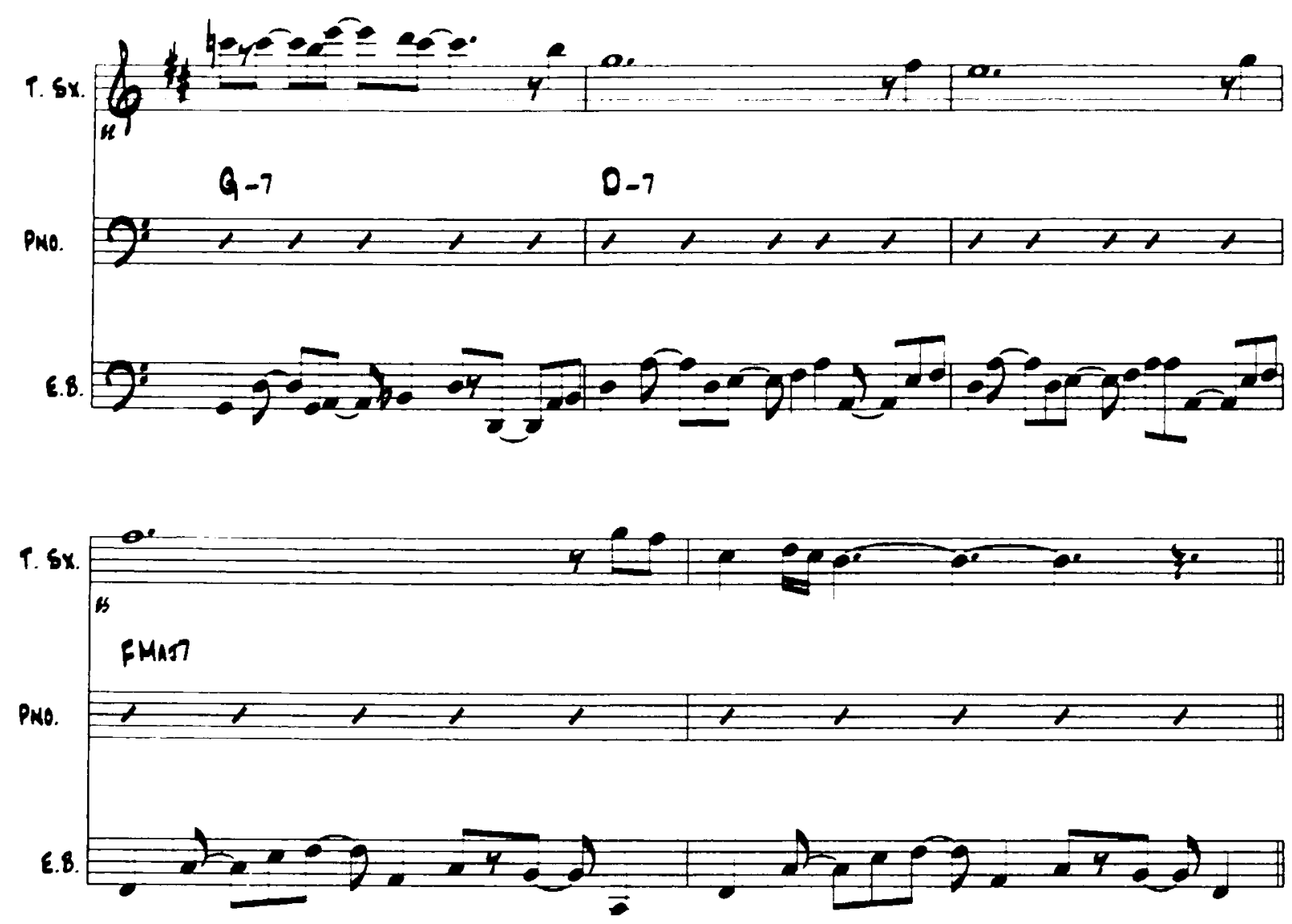

(C)

6.8.

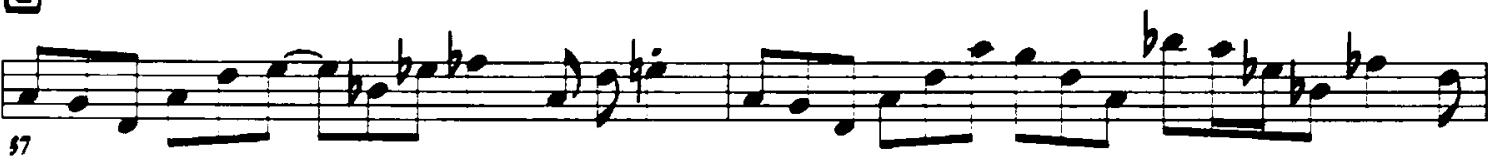

PNo. 
EL MMIGenkte
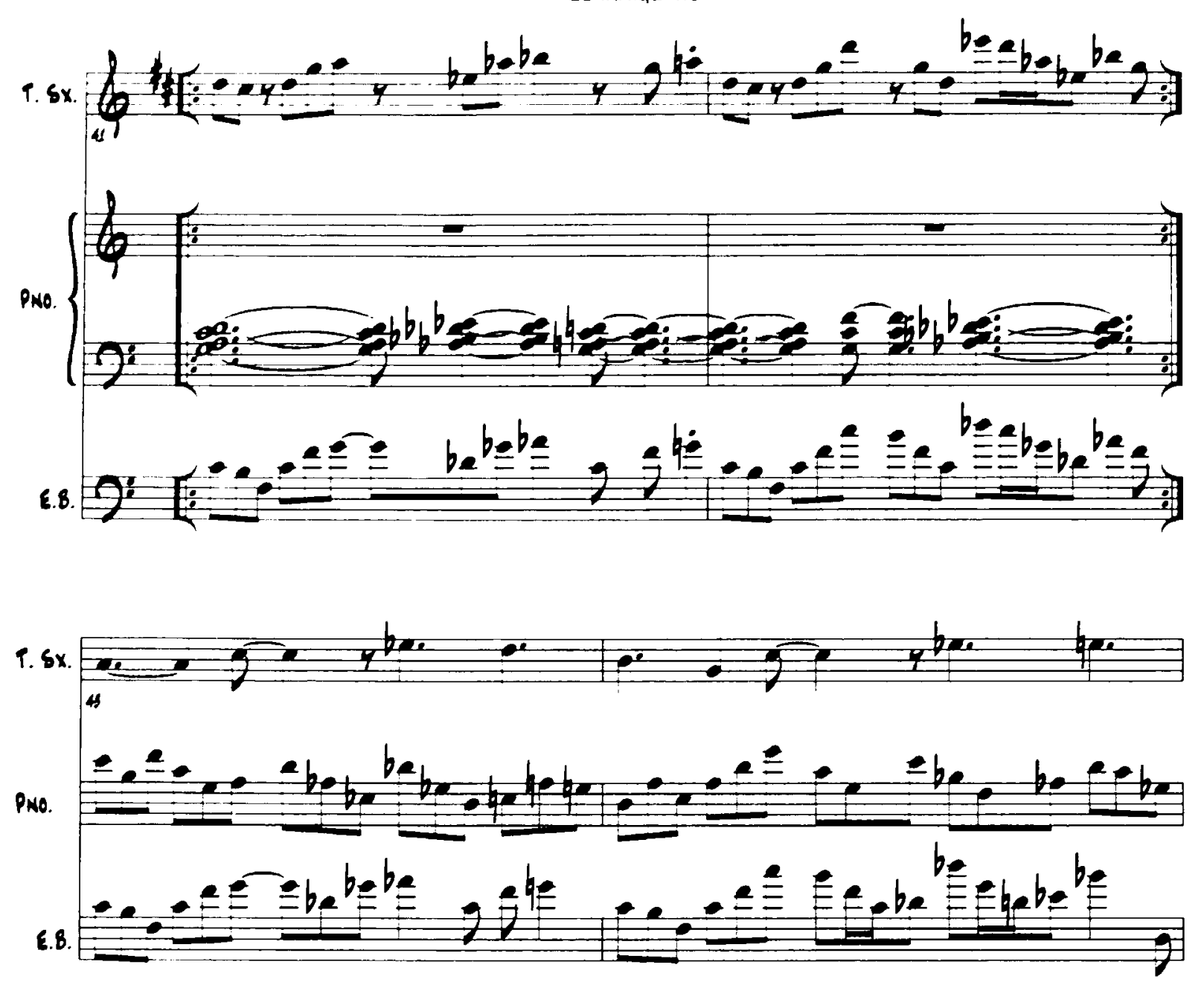

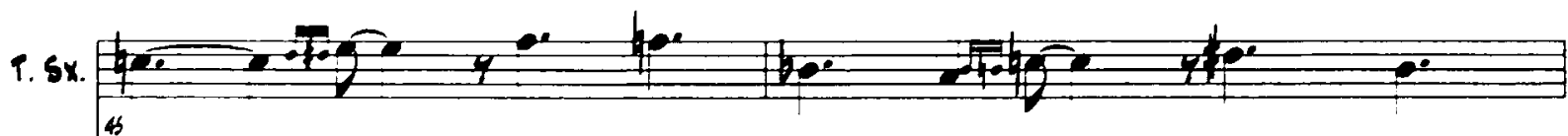

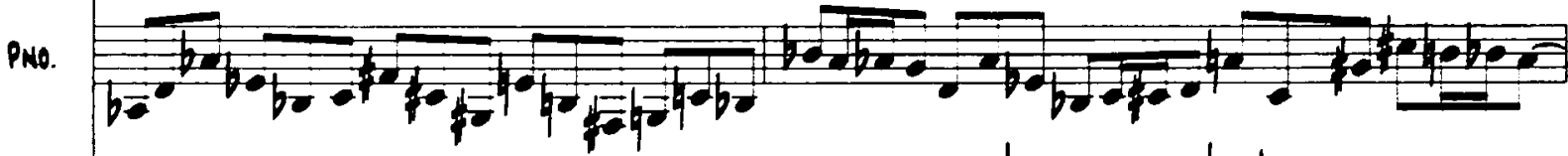

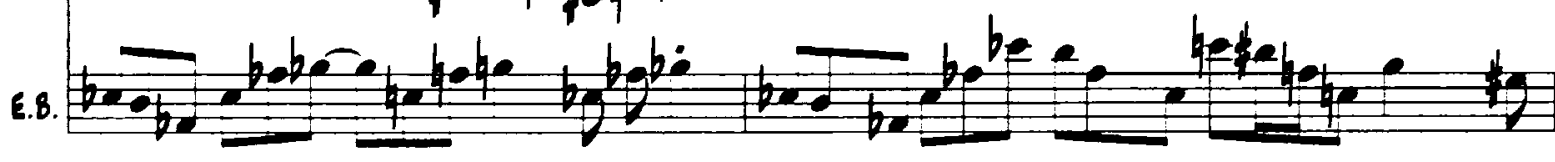



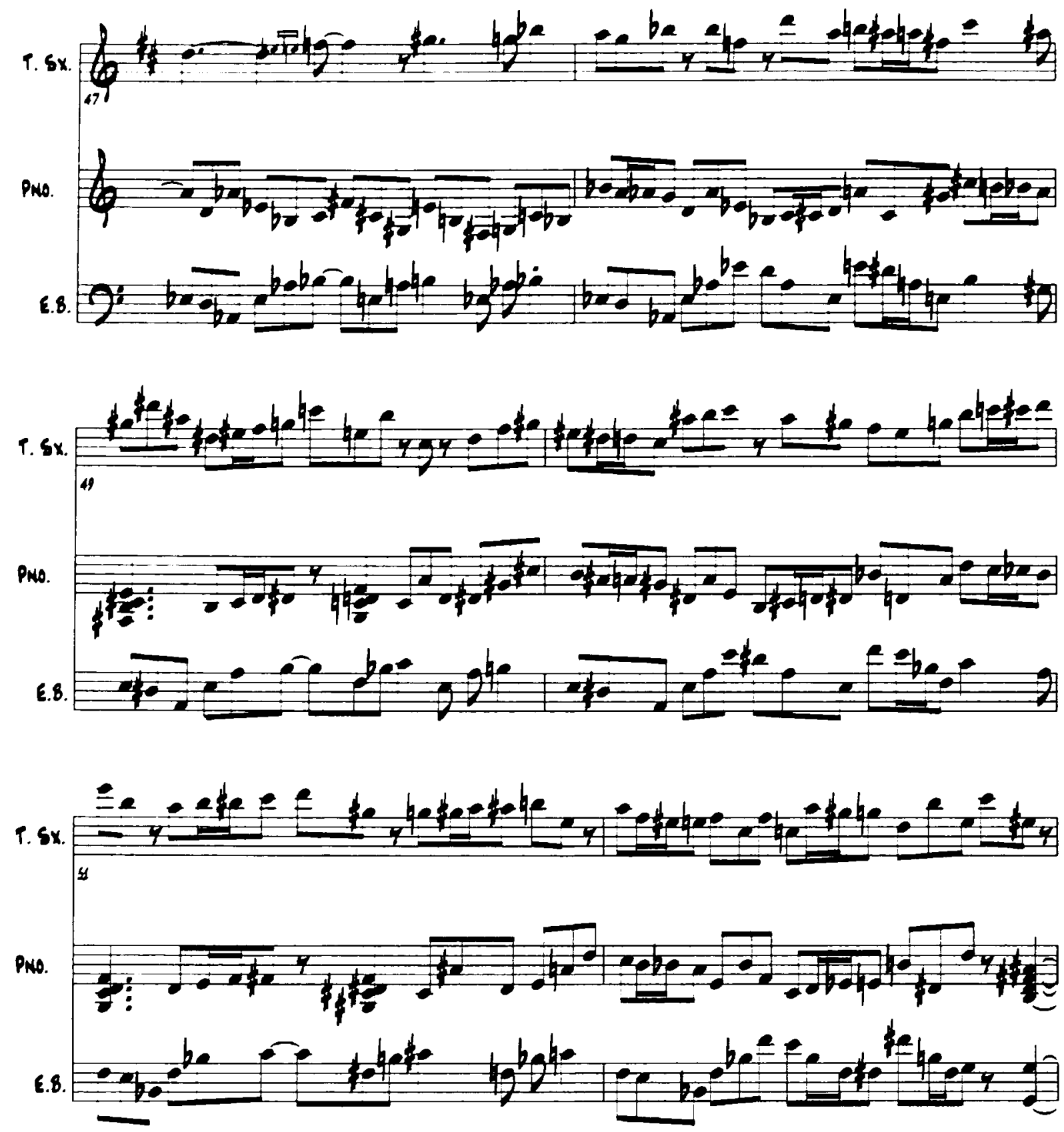
EL MAMLENTE

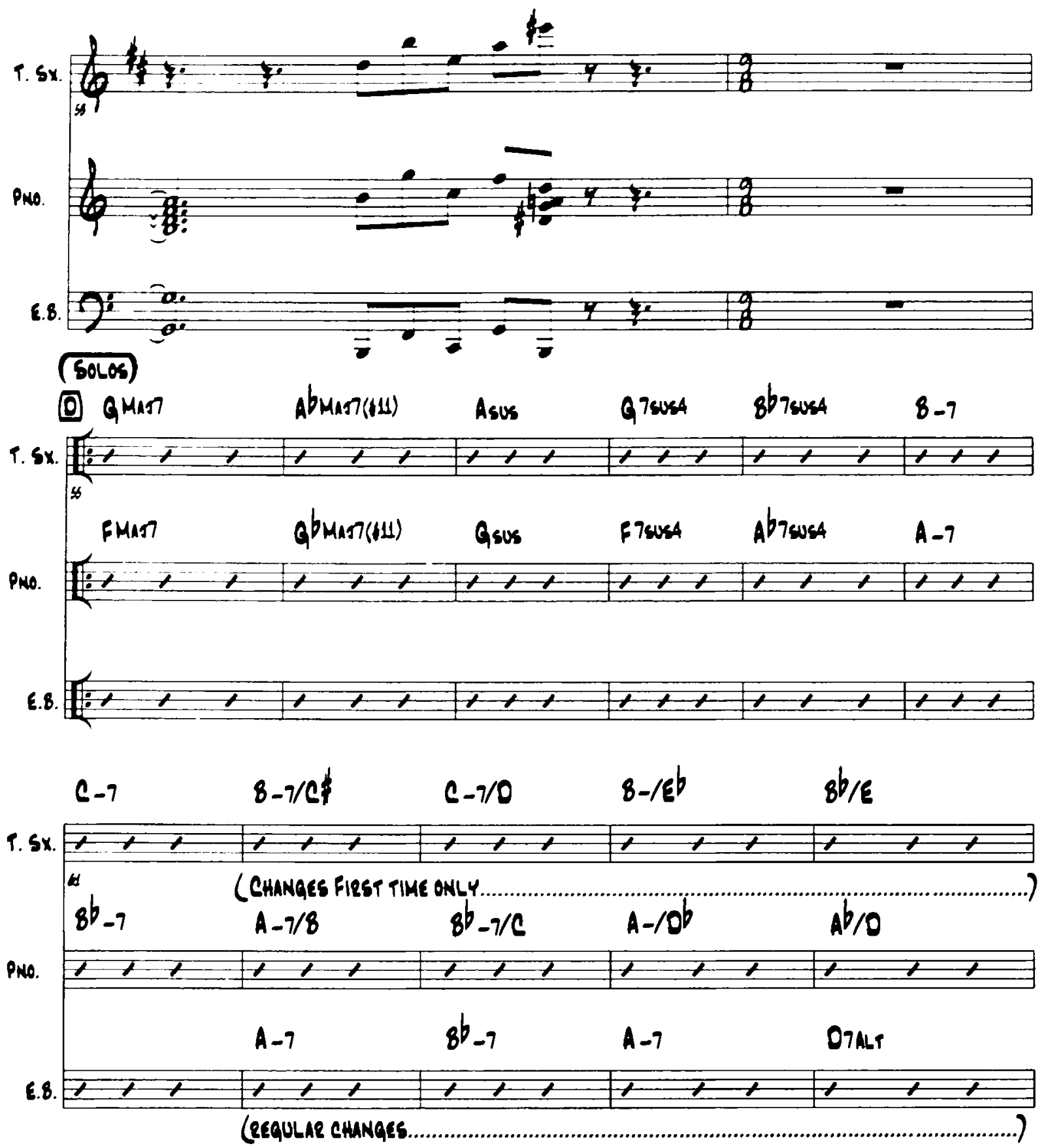

45 
EL Iragraente

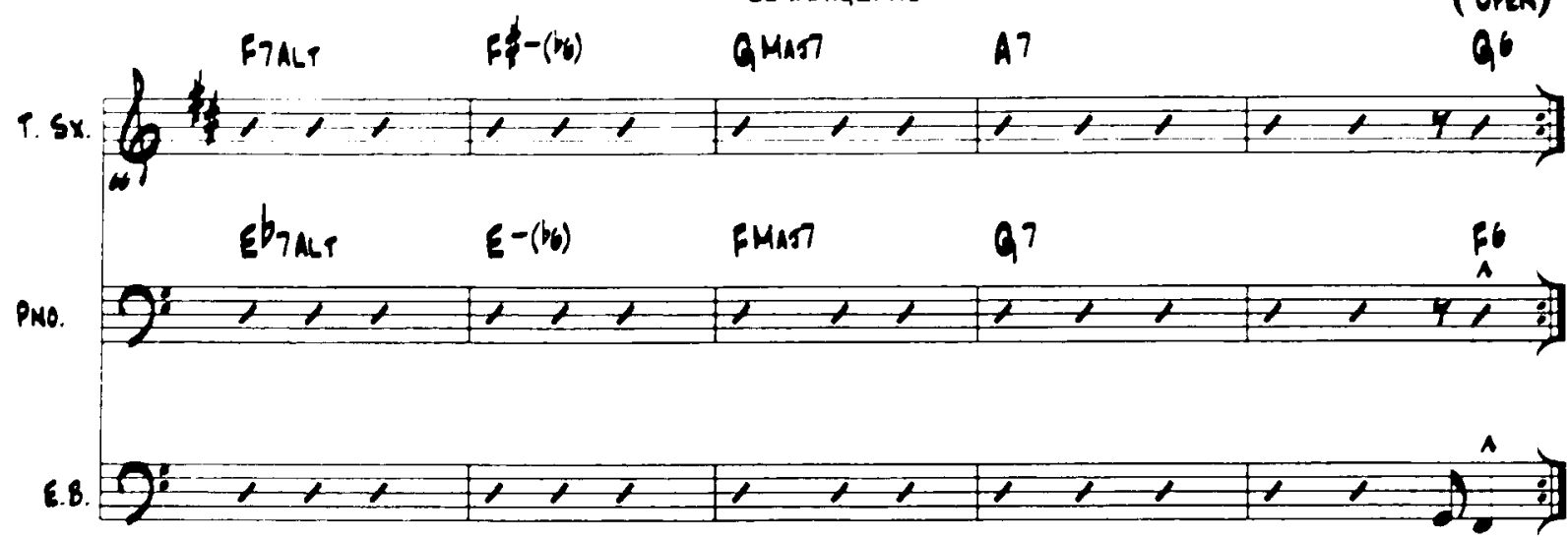

(B)
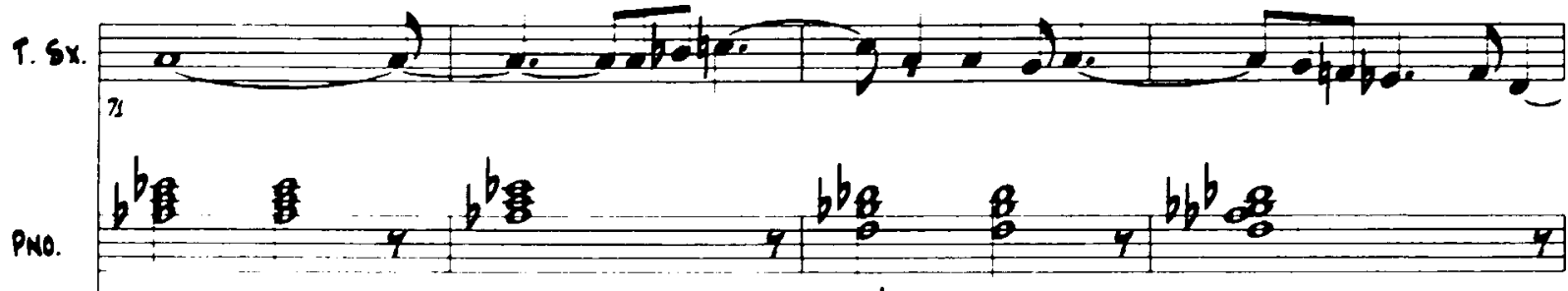
$\beta-7 \quad B^{b}-7 / 6$

6.8.

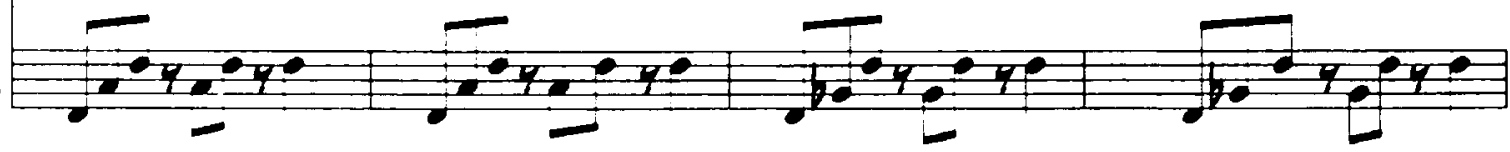

9.5x.

PNo.

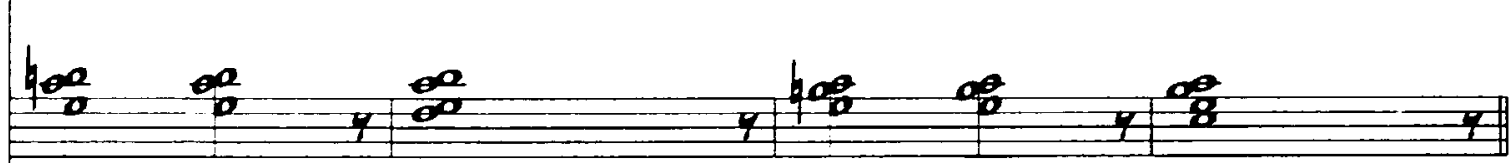

6.8.

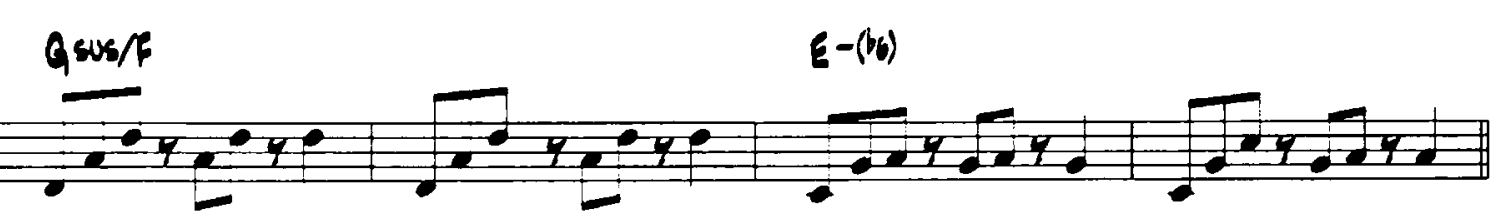



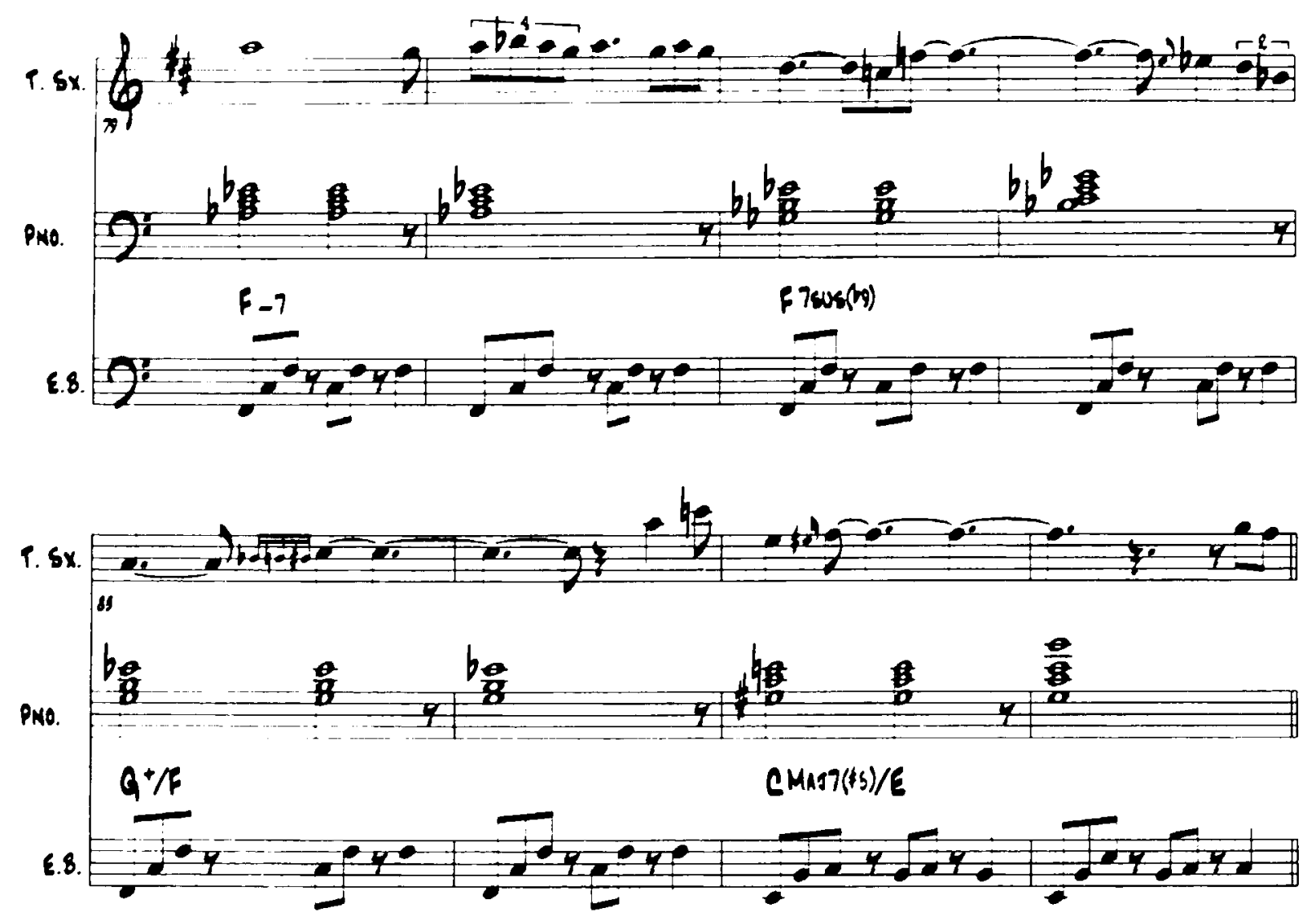

\section{(A)}

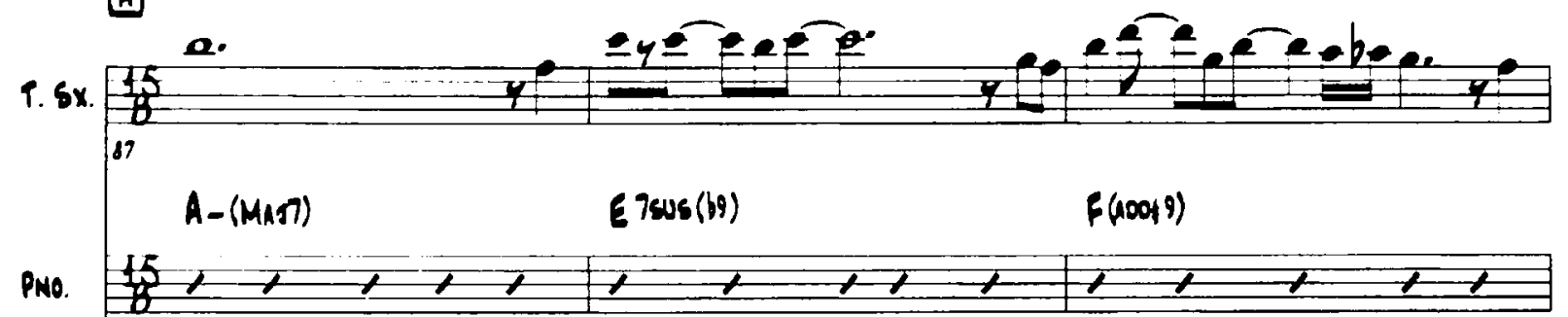

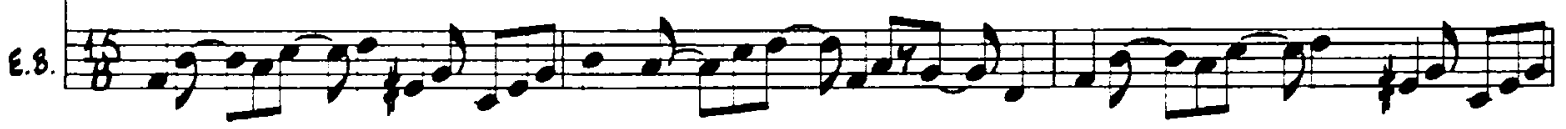



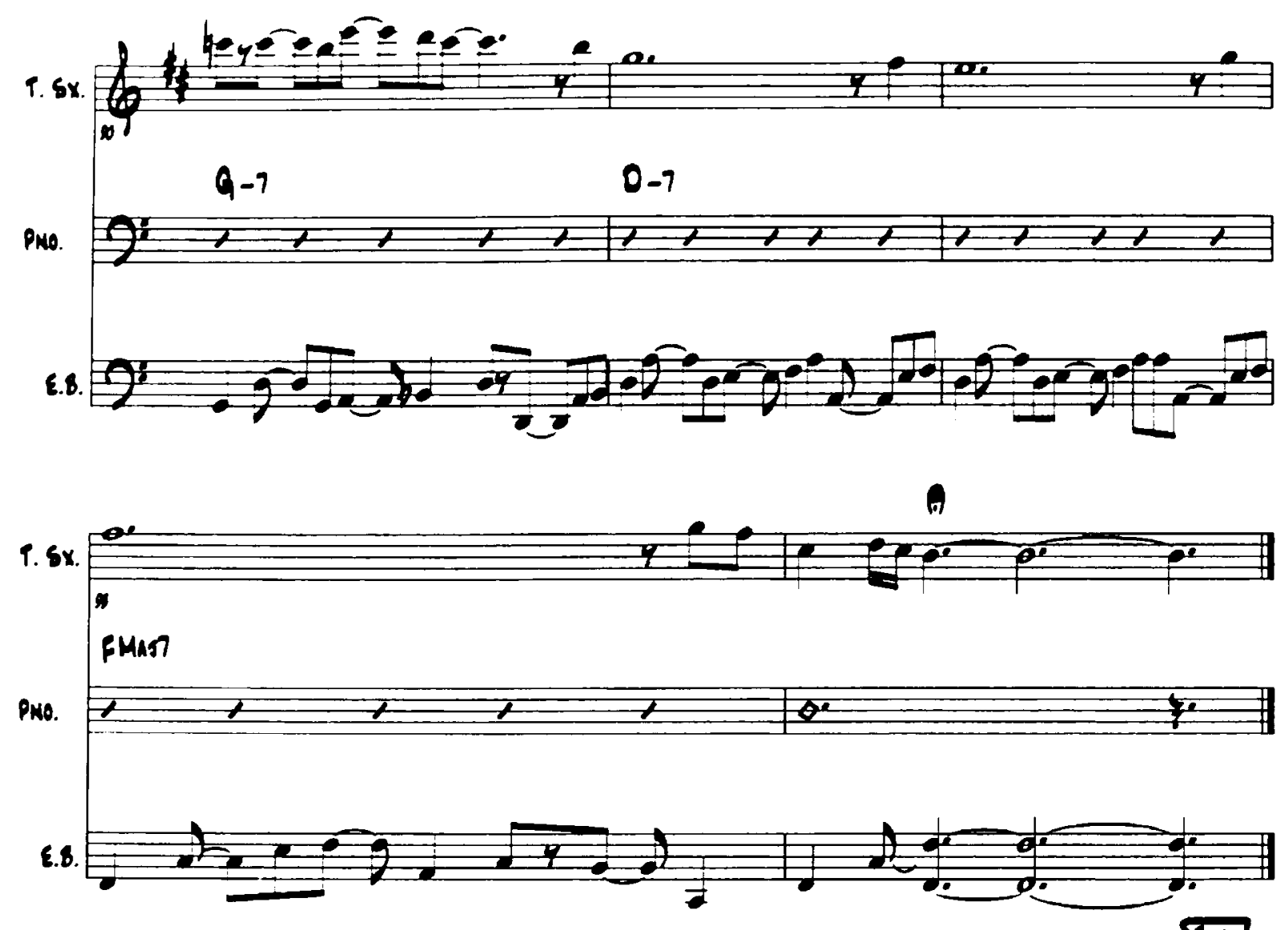

EIME 
(NTPO)

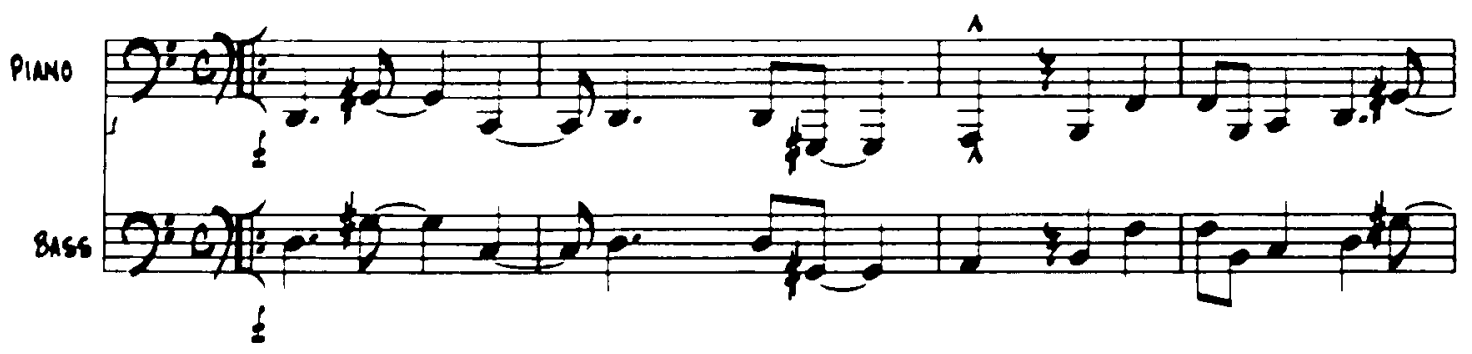

PNO.

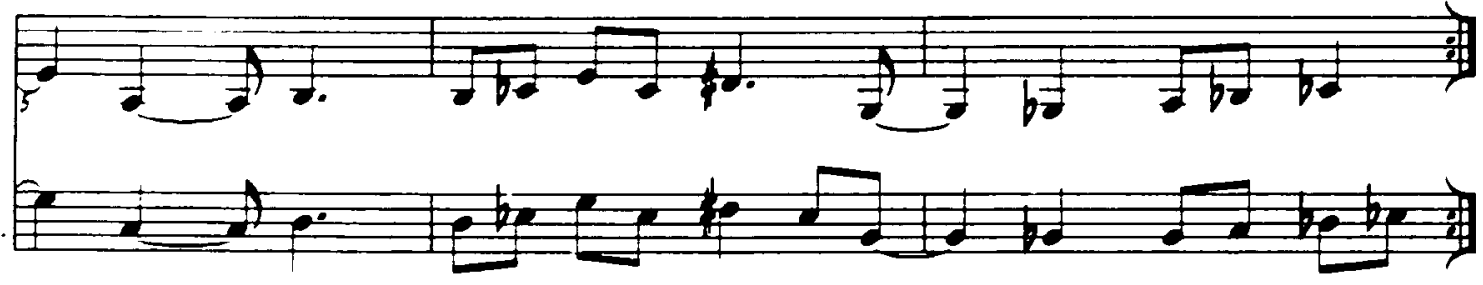

(A)

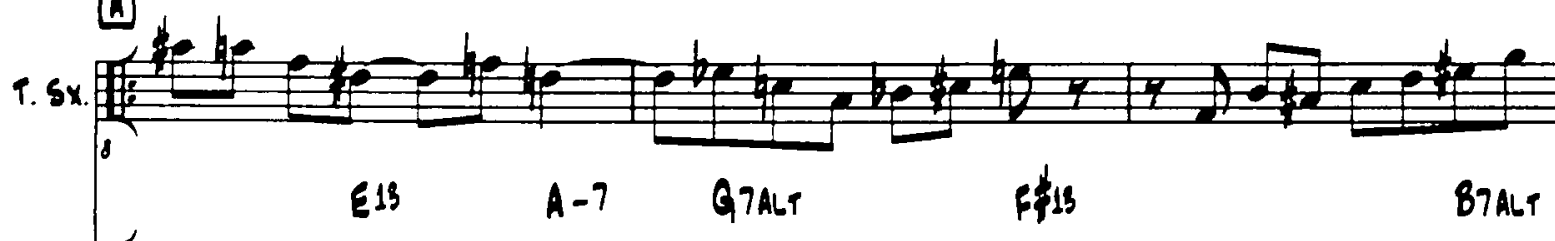

PNo.

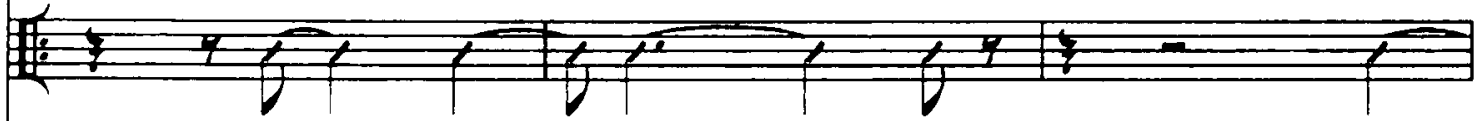

6.8.

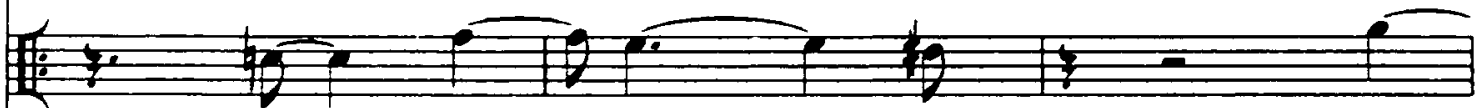

D. 5

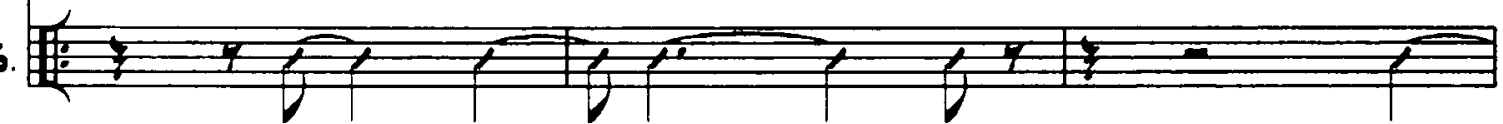



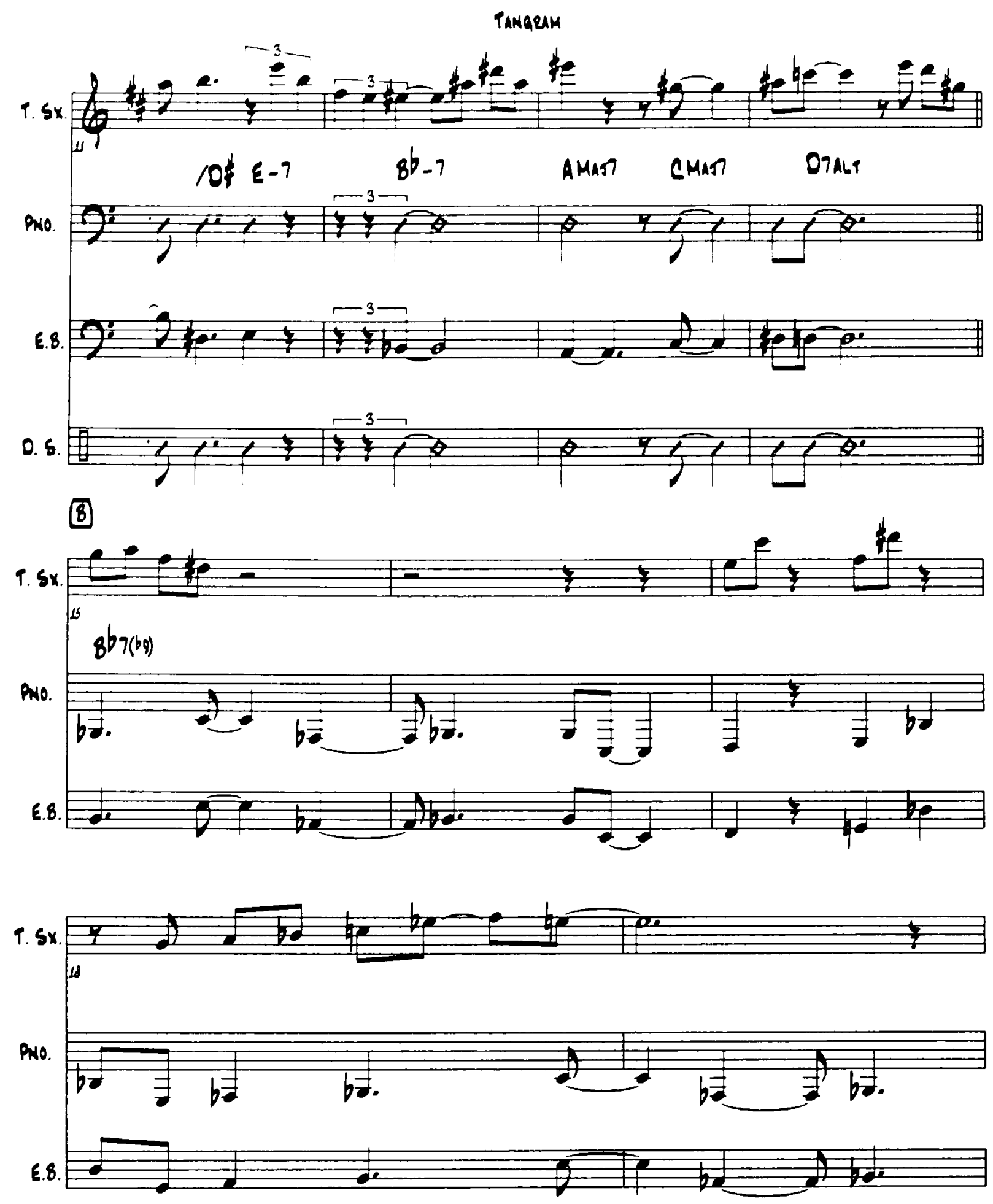


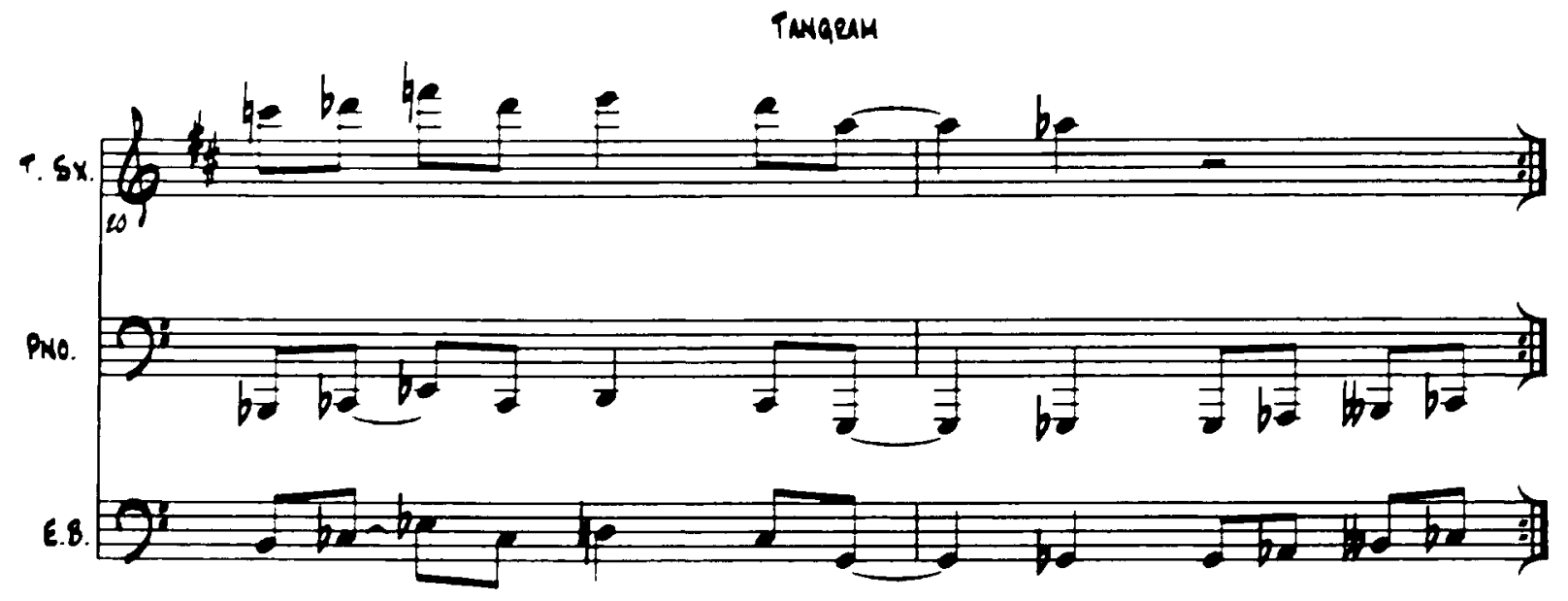

$d=d$ (shachecen bert)
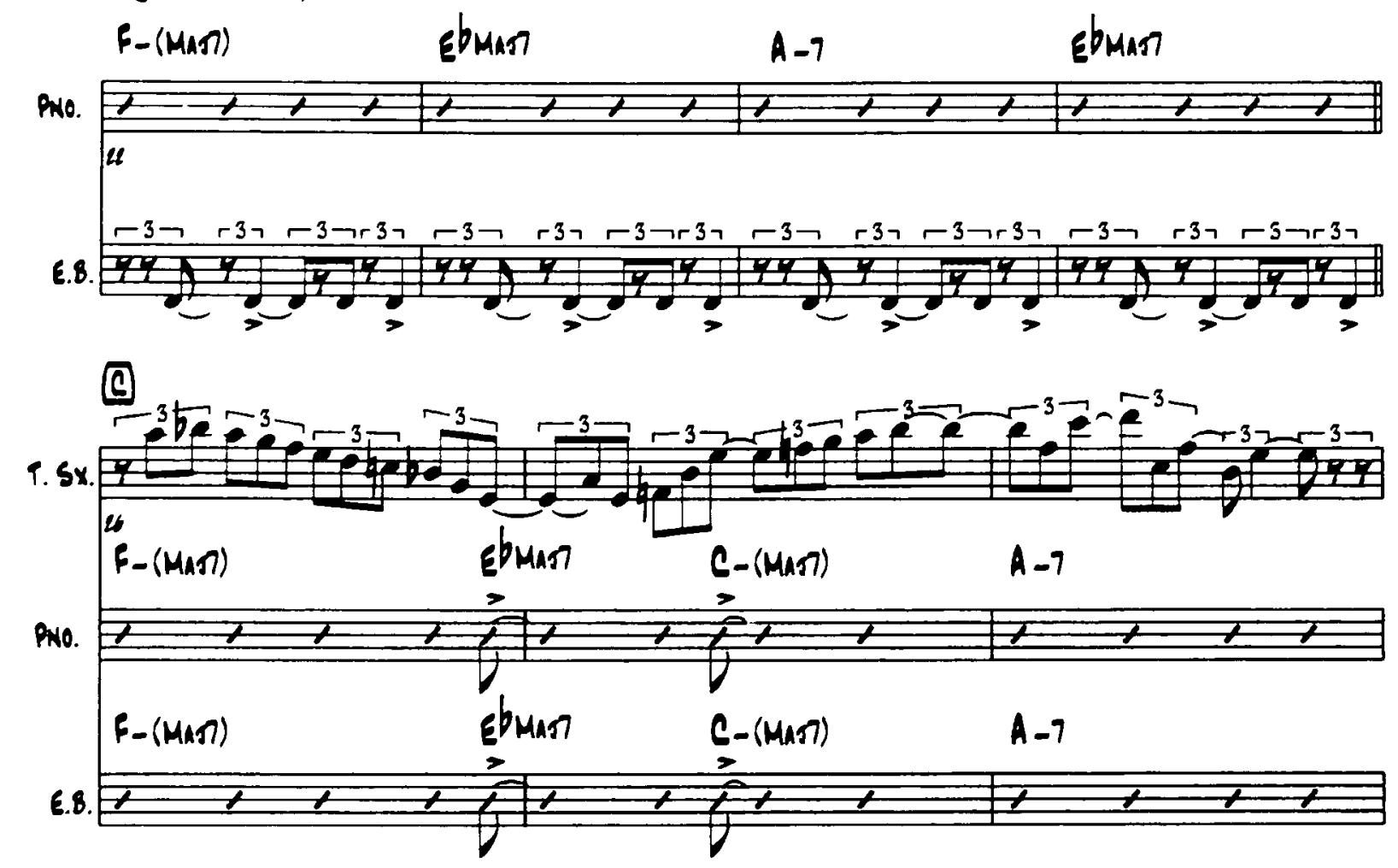

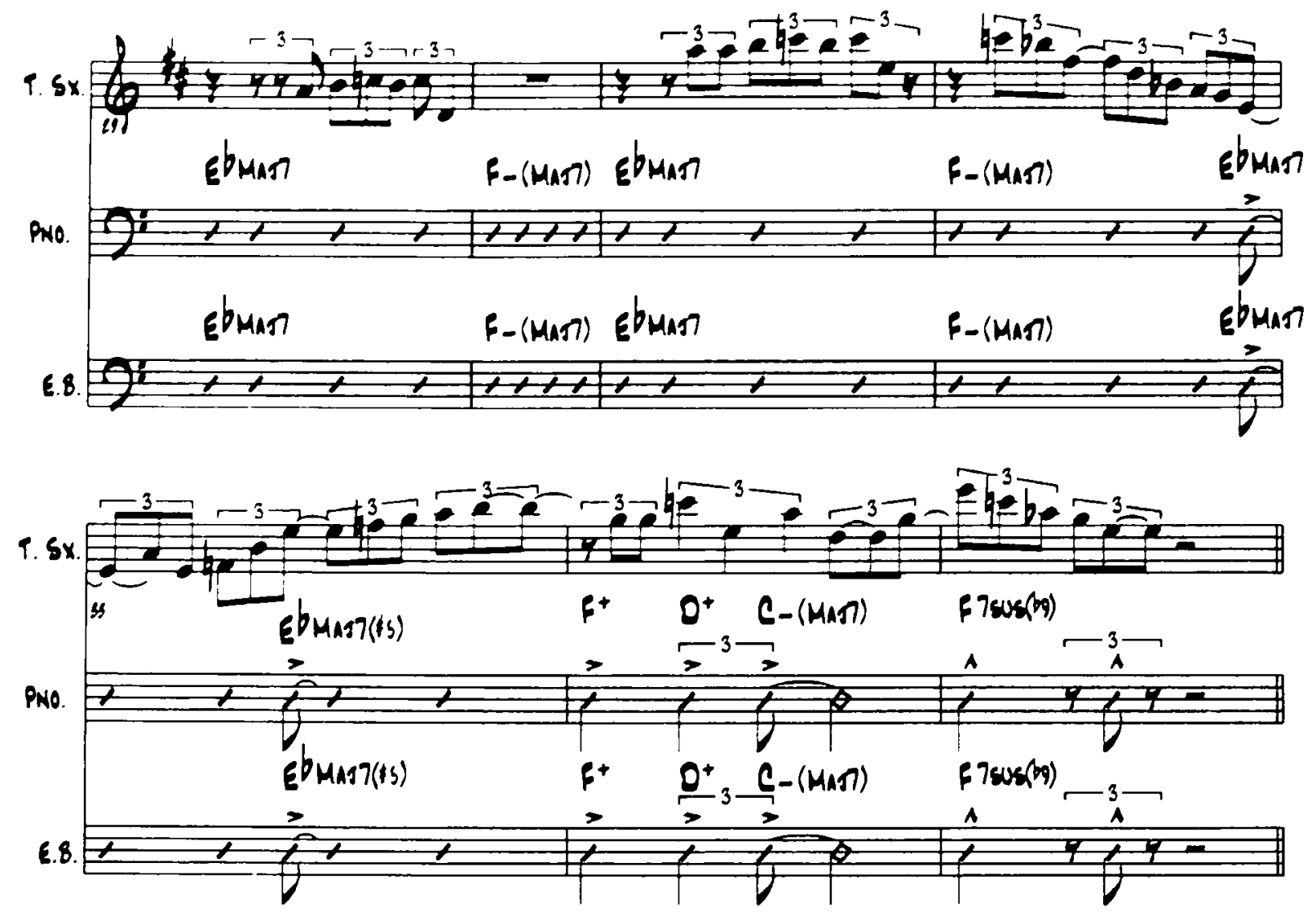

\section{(A) $d=d$}

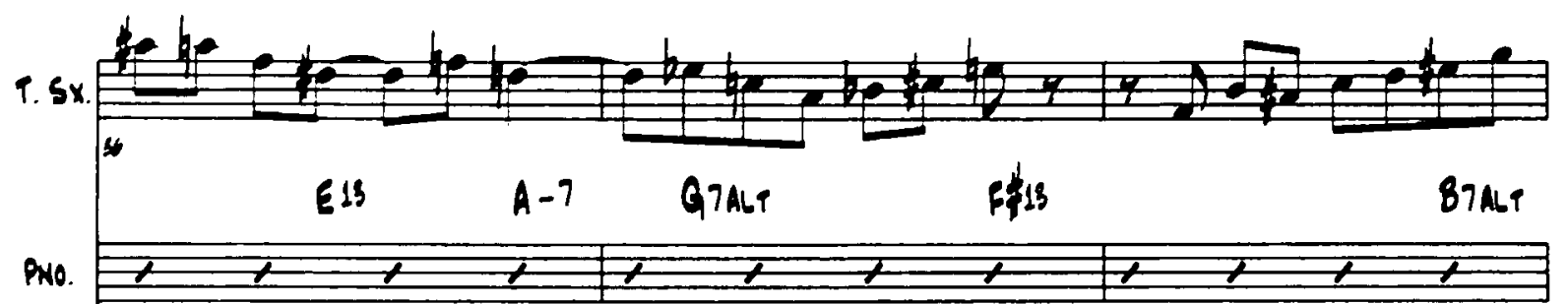

6.8.

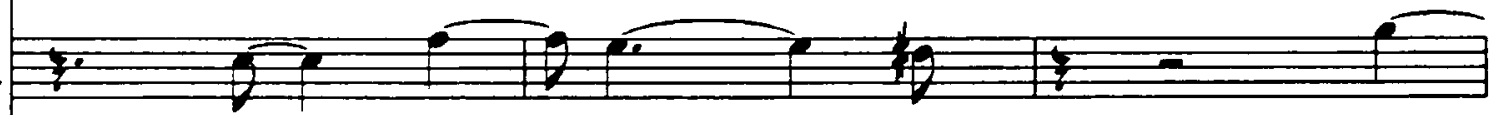

0.5.

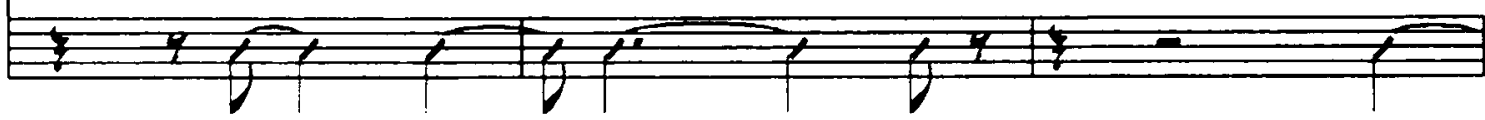



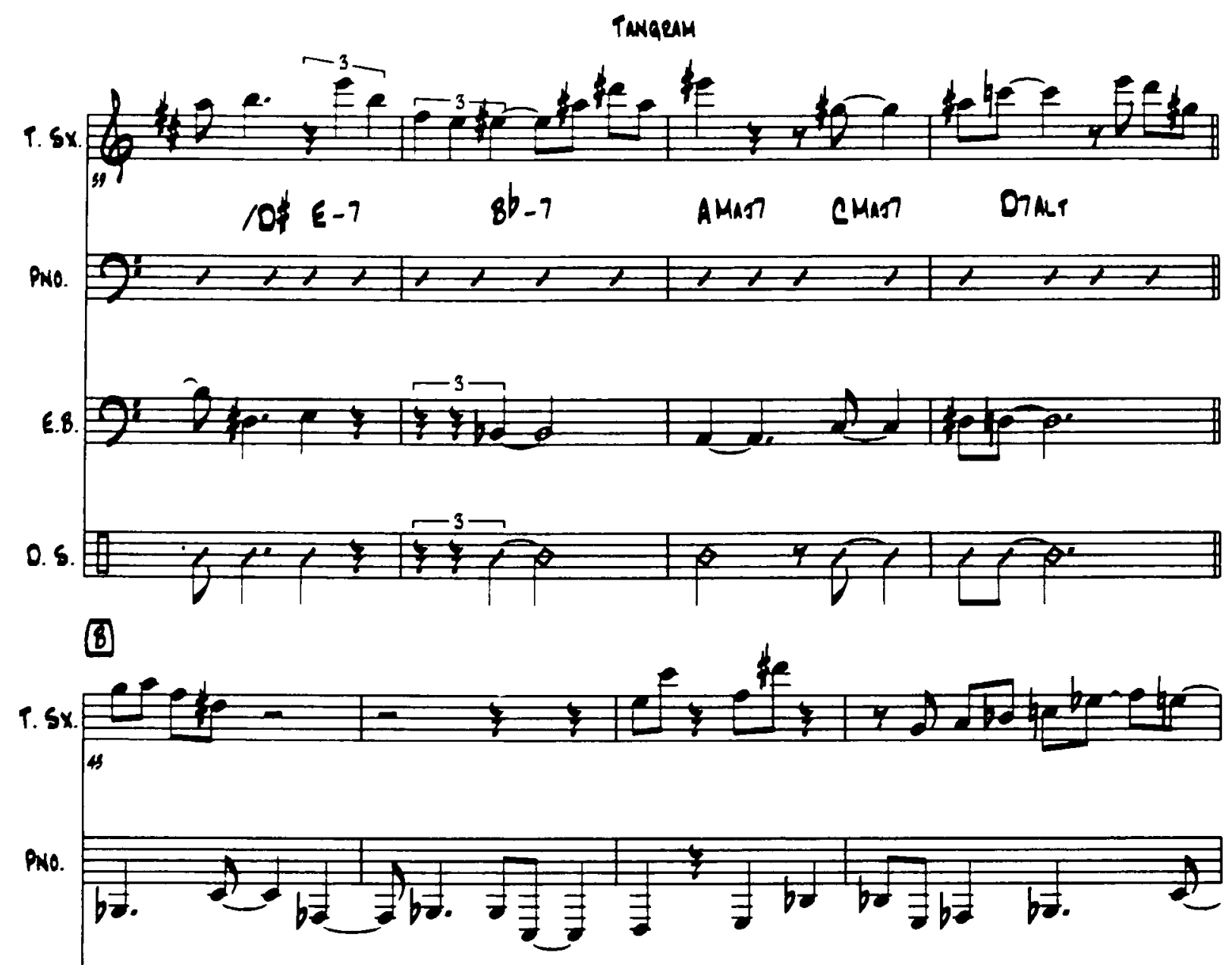

6.8.
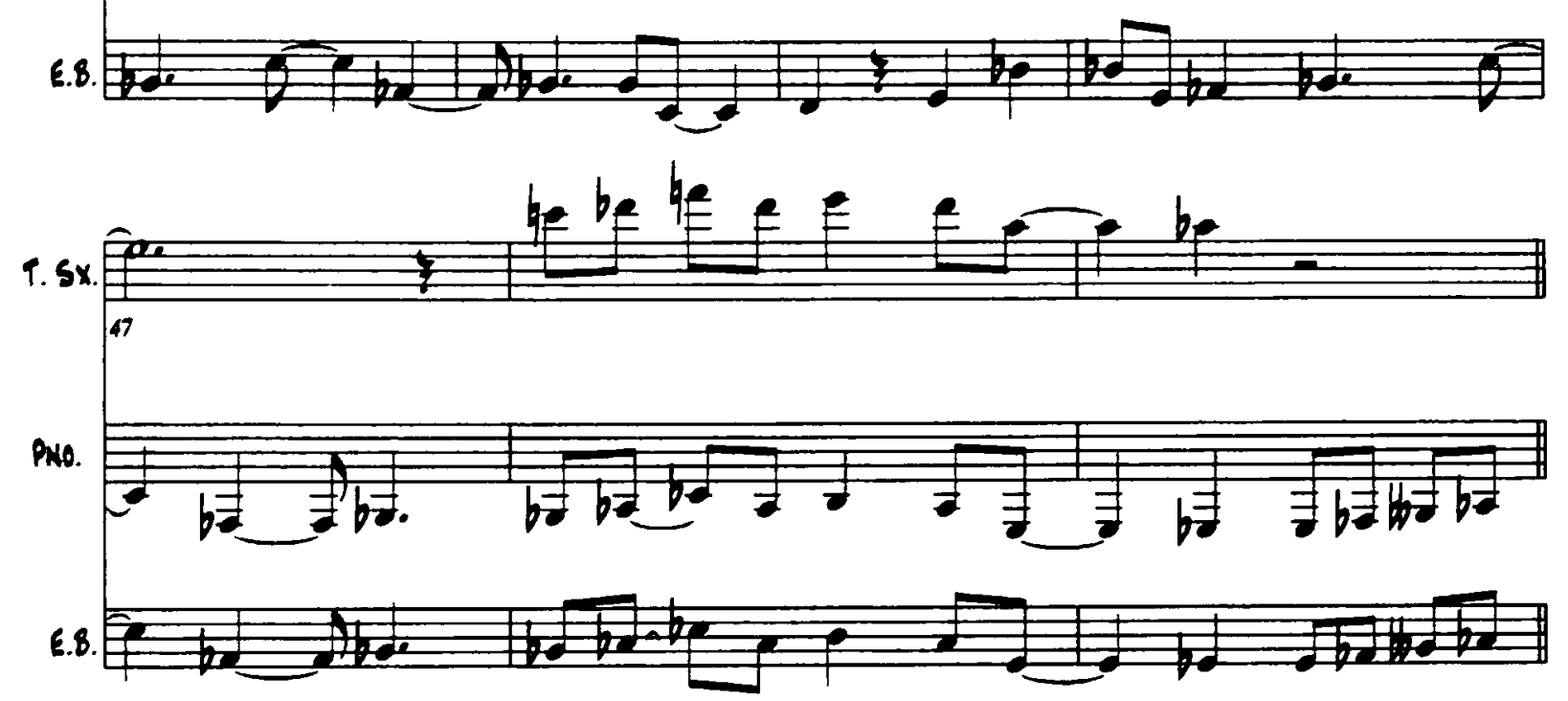

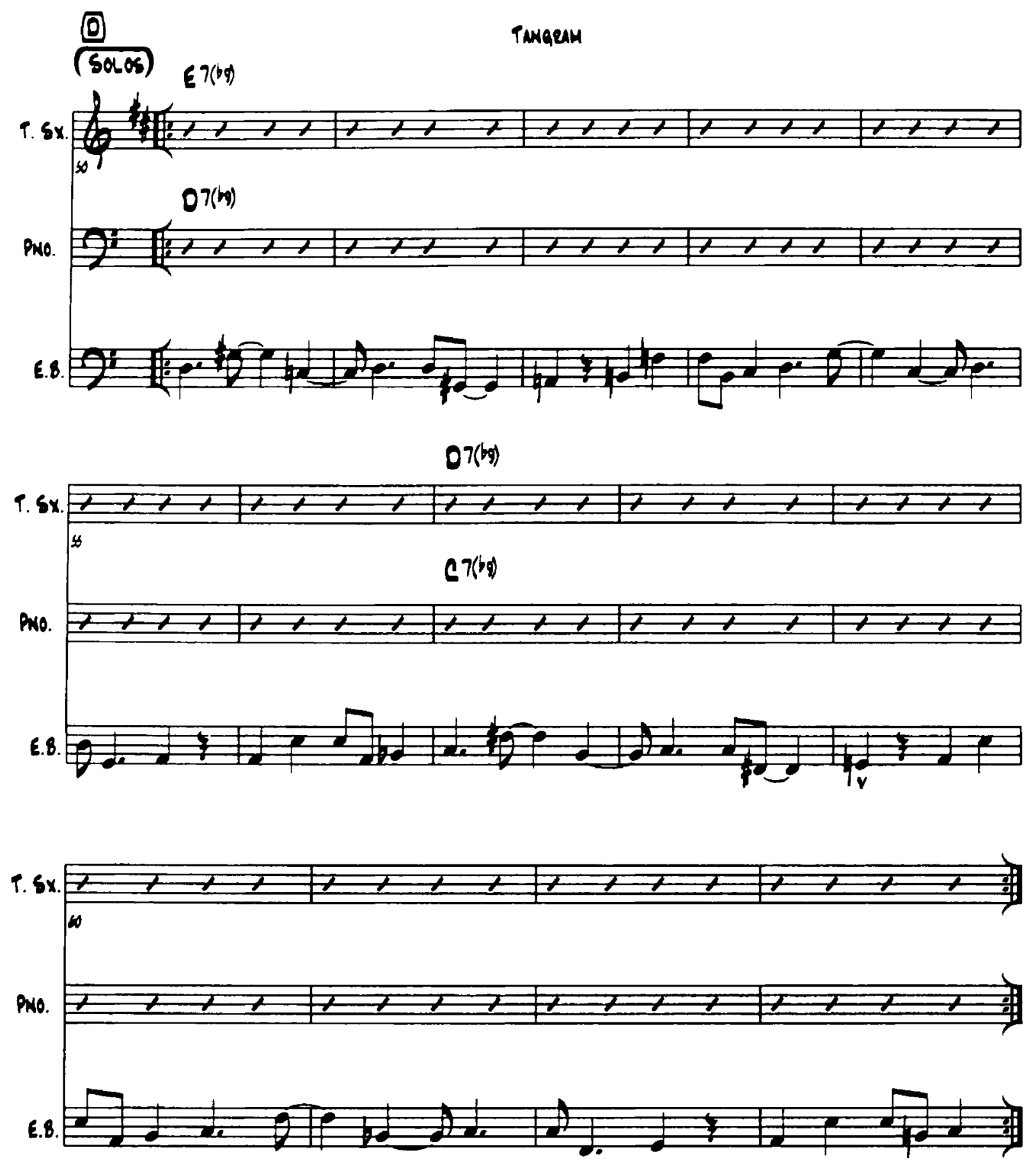

54 
TAMEQAM

ebmas?

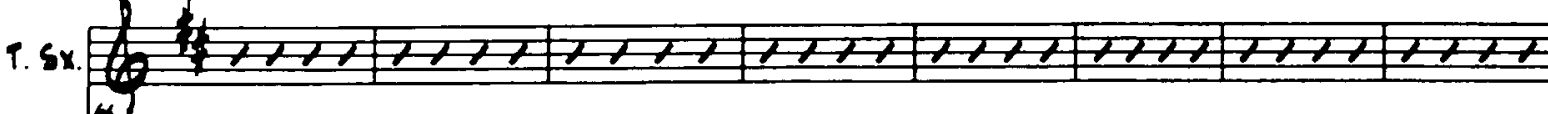

obuas

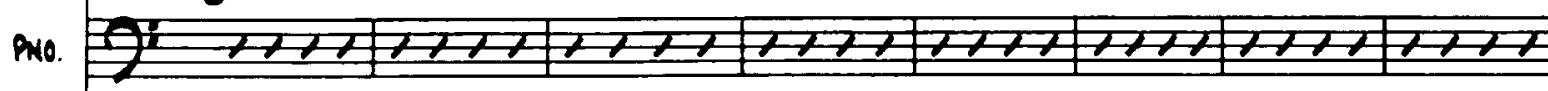

obmast
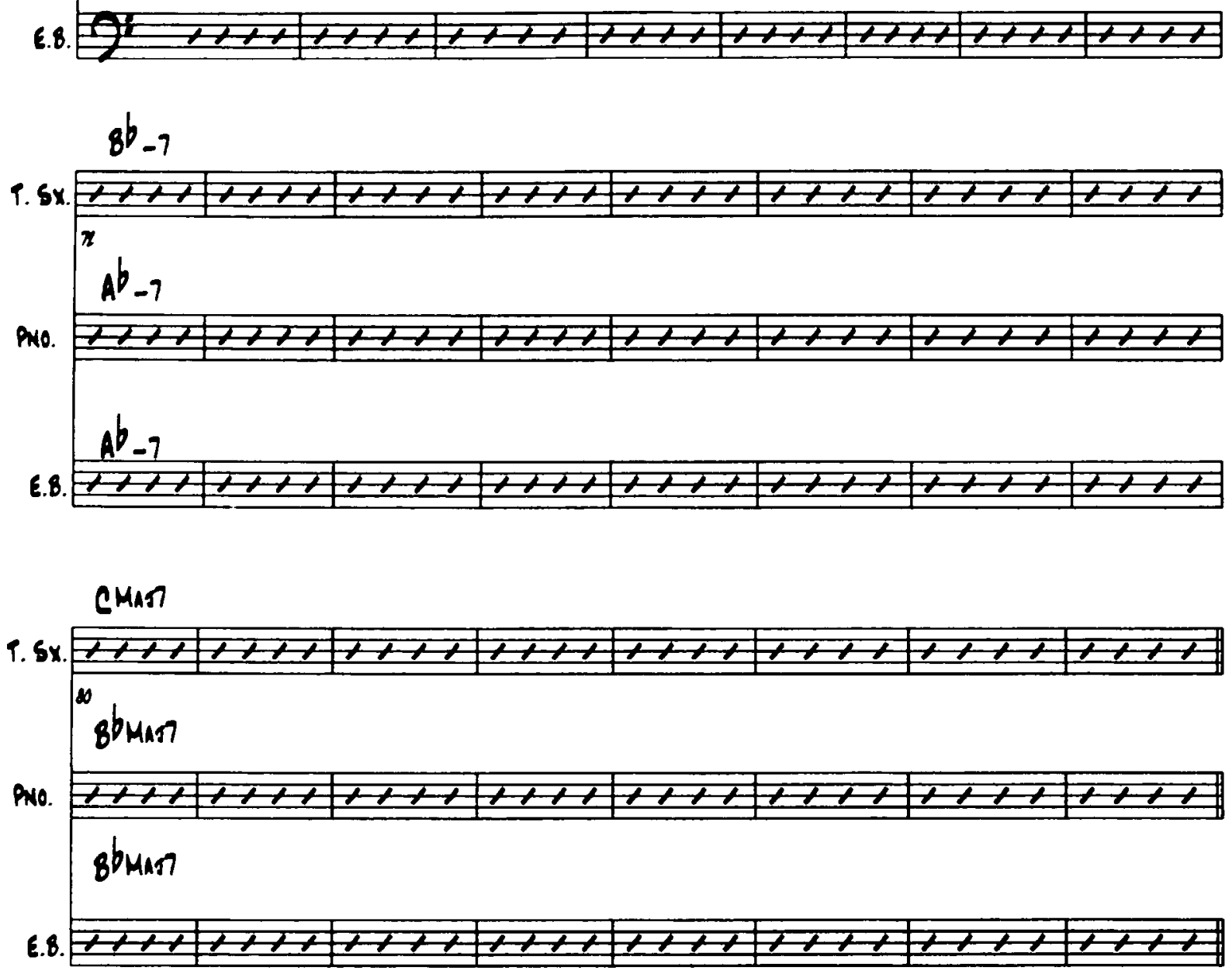

55 


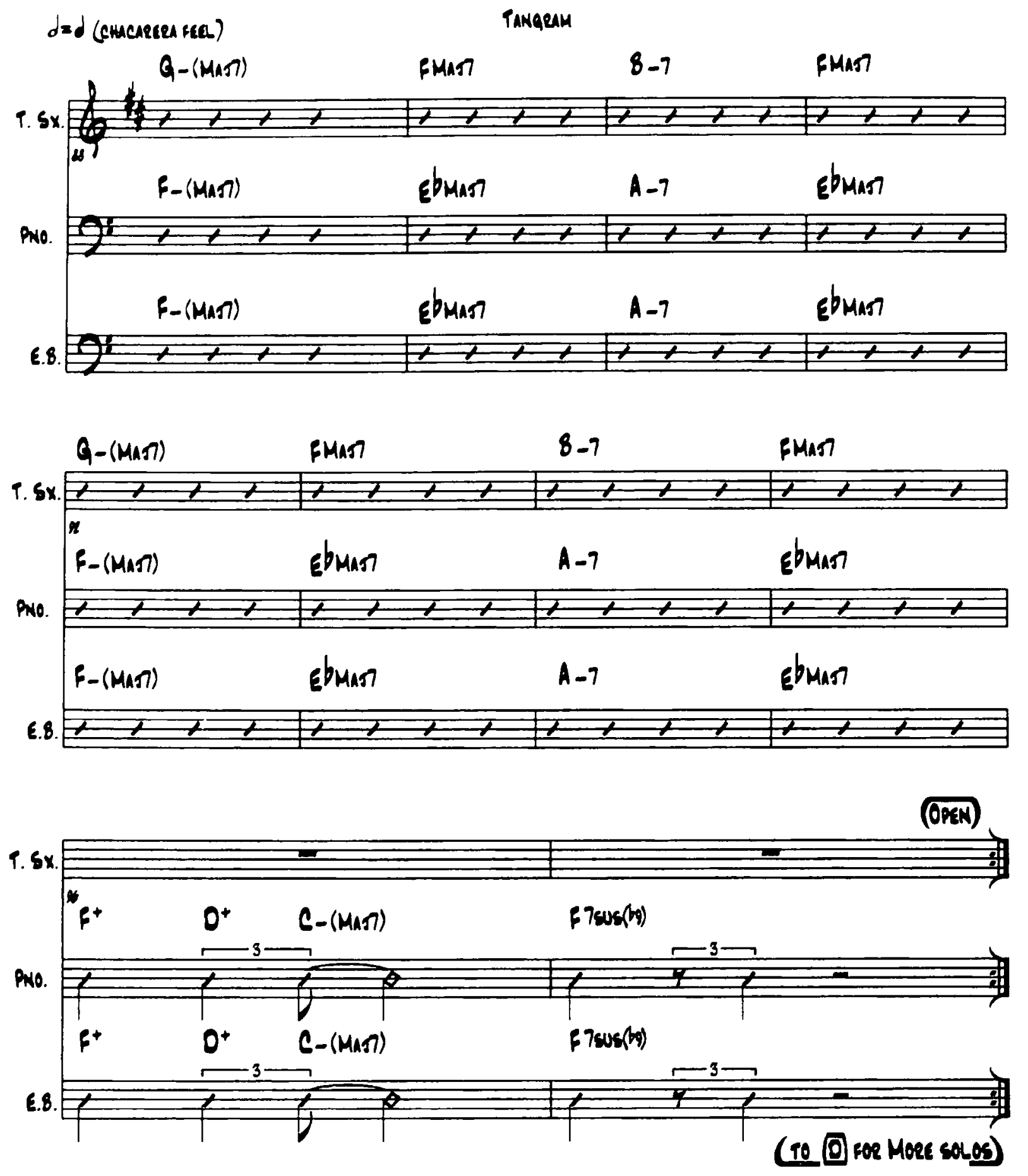

56 
(G) (OREN Deuns SO.0) dzd

Pangeum
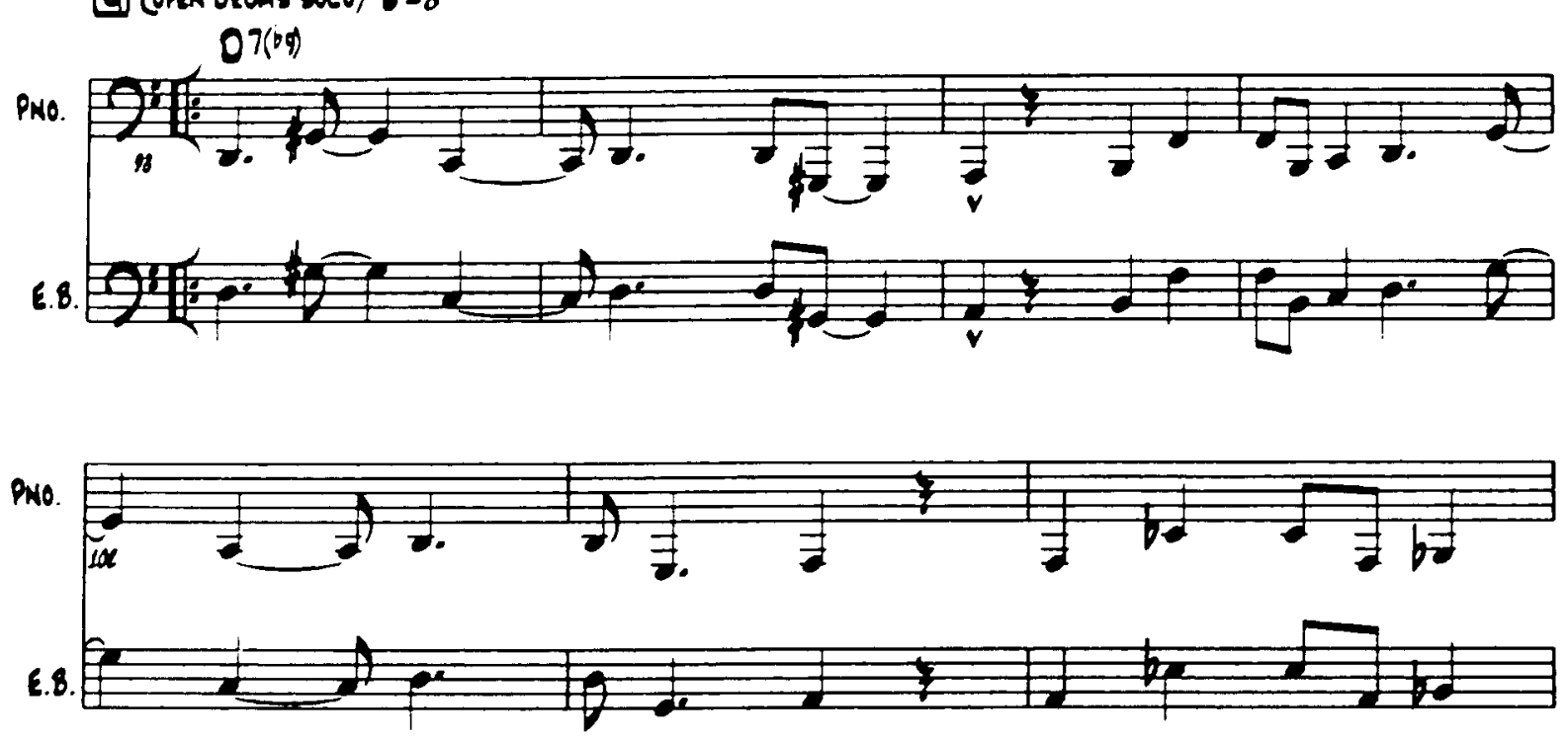

$C 7(b 9)$
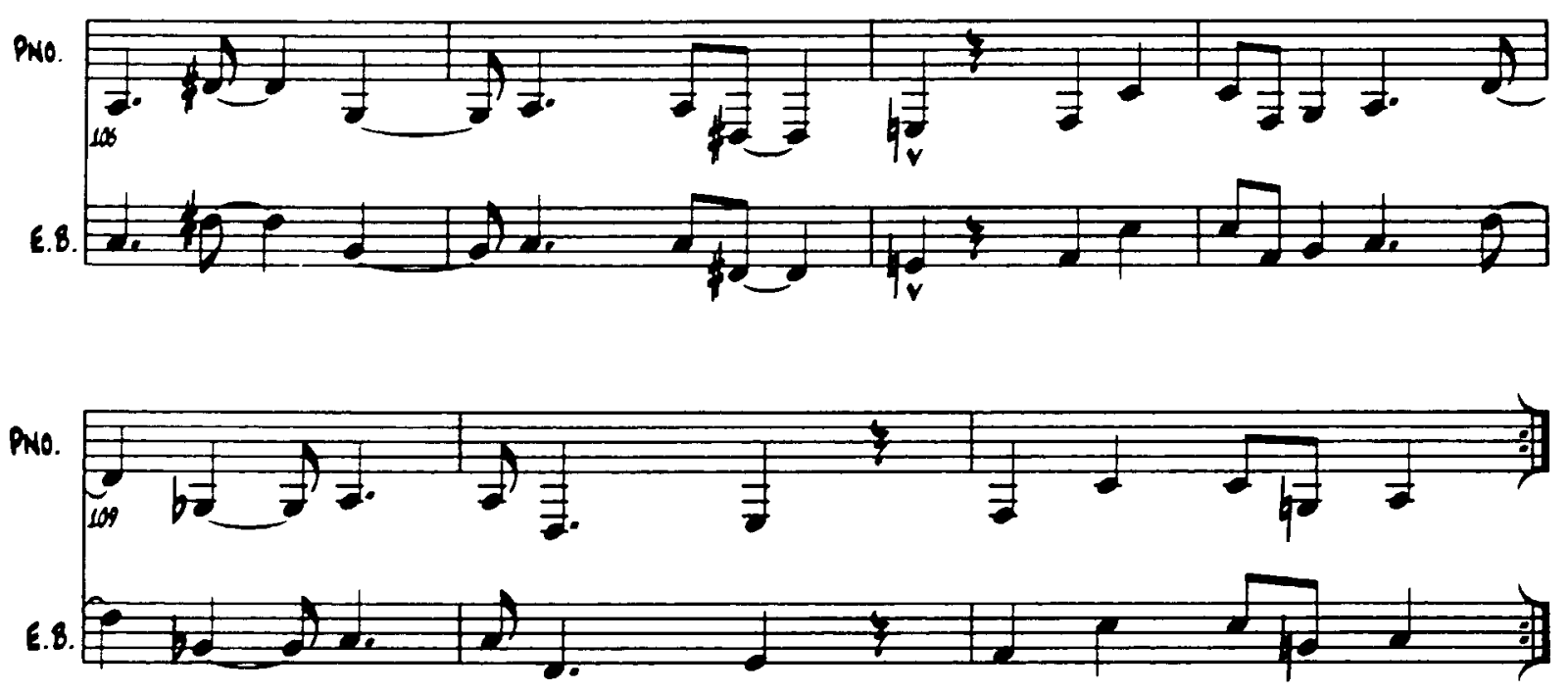

57 
(A)
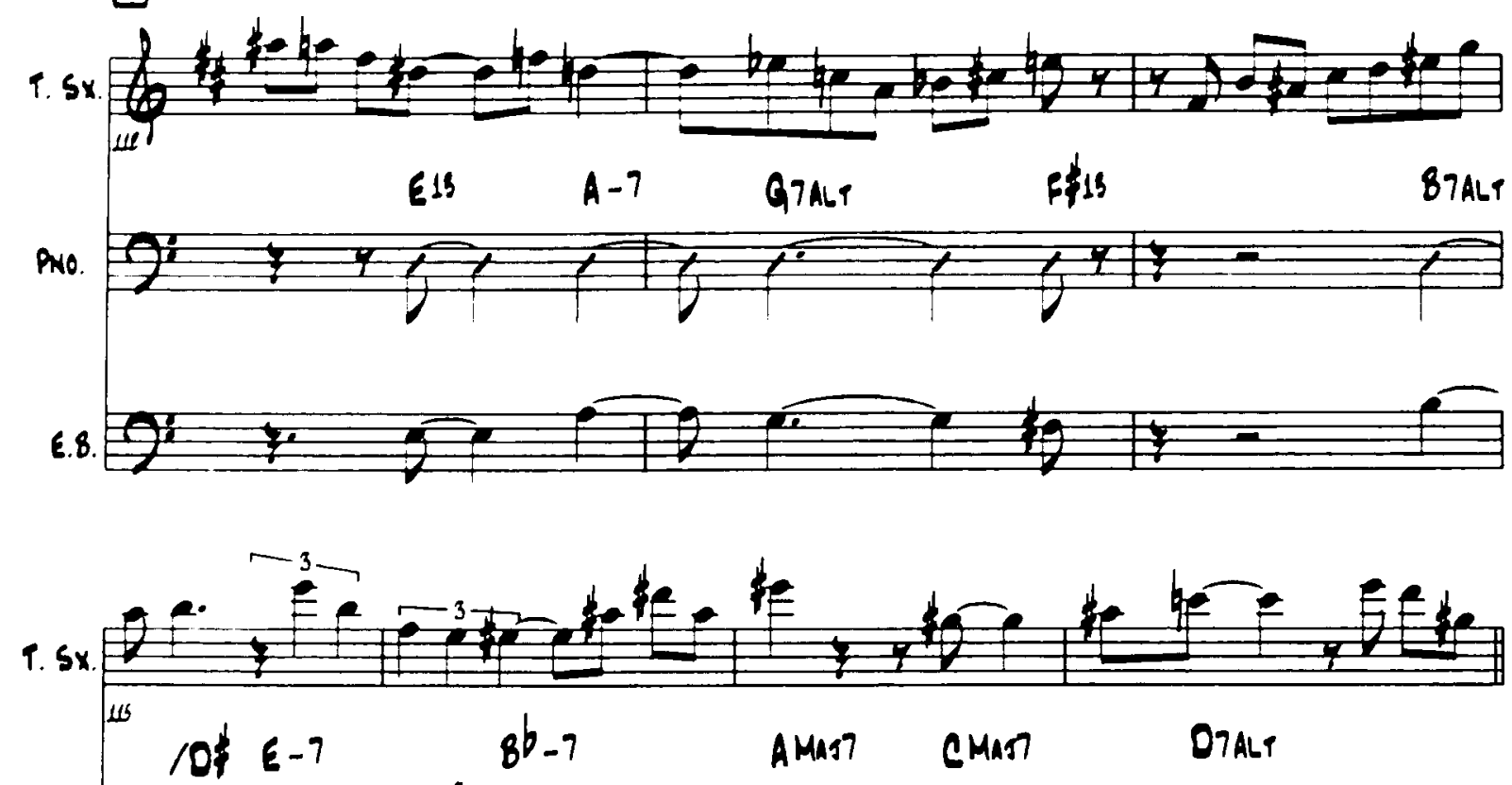

PNo.
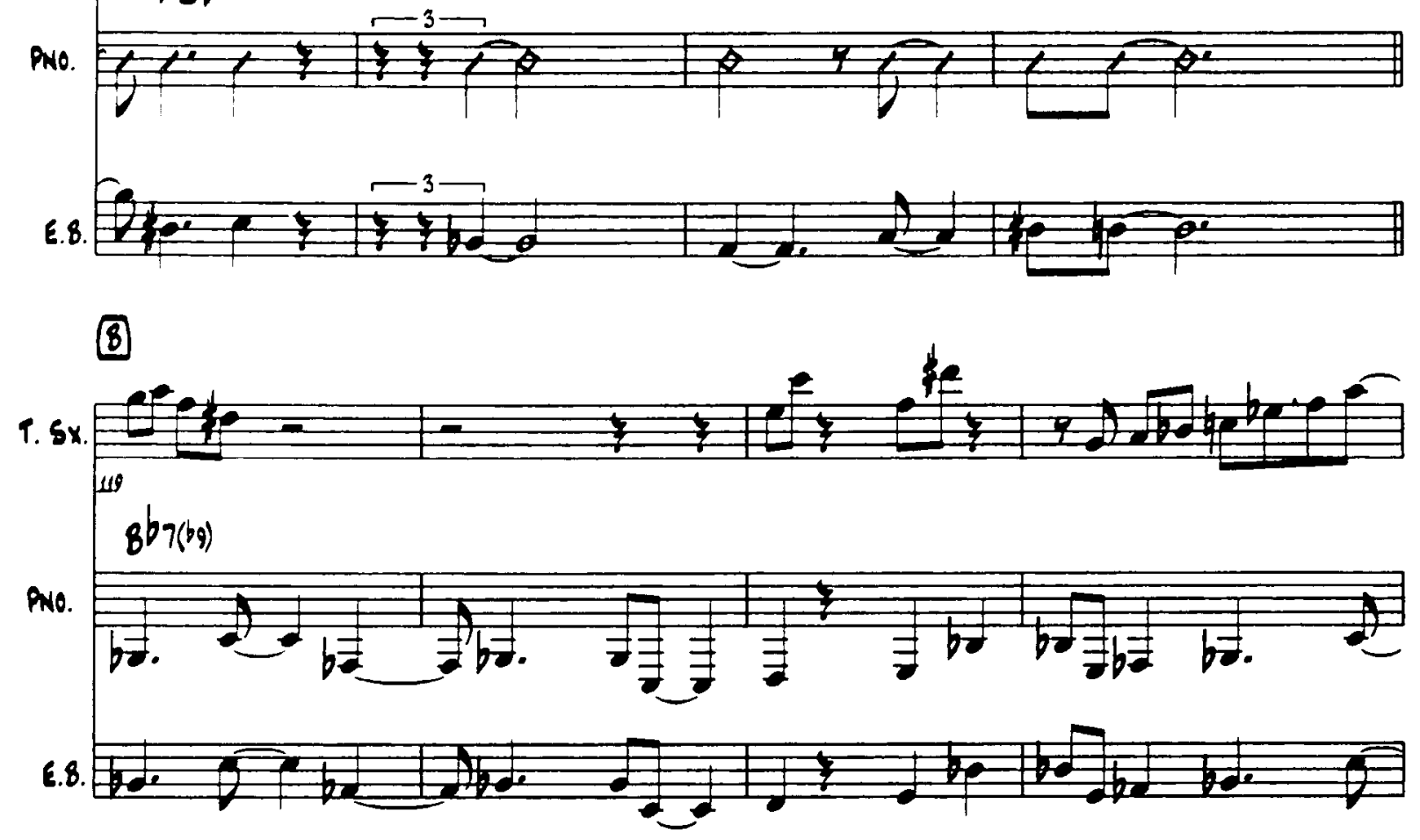


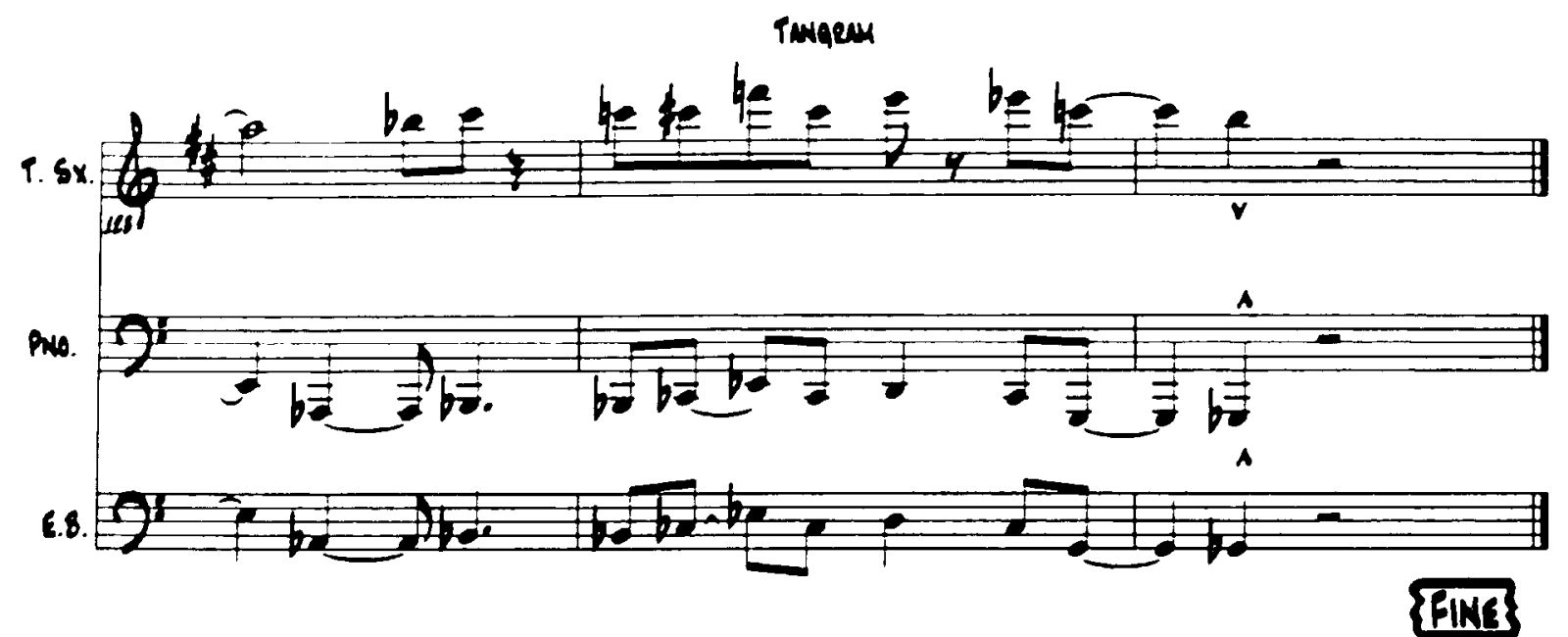

59 


\section{Katuega}

RUSATO.

Aqusmin Cown
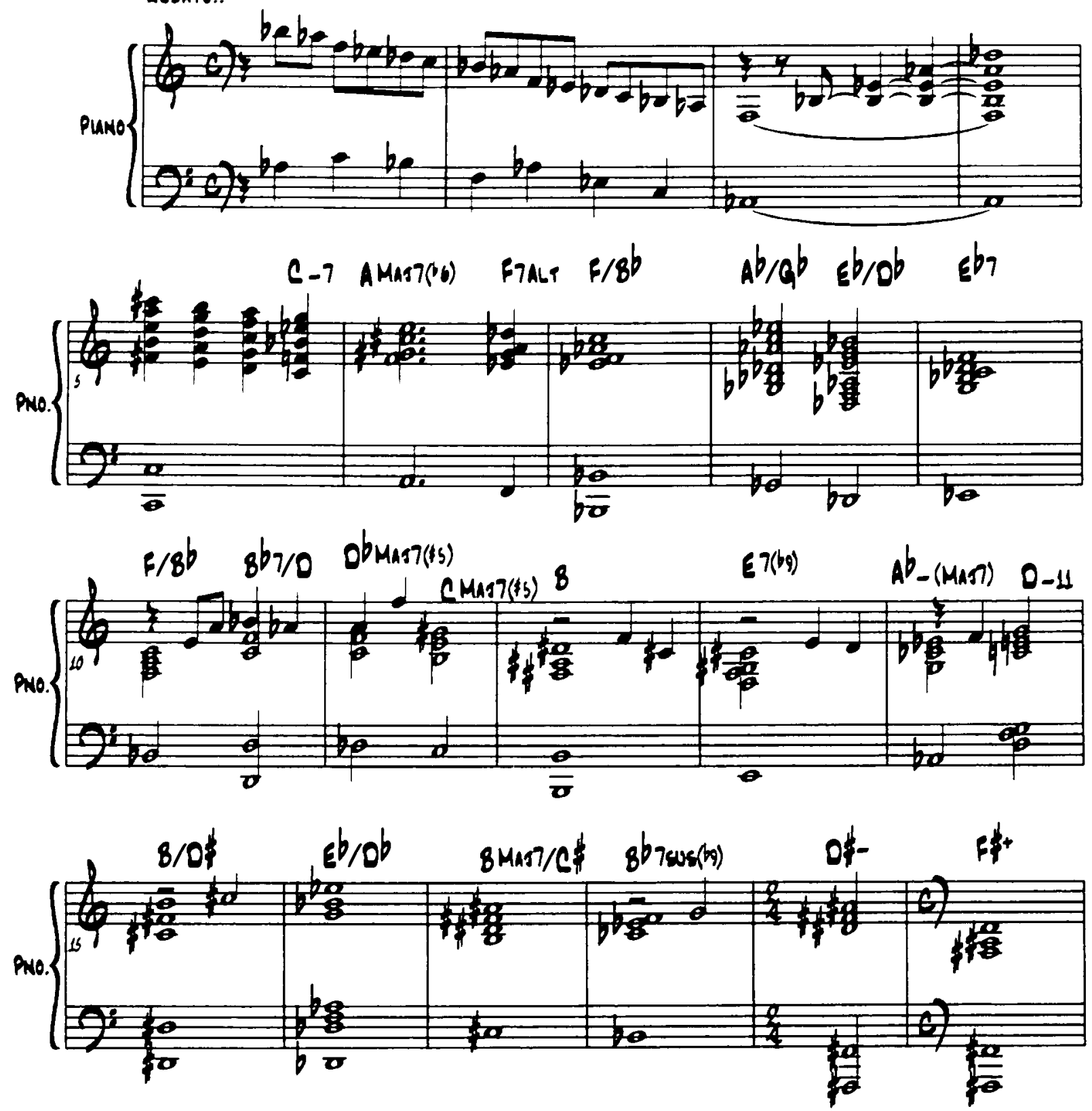


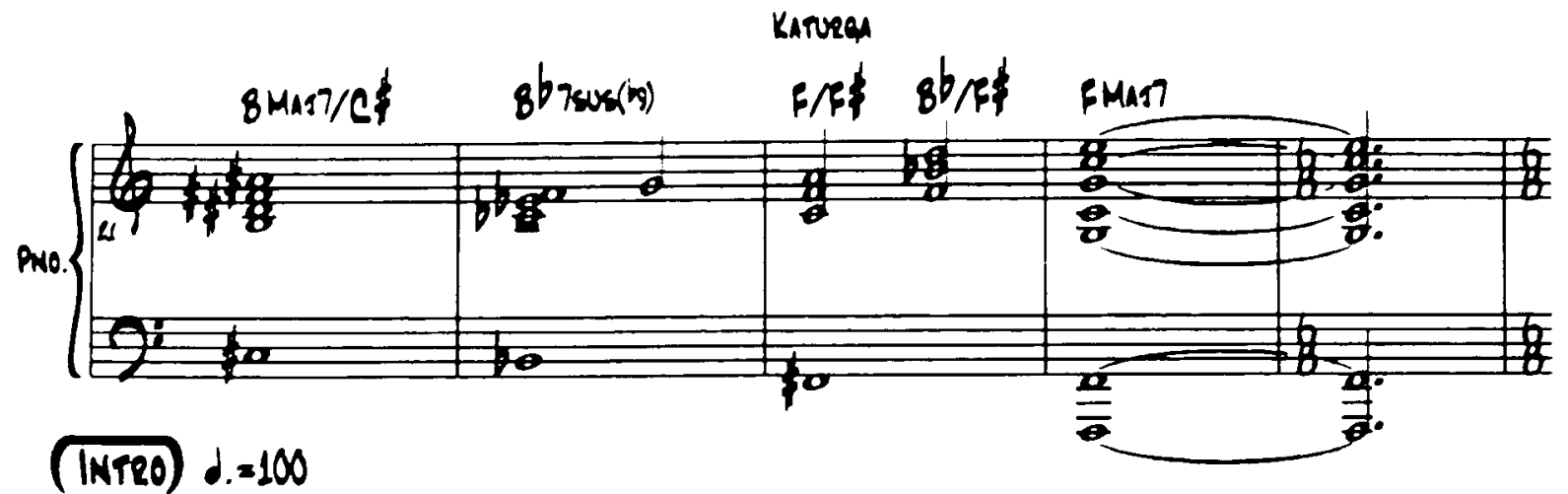

9.0.
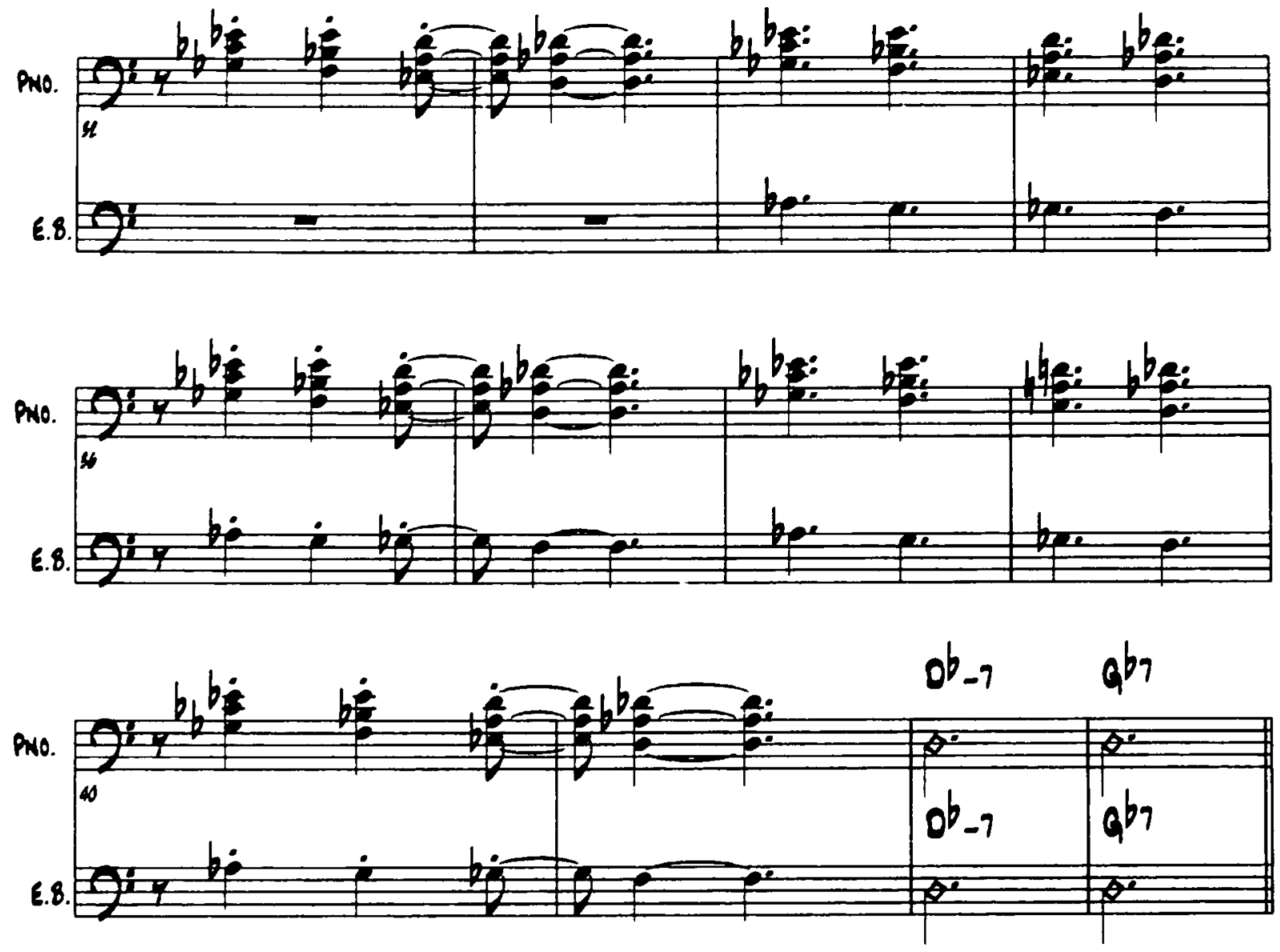

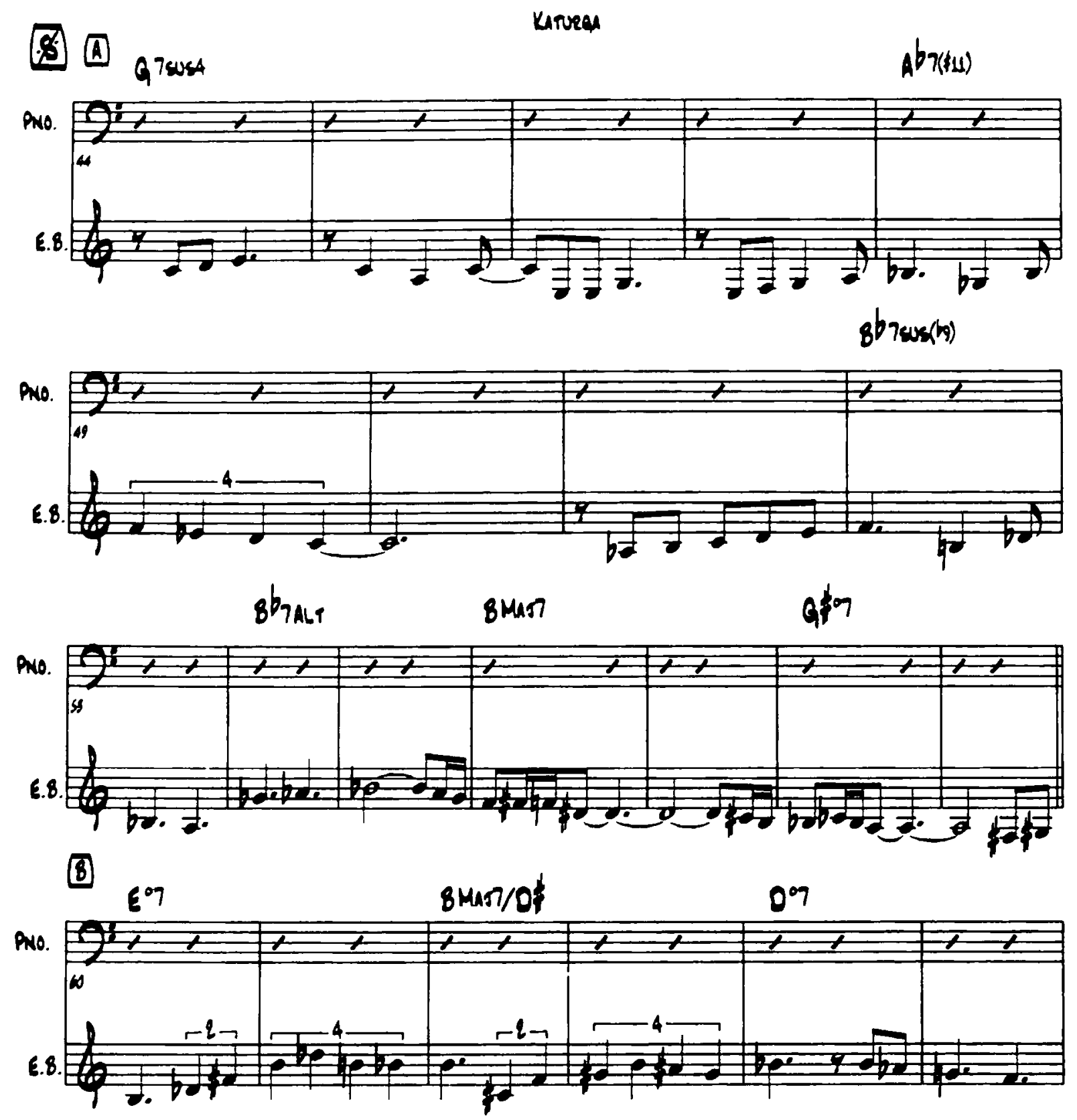


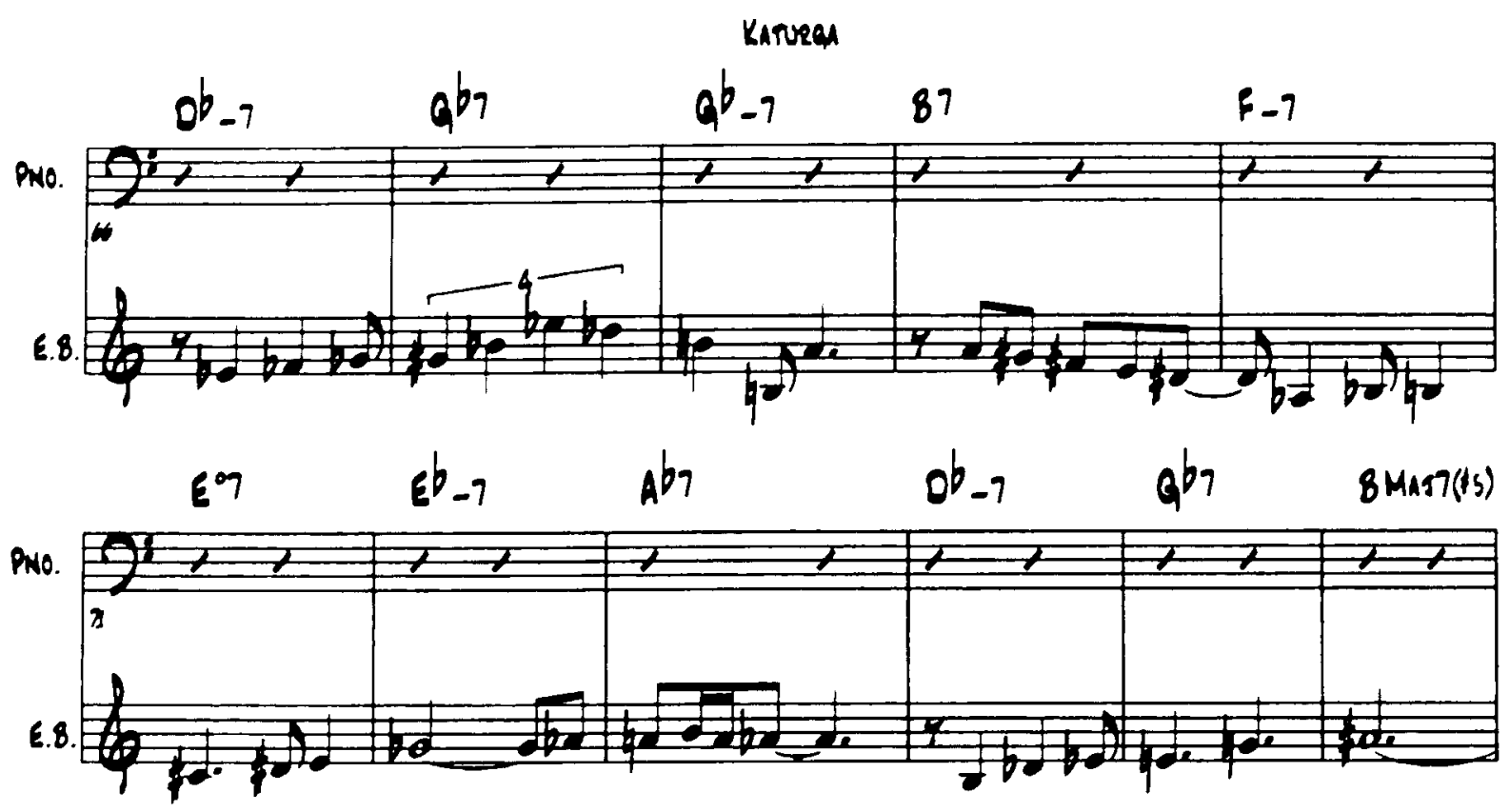

(C)

5. $5 x$

PNo.

6.8.
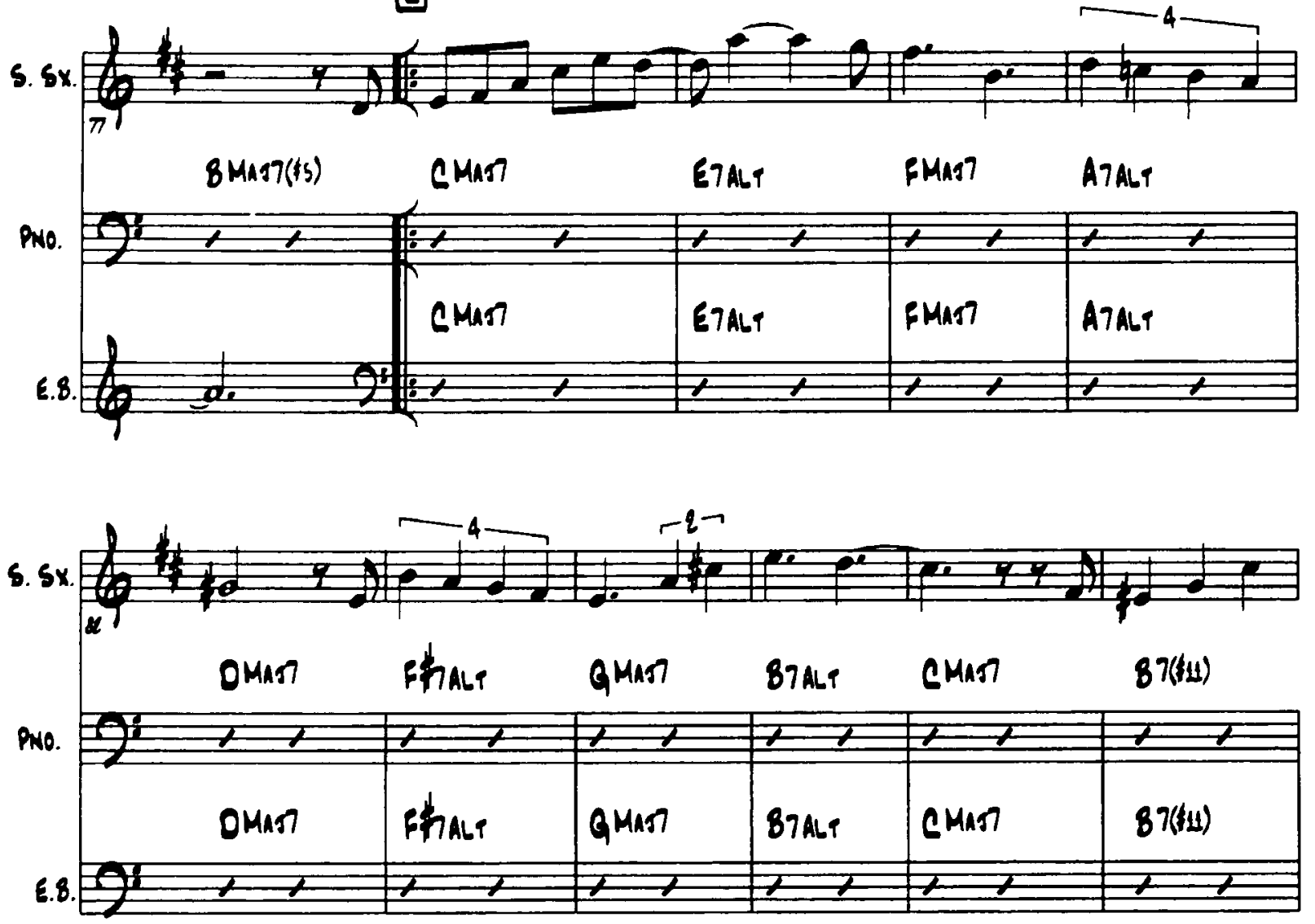

63 
Karveas

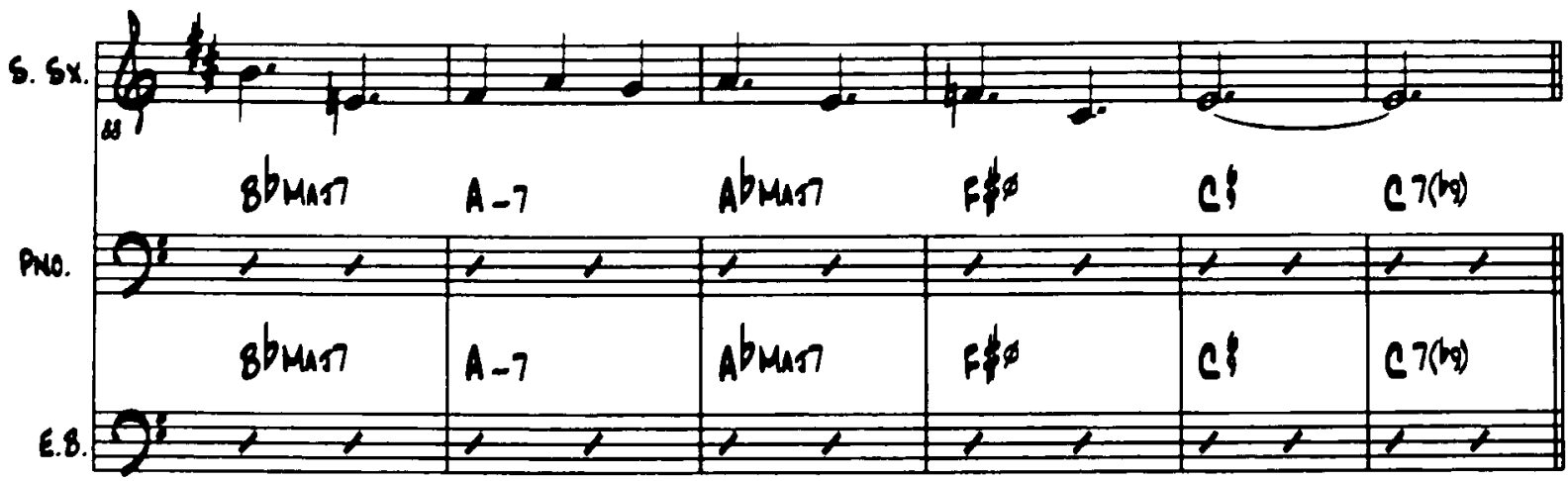

0

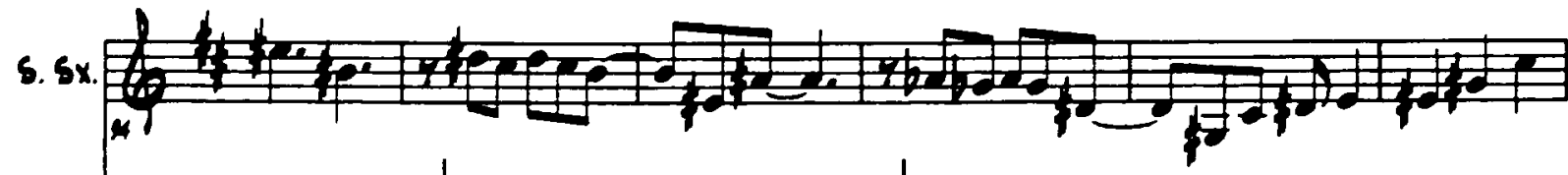

\begin{tabular}{|c|c|c|c|c|c|c|}
\hline & 8 MAn & ebyar & EMart & Abrace & Q Marf & EMaन7 \\
\hline & $x x$ & 7 & 7 & 7 & $x$ & 7 \\
\hline & 8MAT & Ehap & EMart & Abar & QMart & EMast \\
\hline & 71 & 7 & $x$ & $x$ & 7 & 7 \\
\hline
\end{tabular}

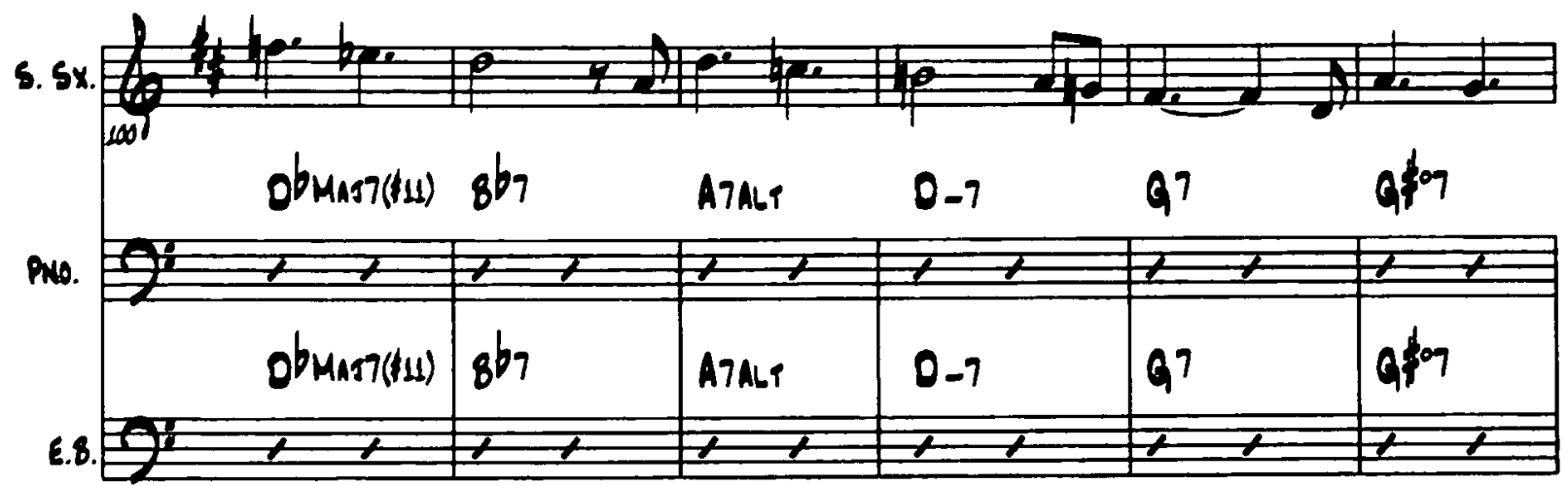


Kanveas
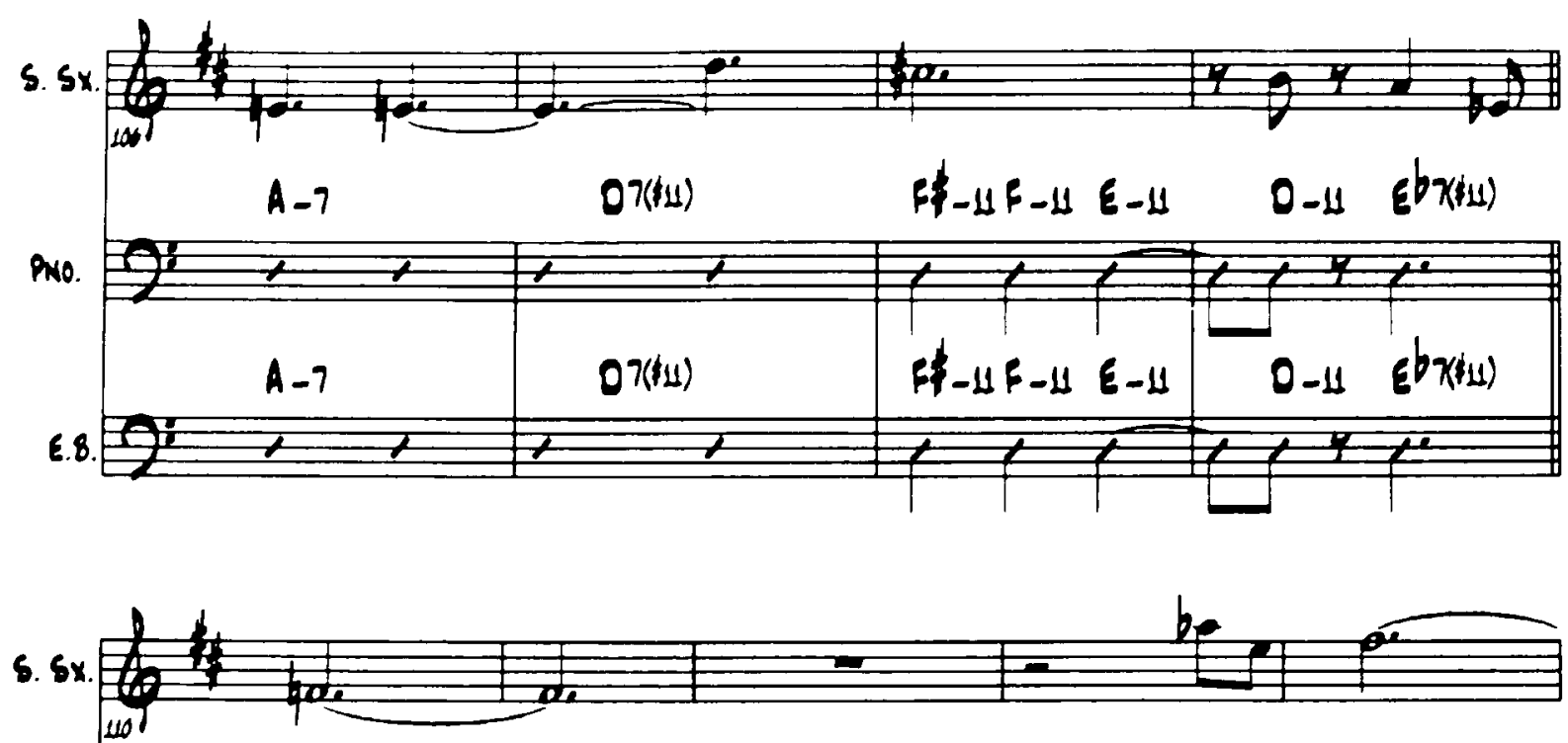

no.
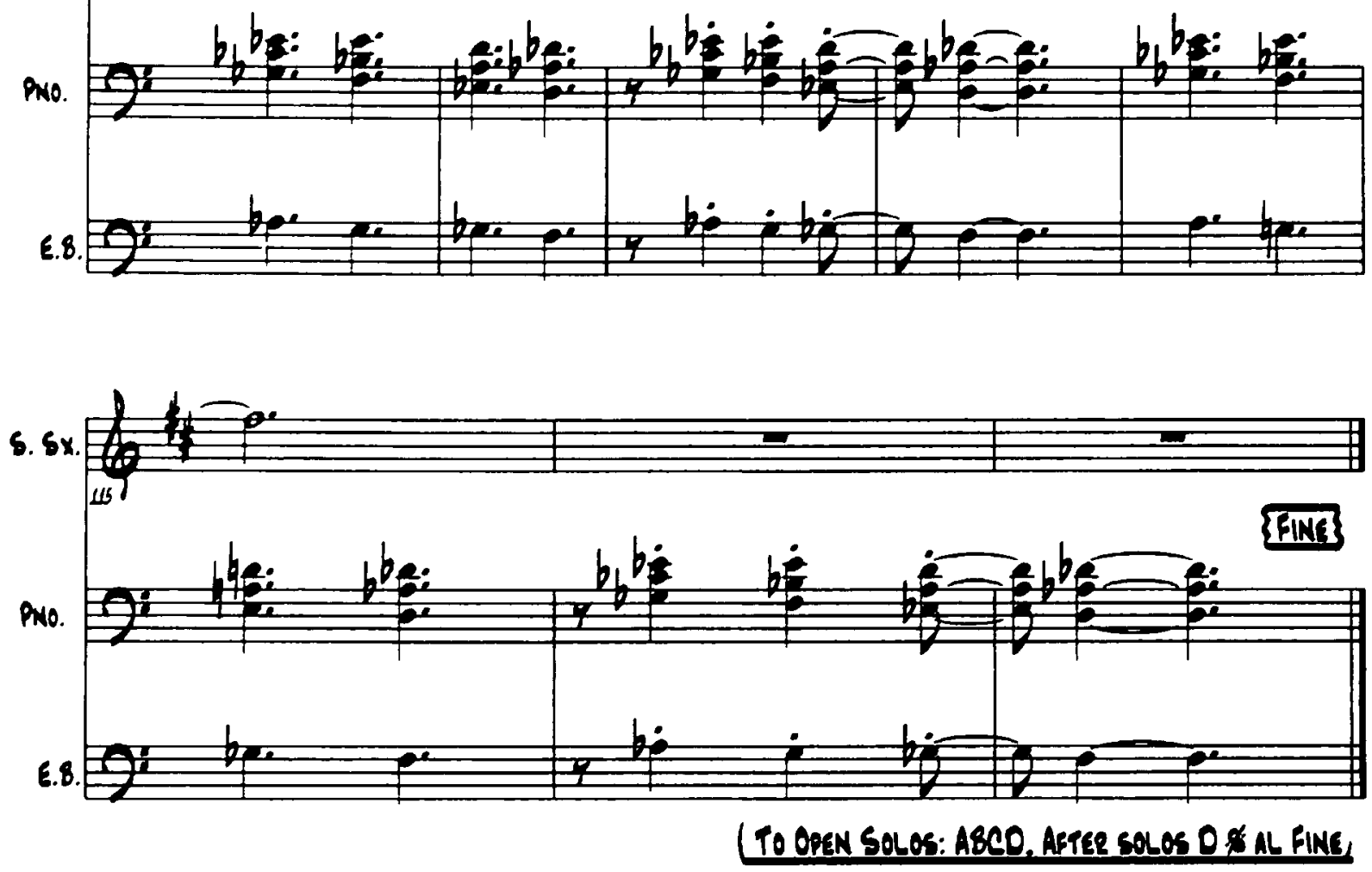


\section{Omotesandoo}

(GHacherer ferl)

Raustin Cown

(Com nam)

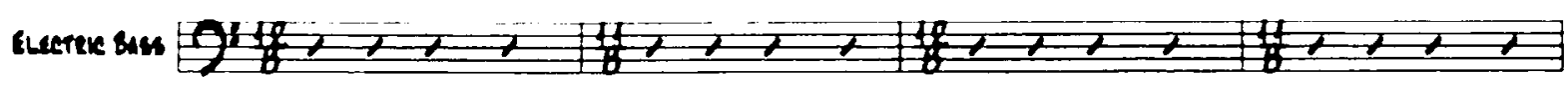

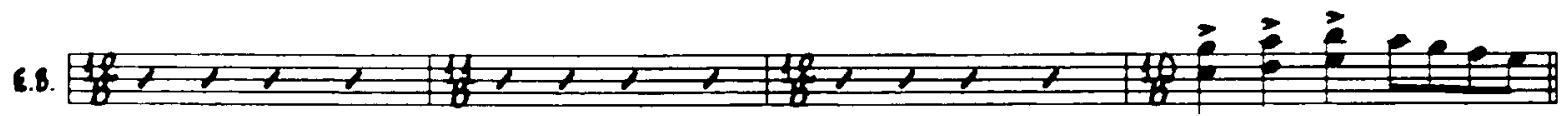
(NT⿱卄一)

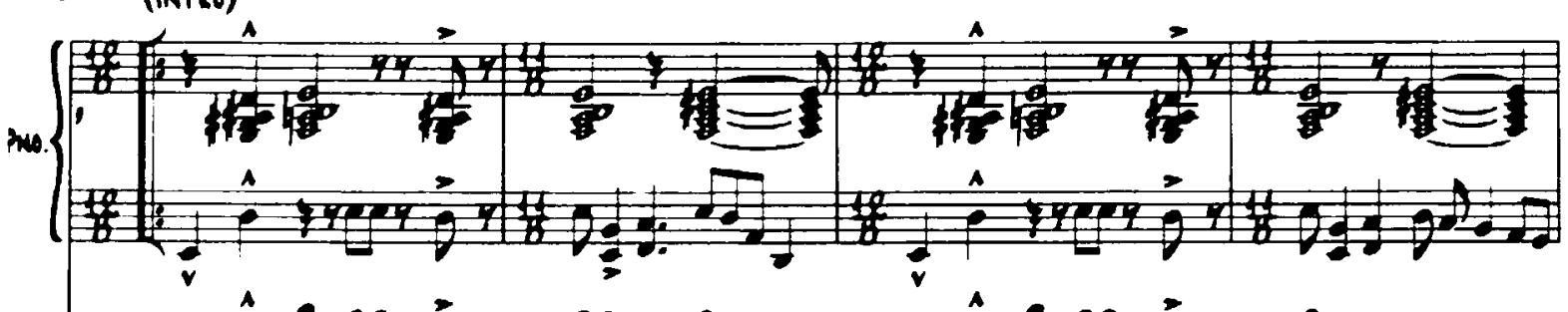

6.8.

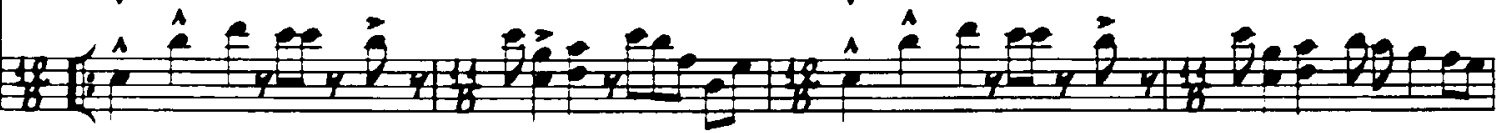

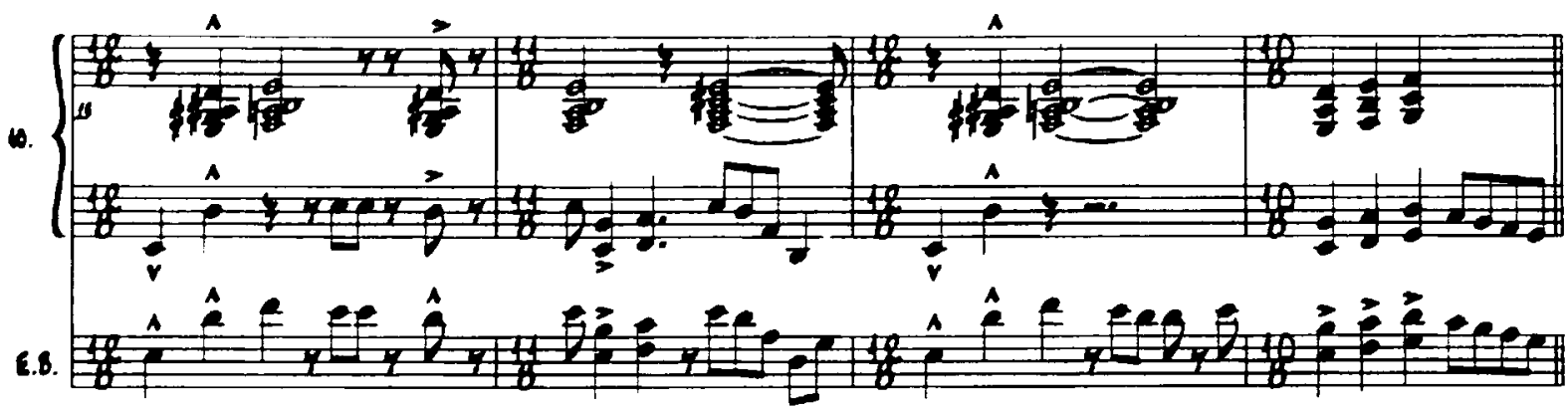


(1)
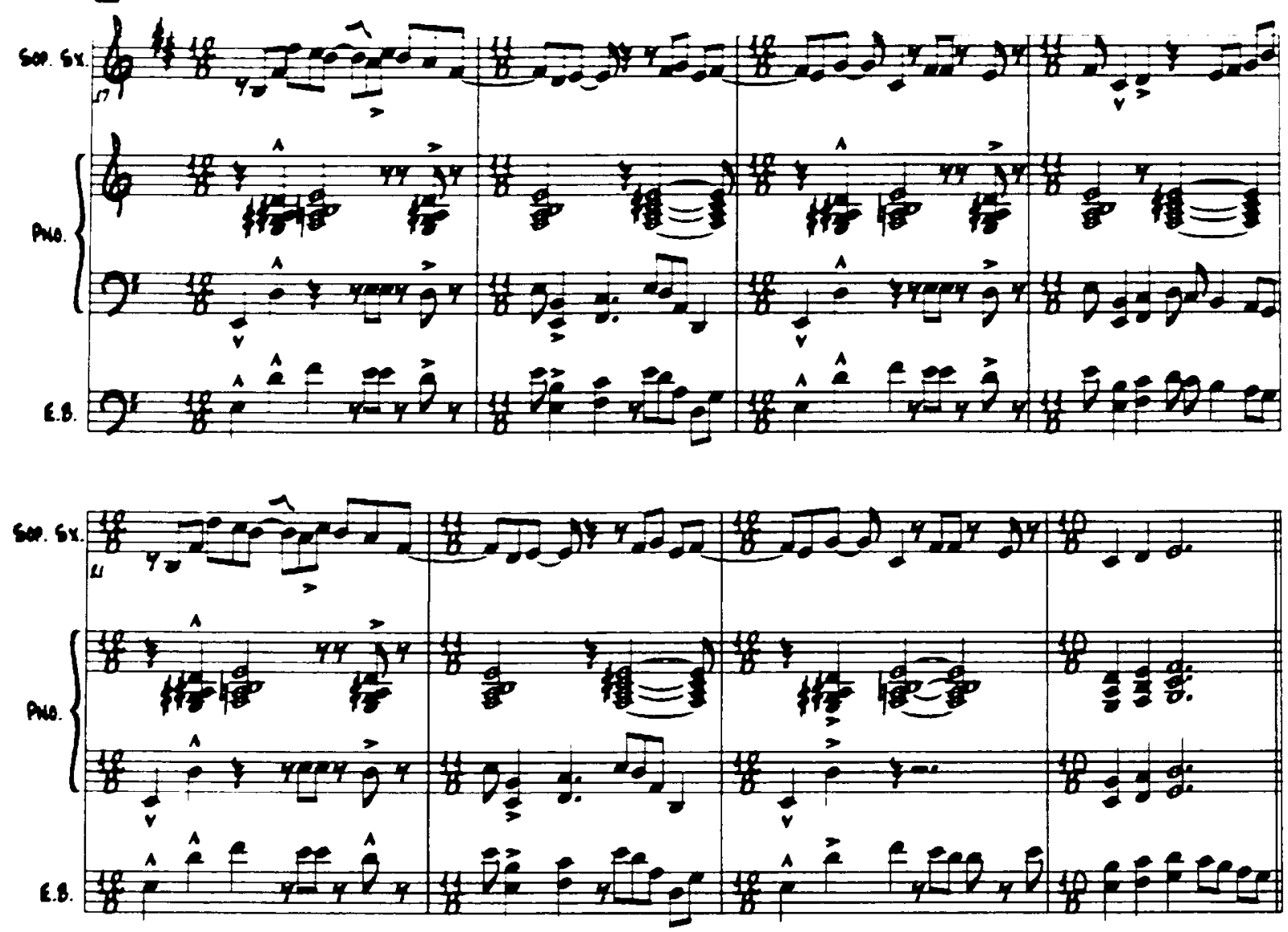

(b)

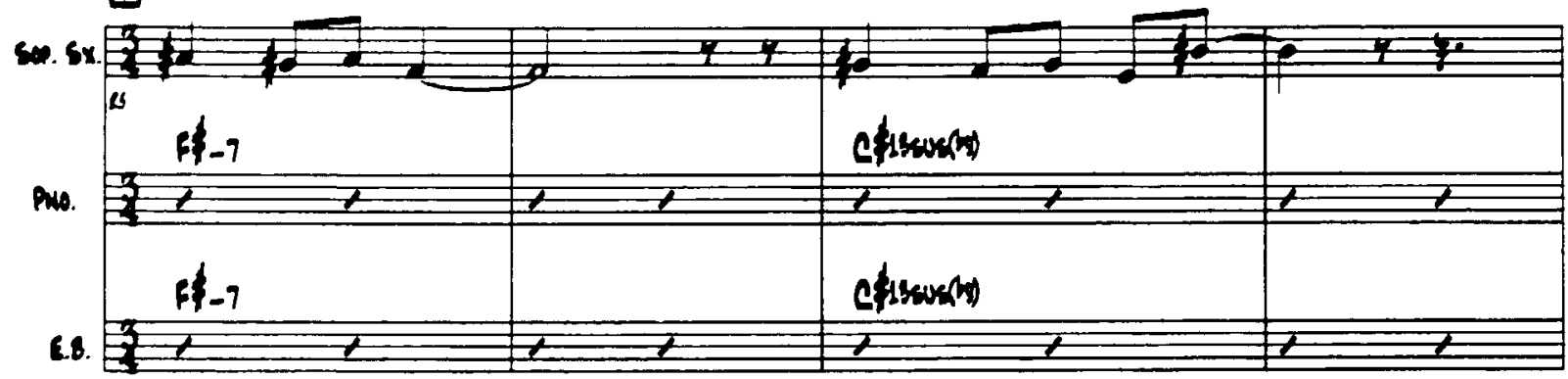


aneresuros
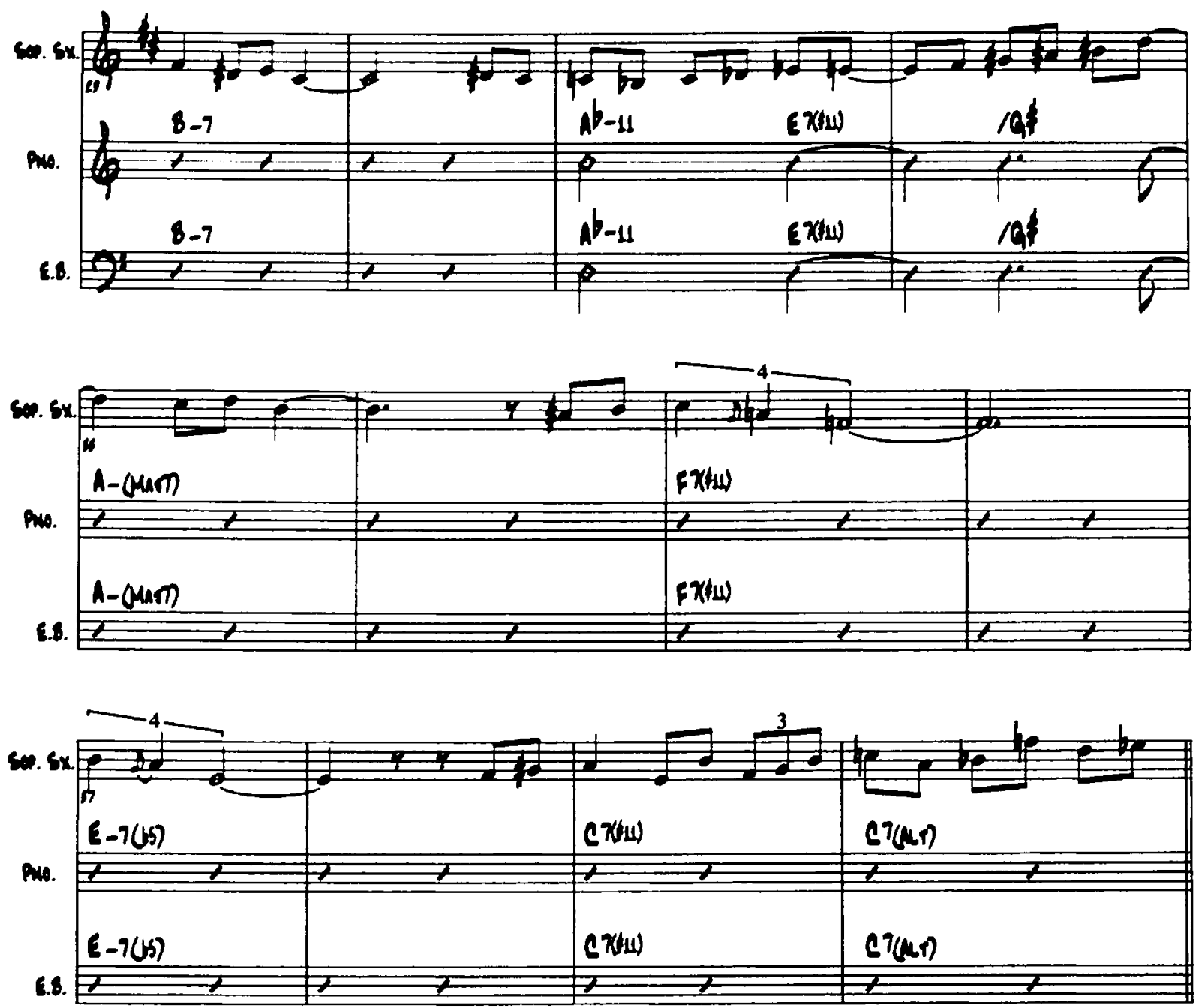

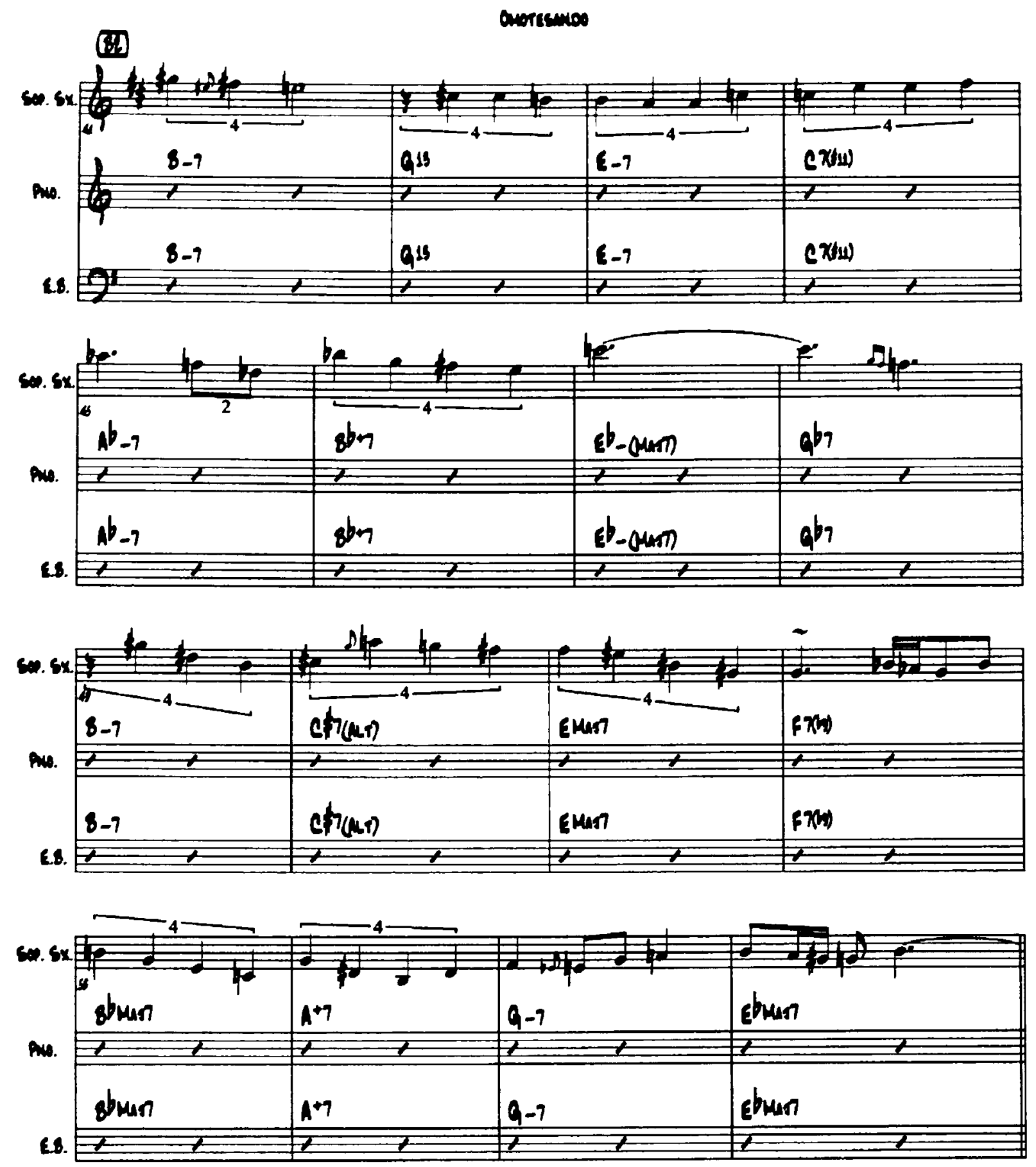

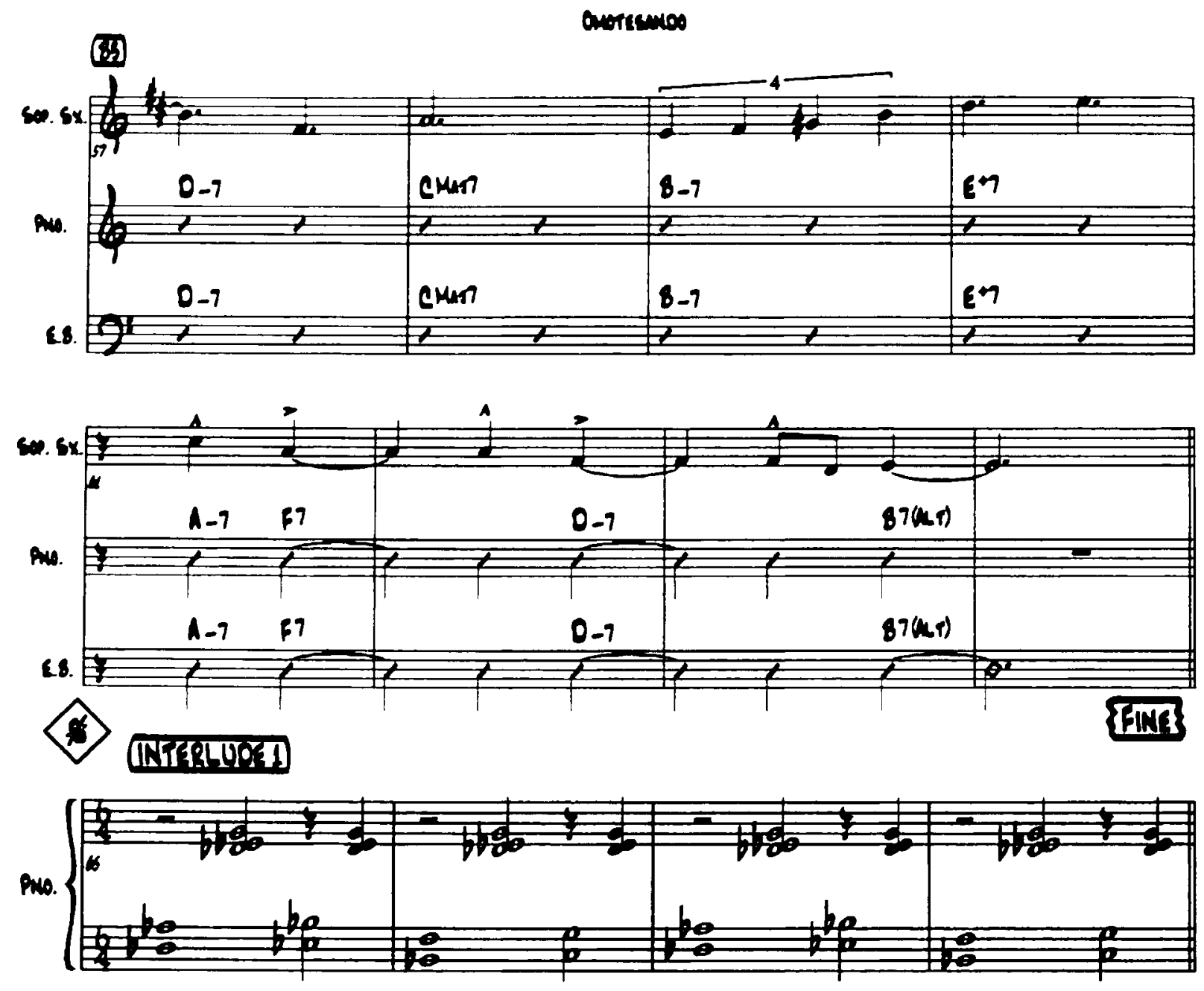
(c)

anersendos

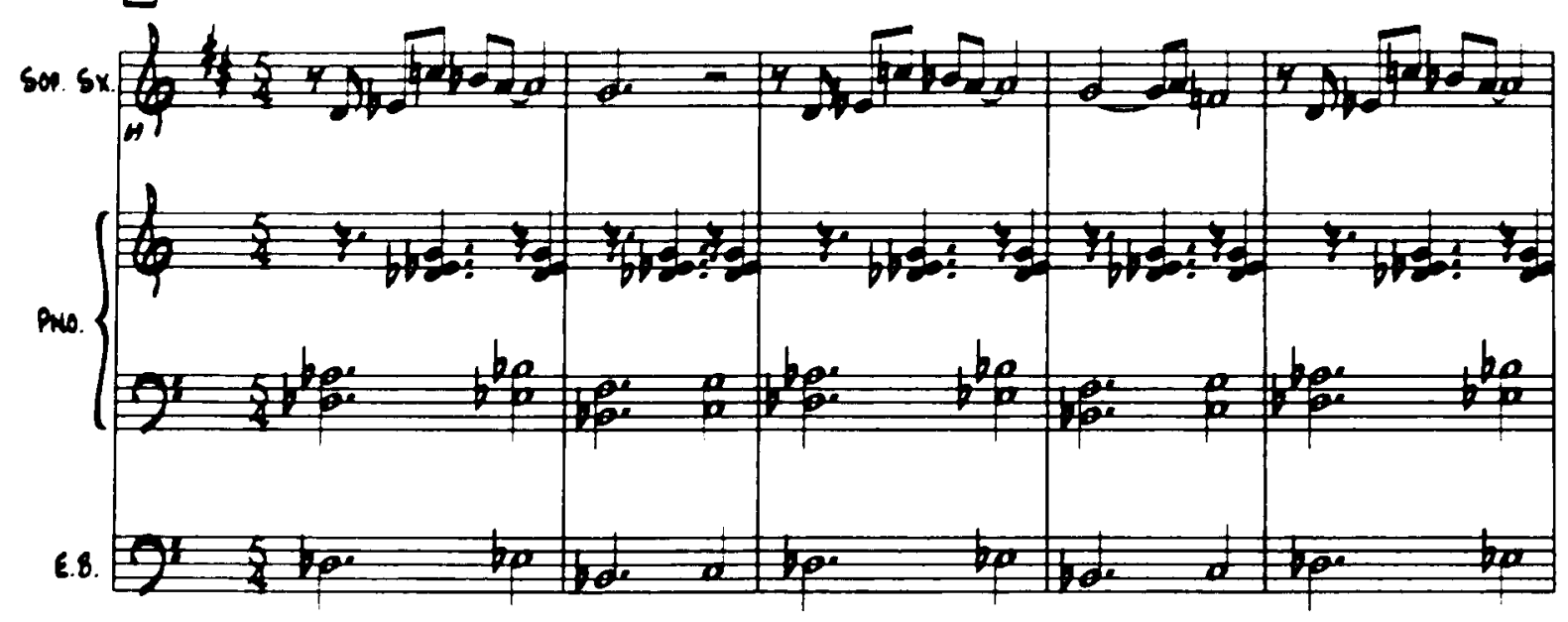

(0)

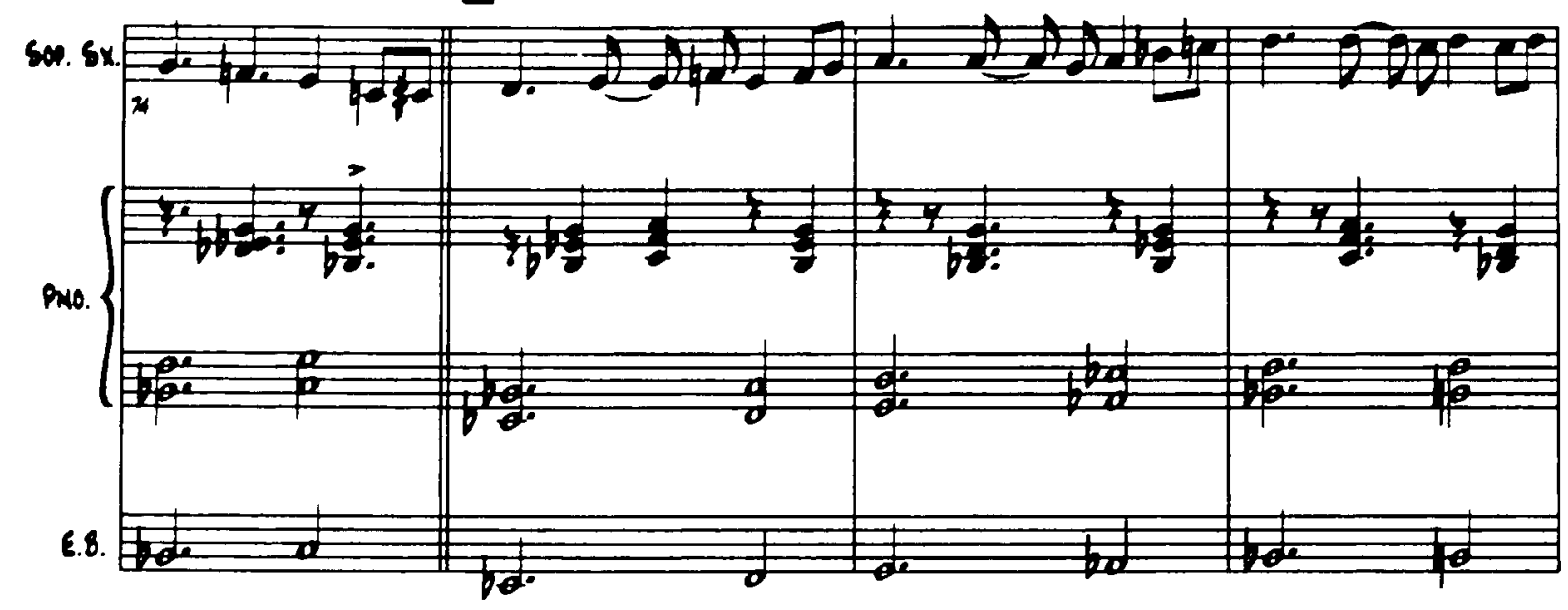


ancesuros
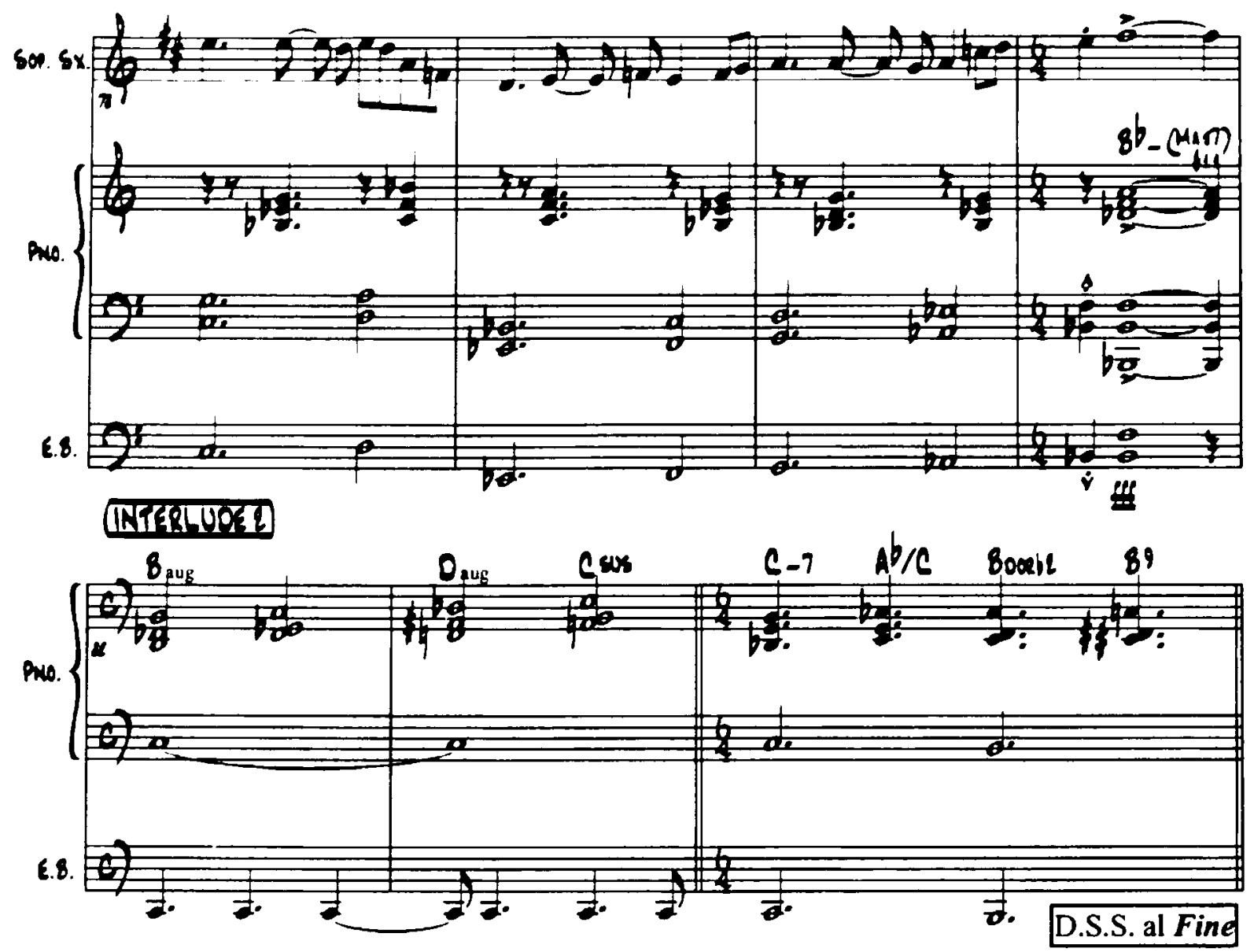

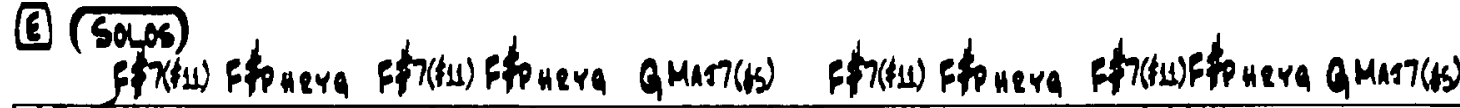

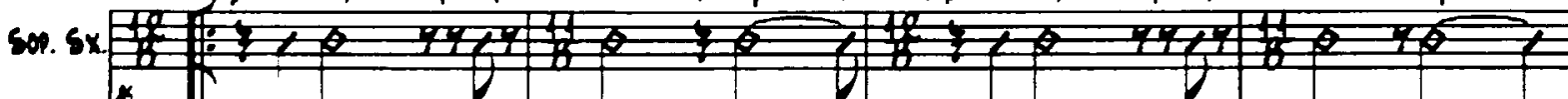

puo.

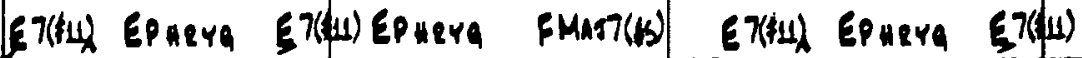

6.8. 
andernos
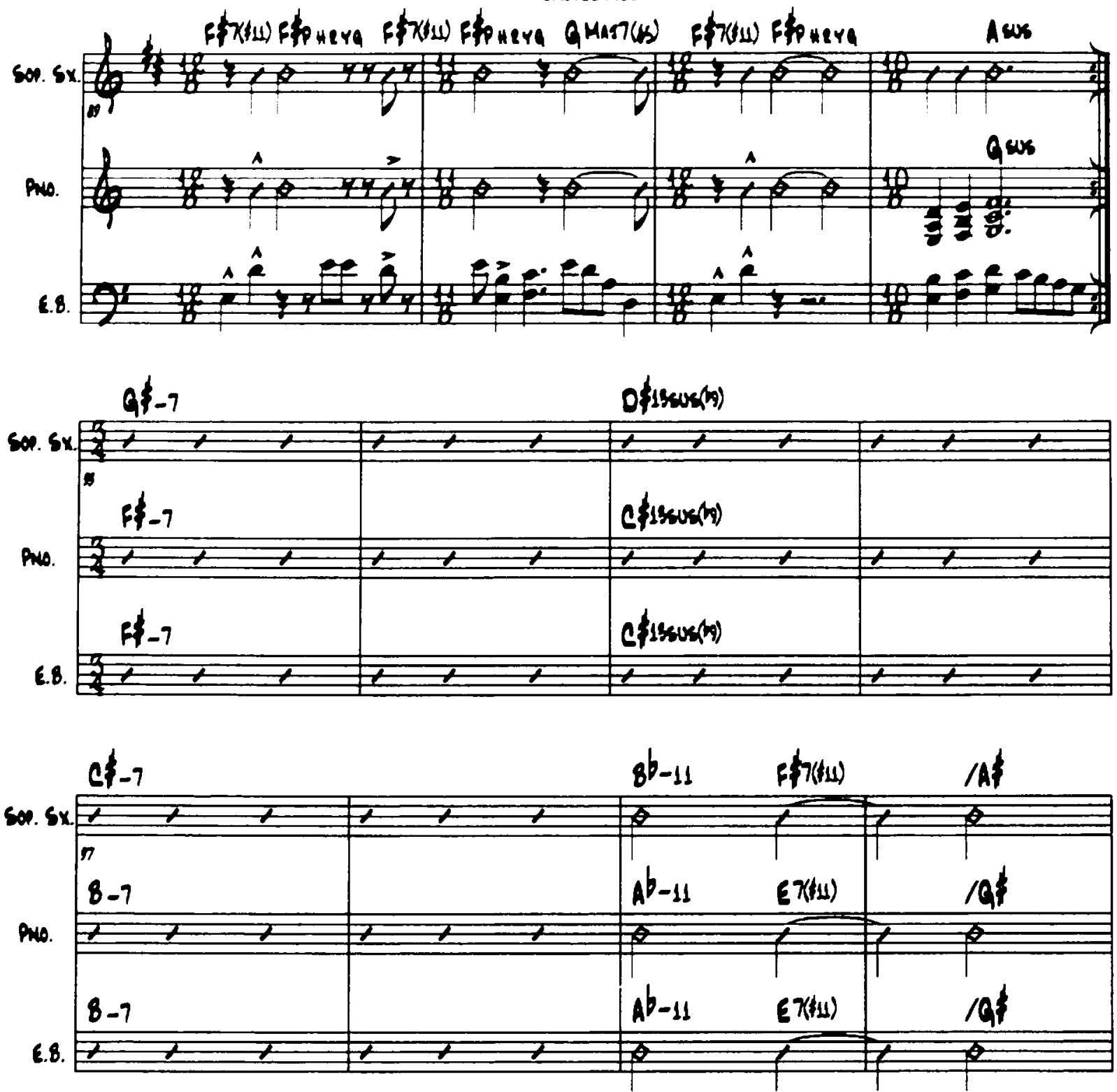
aneseresos
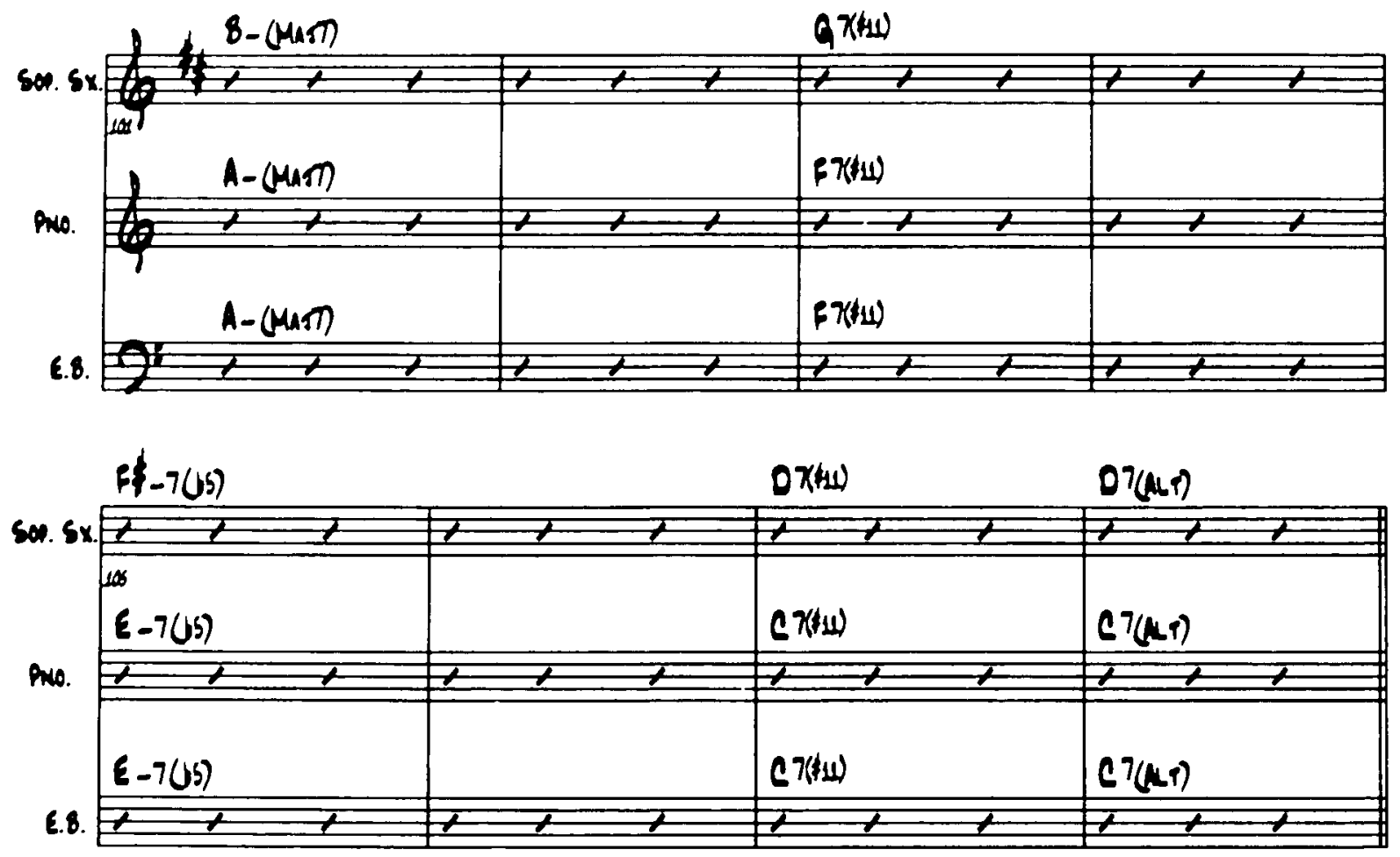

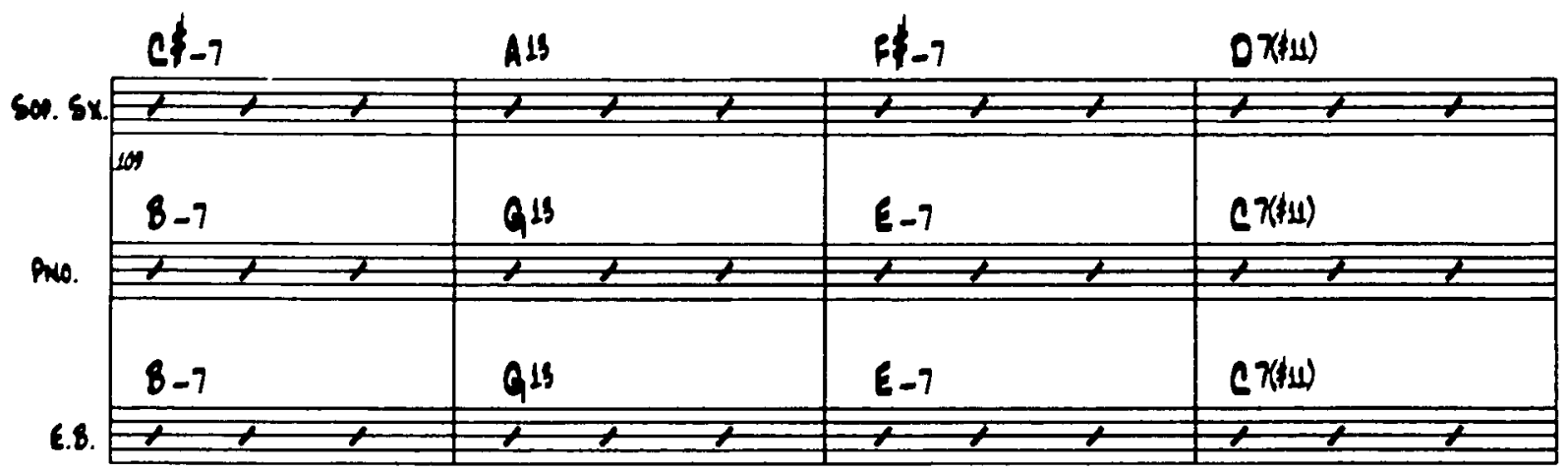


andesuros

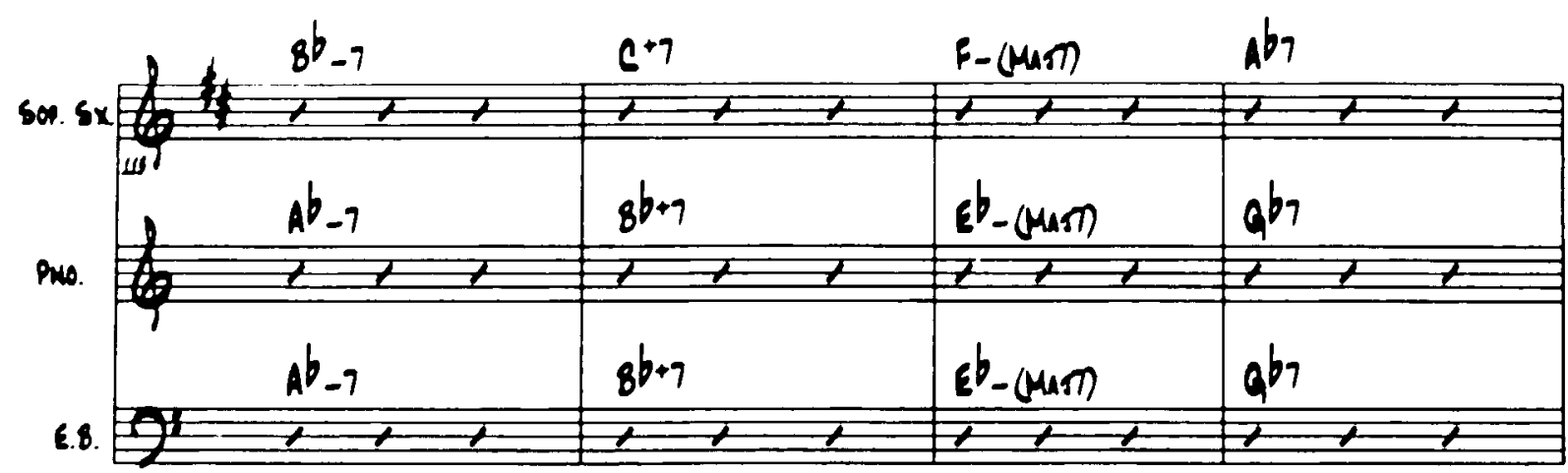

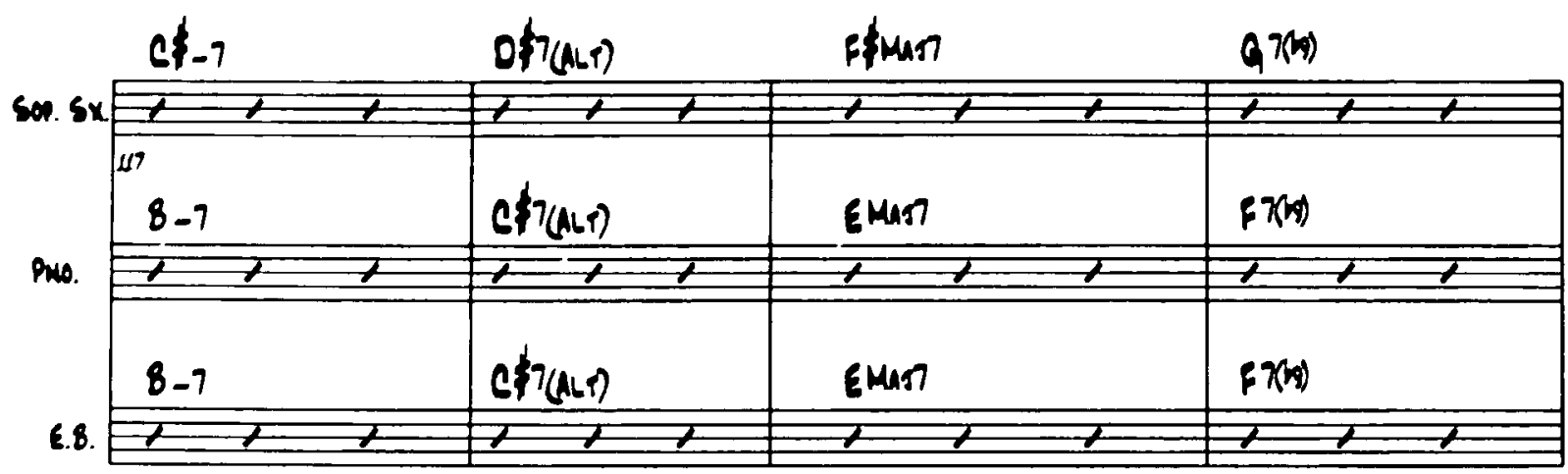

\begin{tabular}{|c|c|c|c|c|}
\hline & CMas? & $8+7$ & $A-7$ & FMan \\
\hline 500.5 & $x x x$ & $7 x$ & $x x$ & $x_{x}$ \\
\hline & 86 mant & $A^{+7}$ & $a-7$ & Ebmast \\
\hline Pro. & 2 & 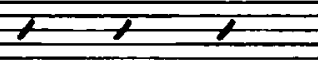 & $g x$ & $7 x$ \\
\hline & Bbmat & $A+9$ & $a-7$ & Ebant \\
\hline 6.8. & $x=$ & $7 x$ & $z$ & $z$ \\
\hline
\end{tabular}




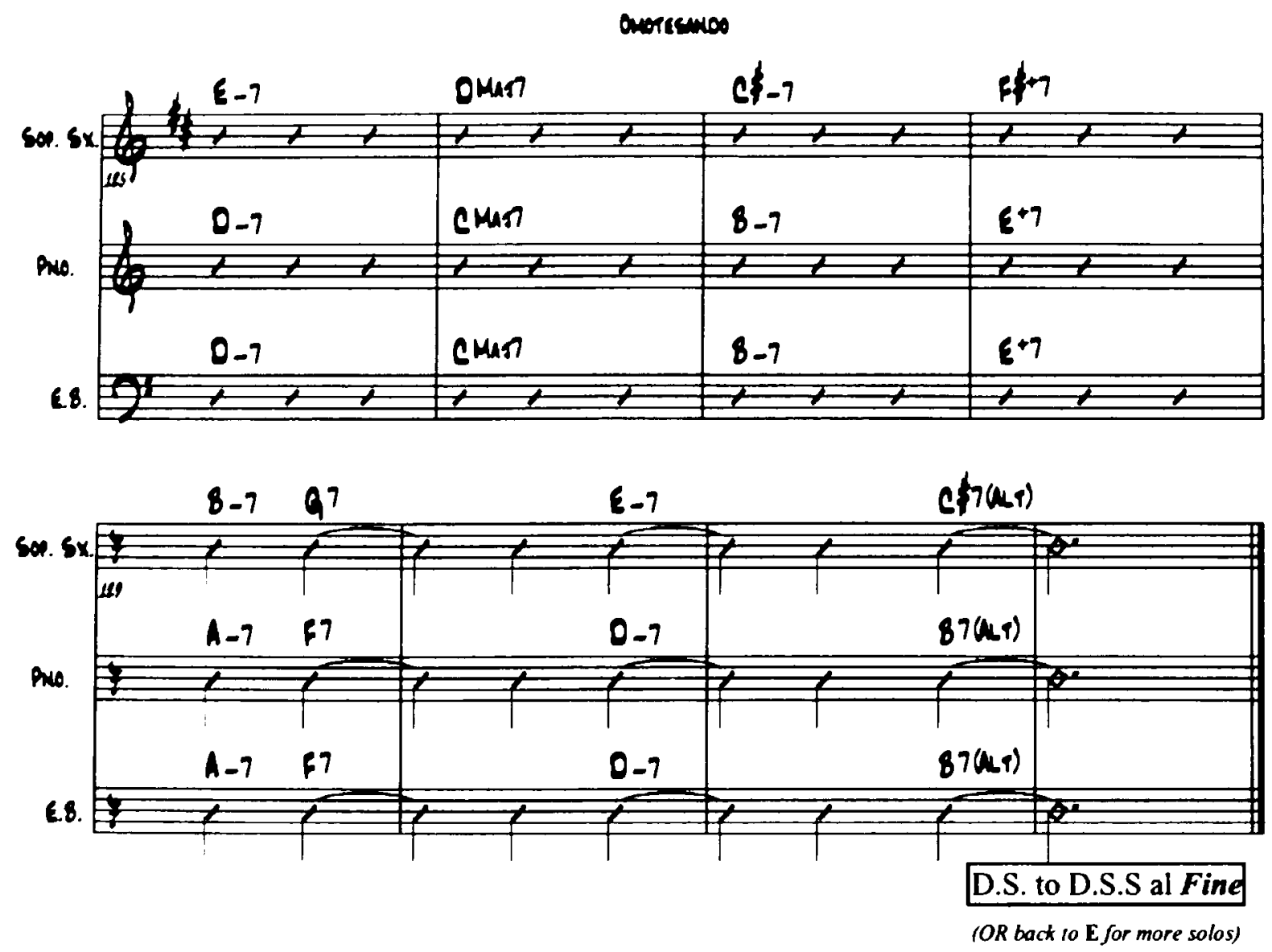




\section{forgos de Manizarniza}

$d=150$

Agustin Cown

(1)

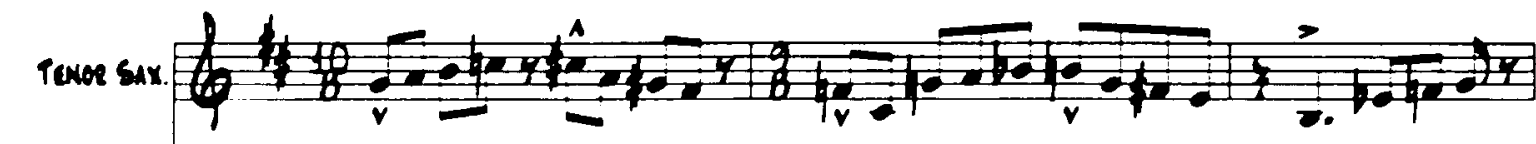

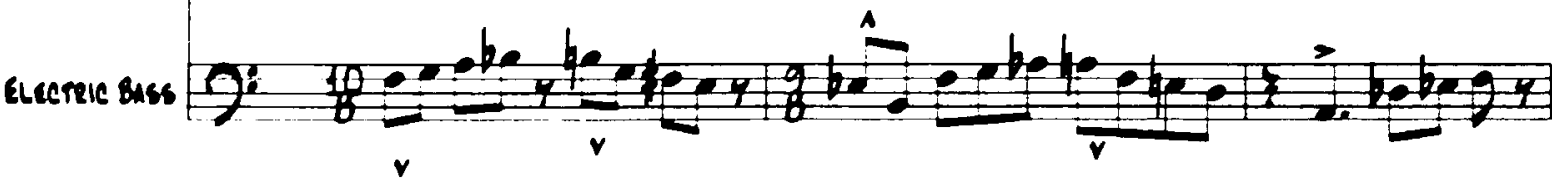

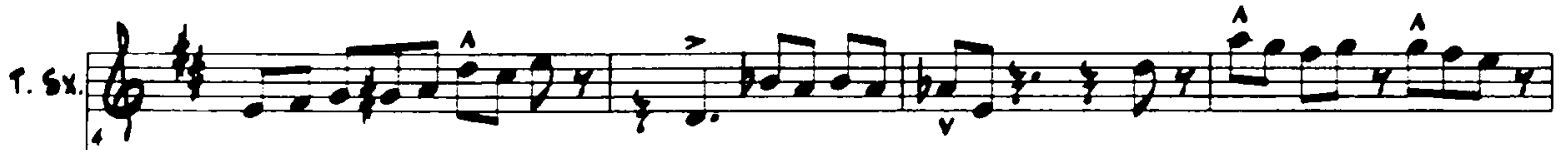

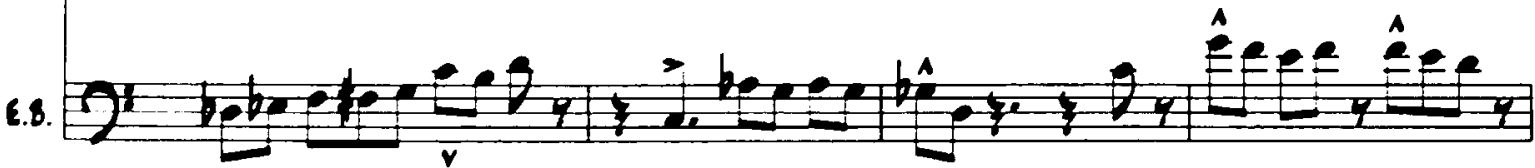

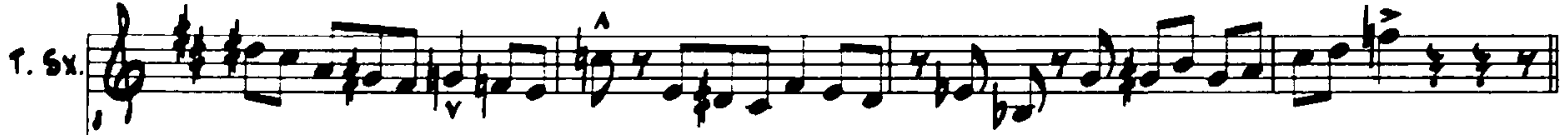

6.8.

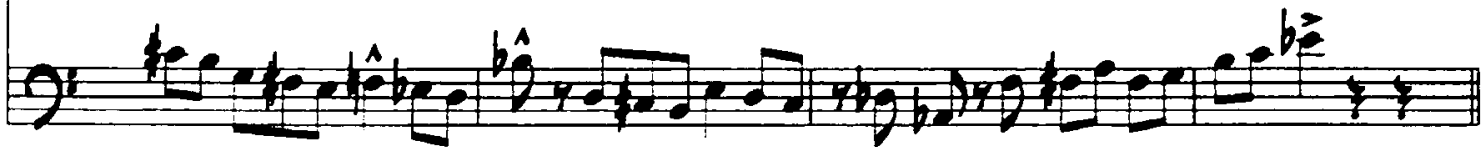


furass $\propto$ Manierevile
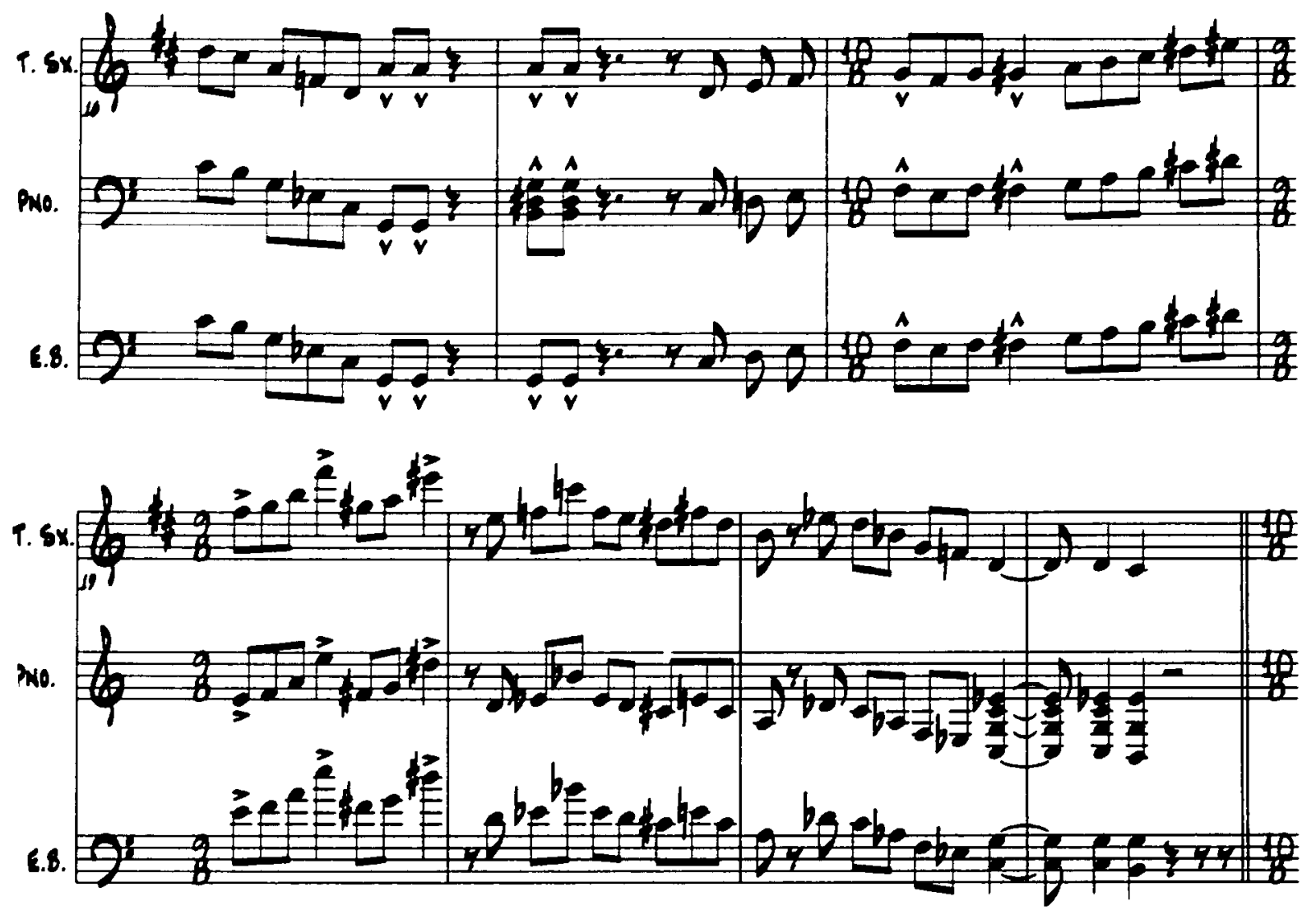

78 

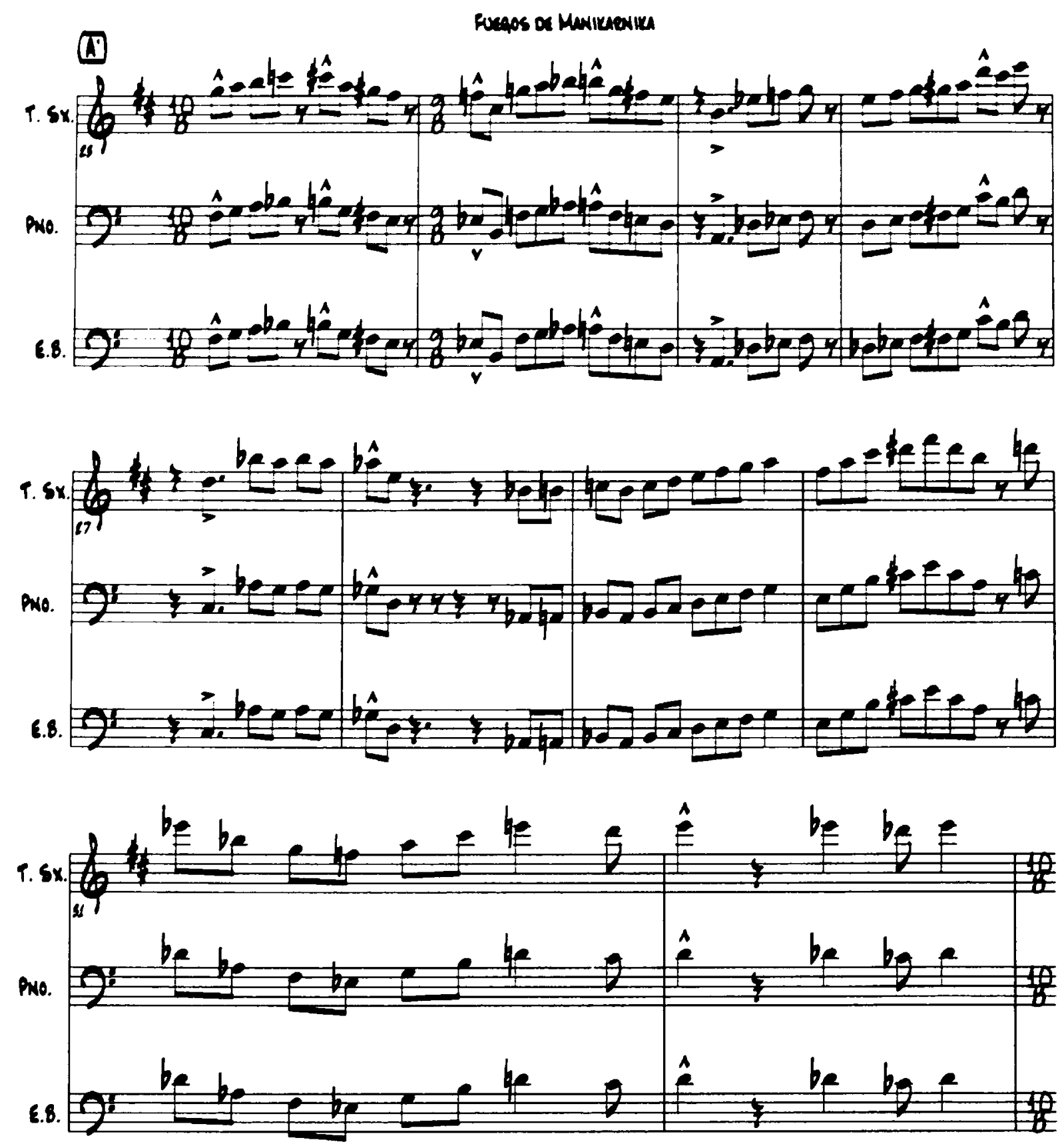
foraps or Munizevilu

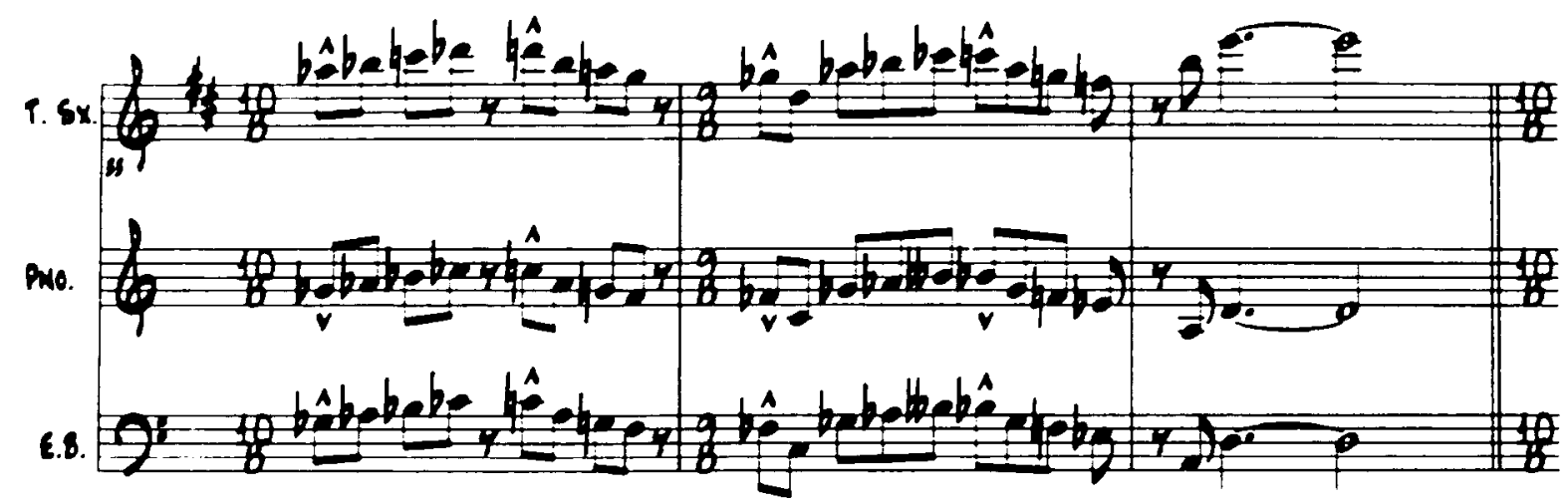
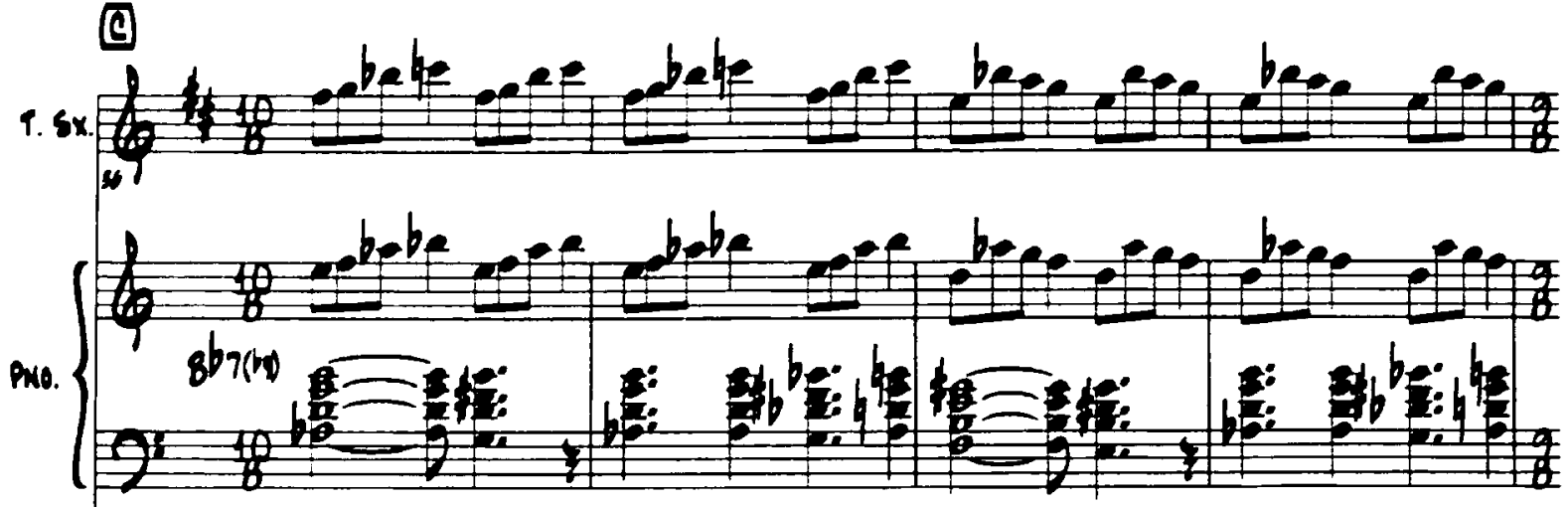

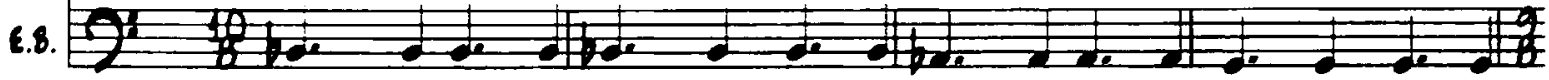

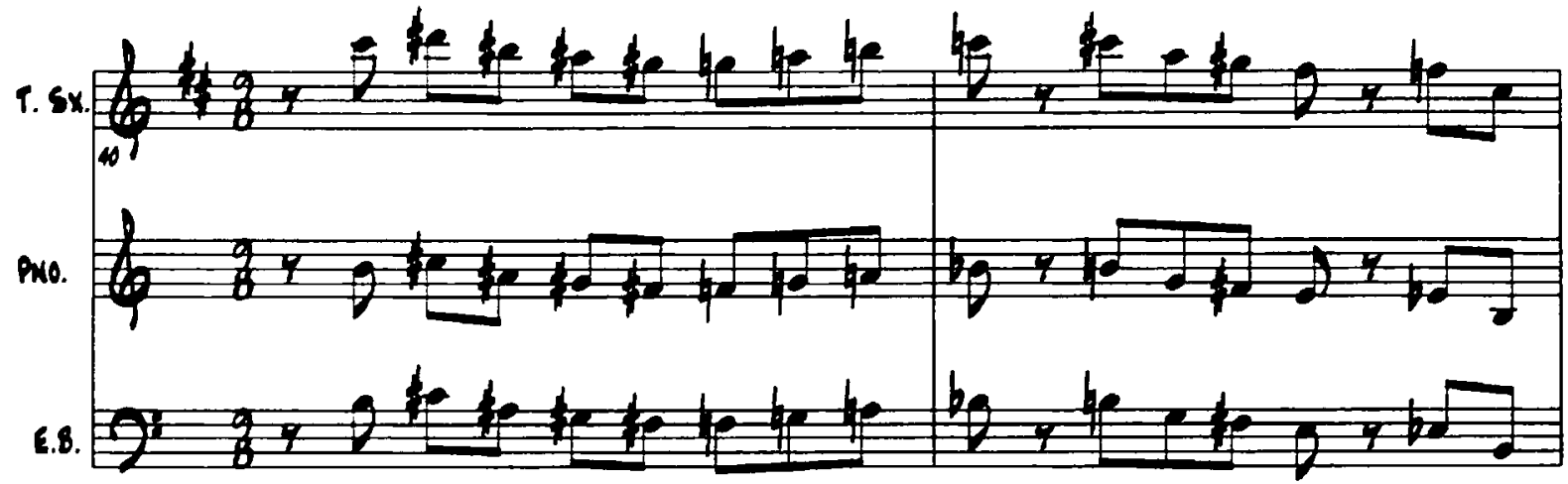


Fueaps ol Mavilueviliea
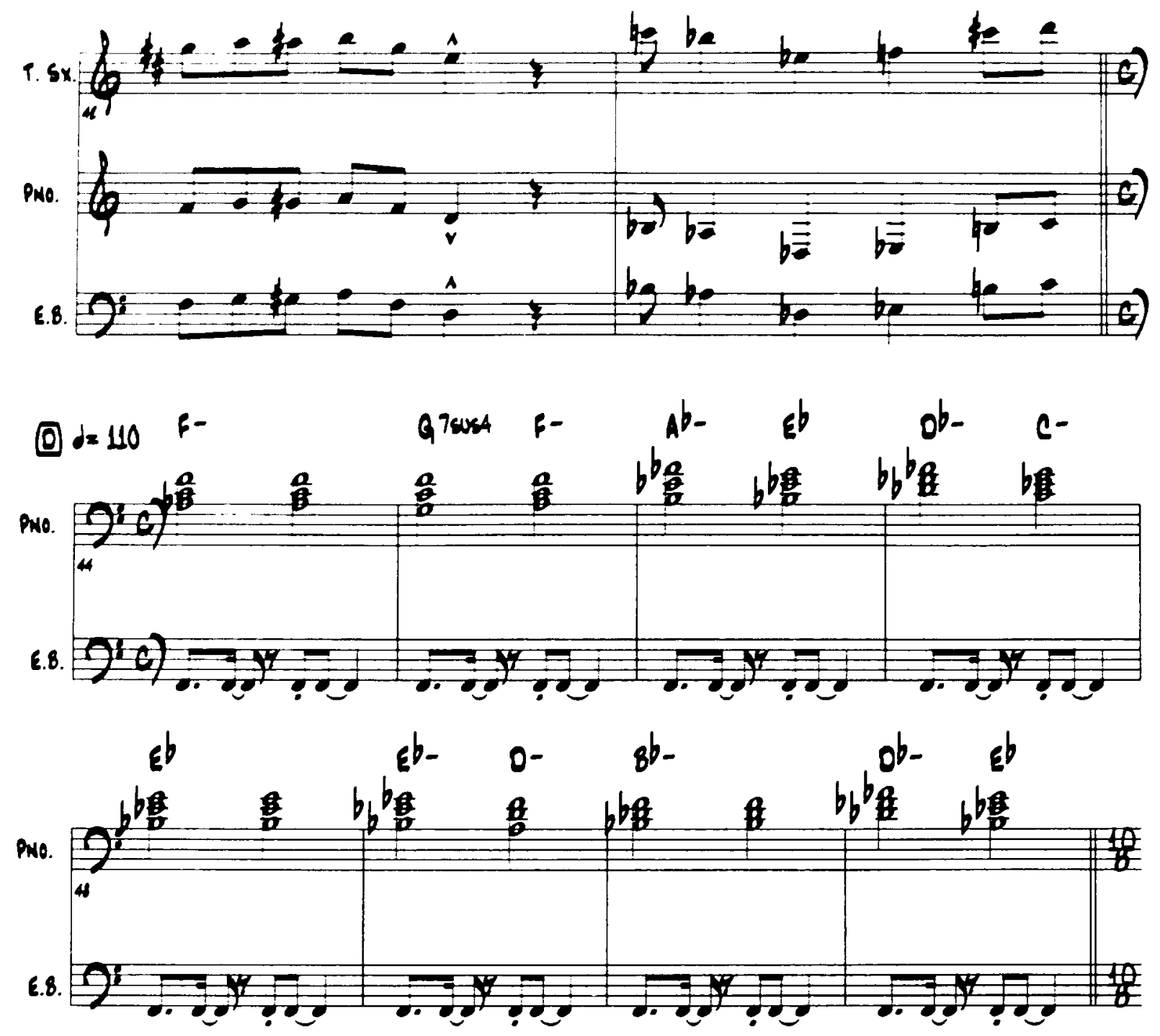
Suraps a Manizuevize
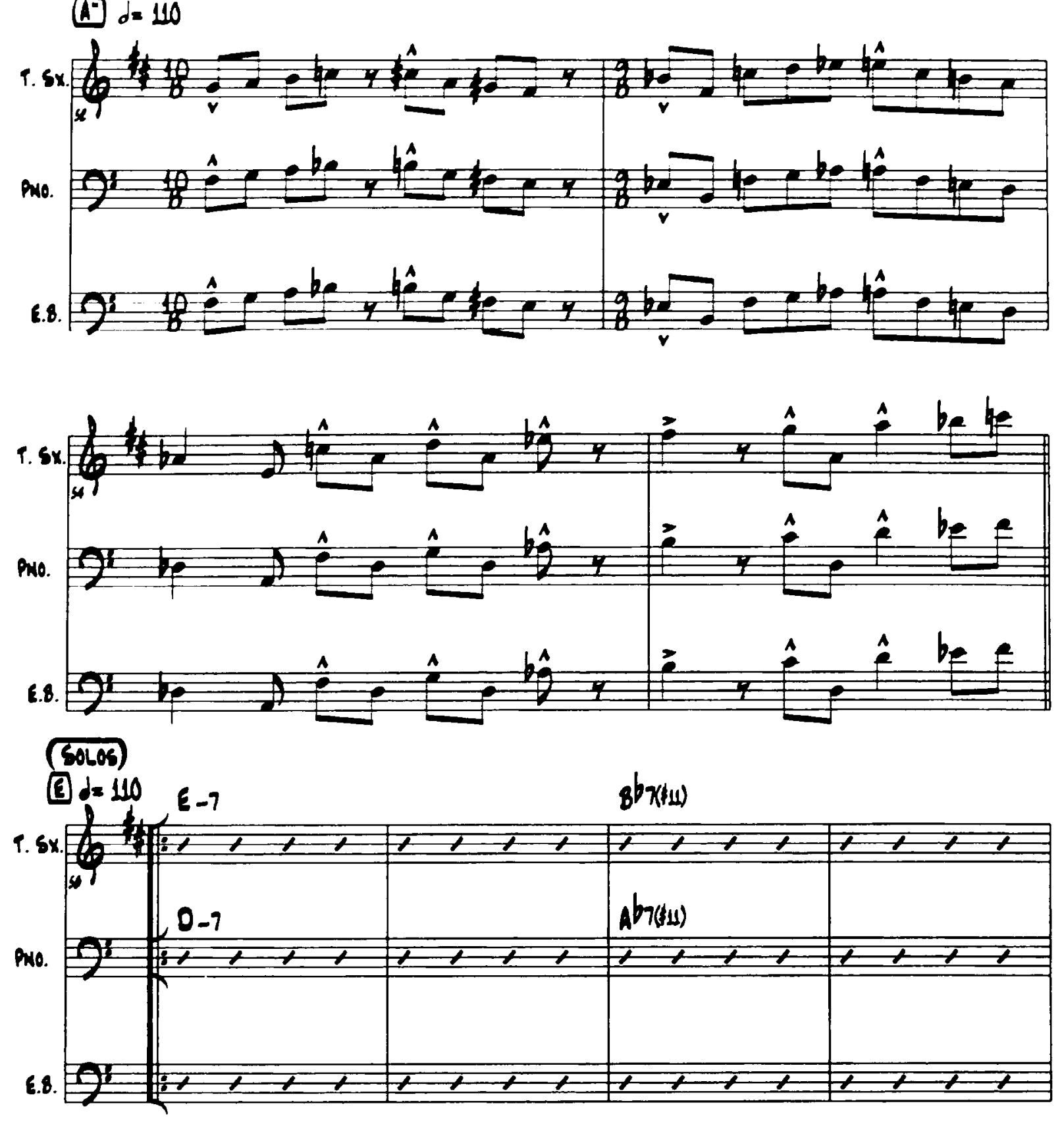

82 


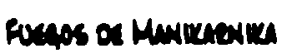
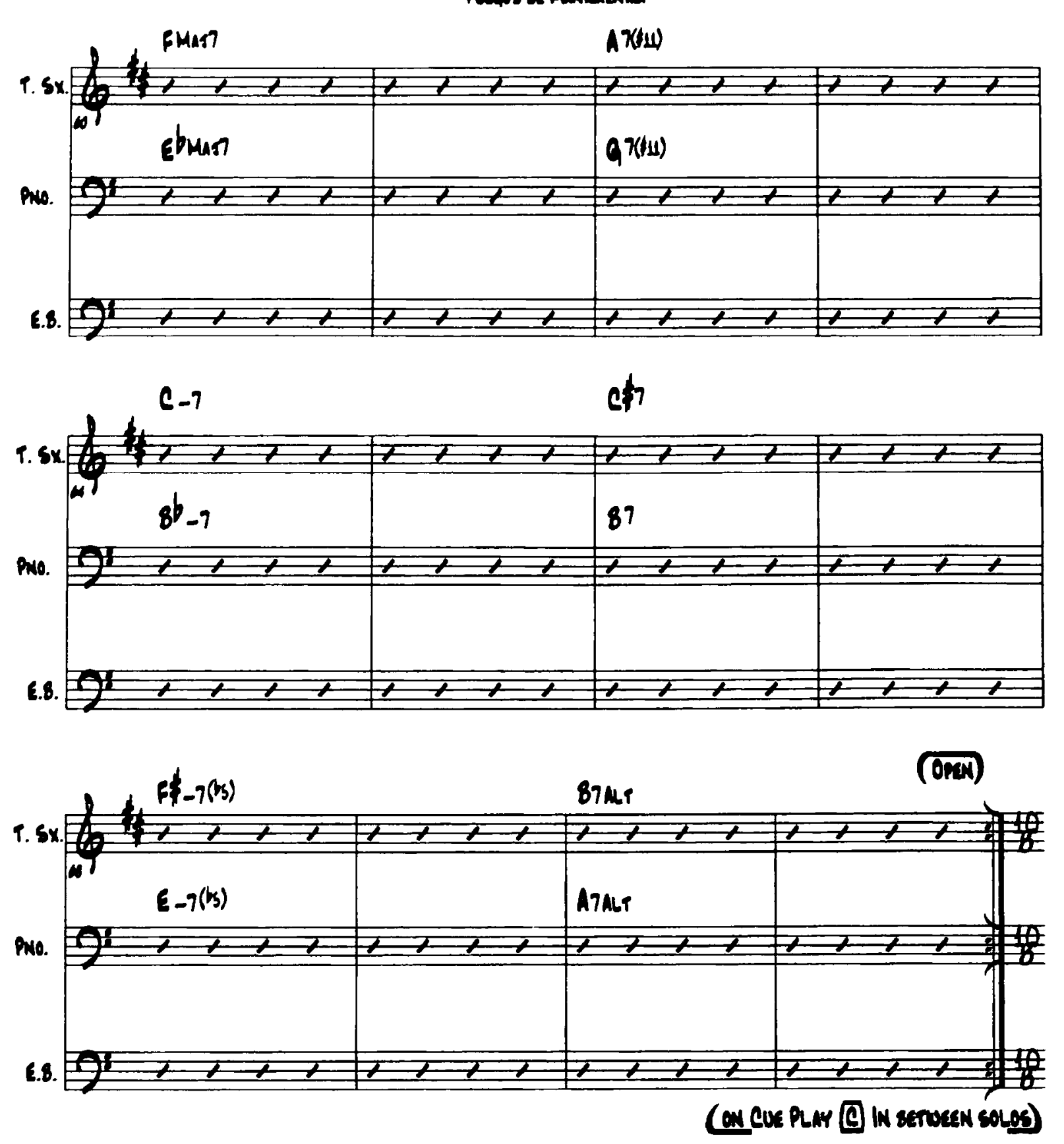

83 

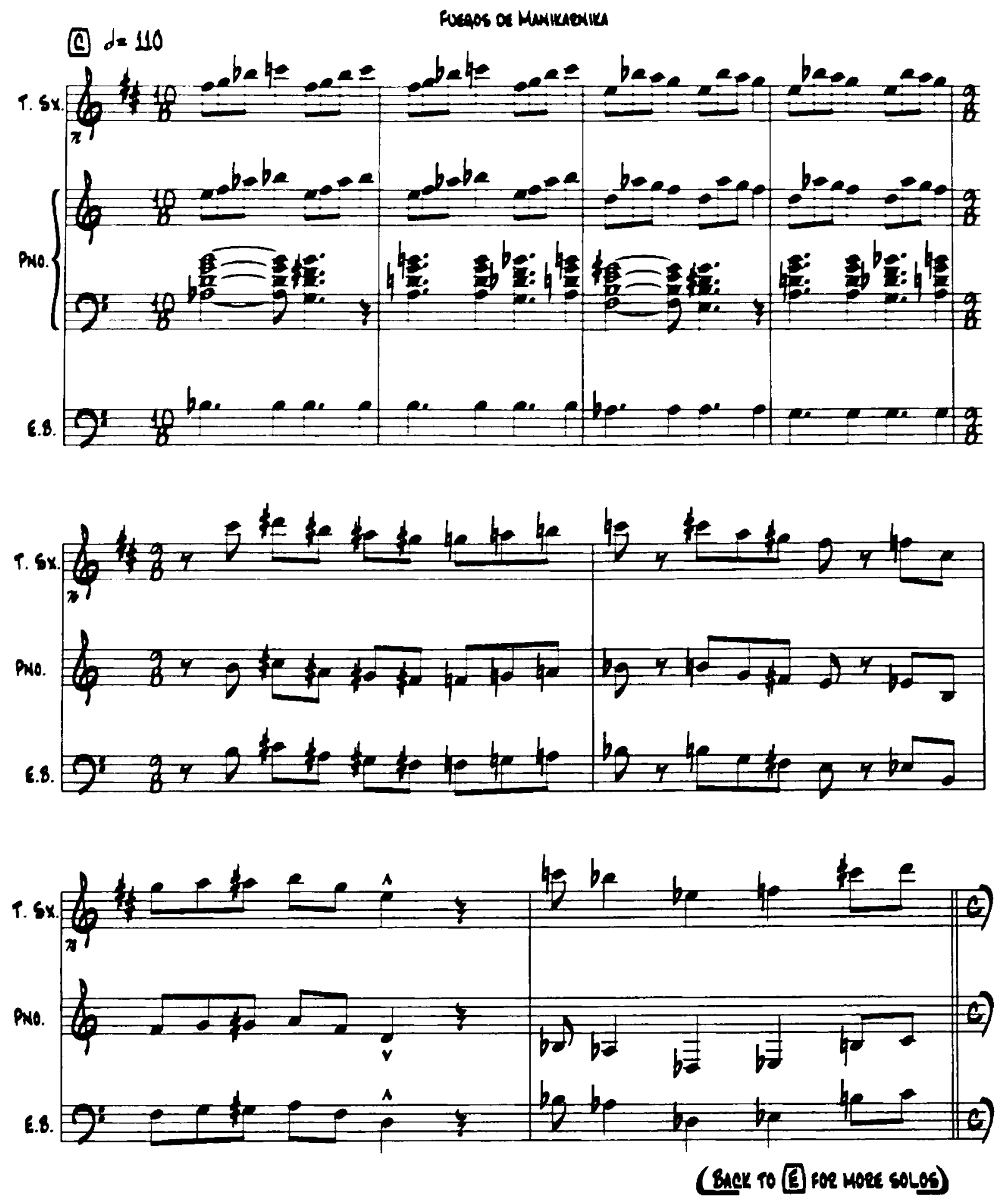

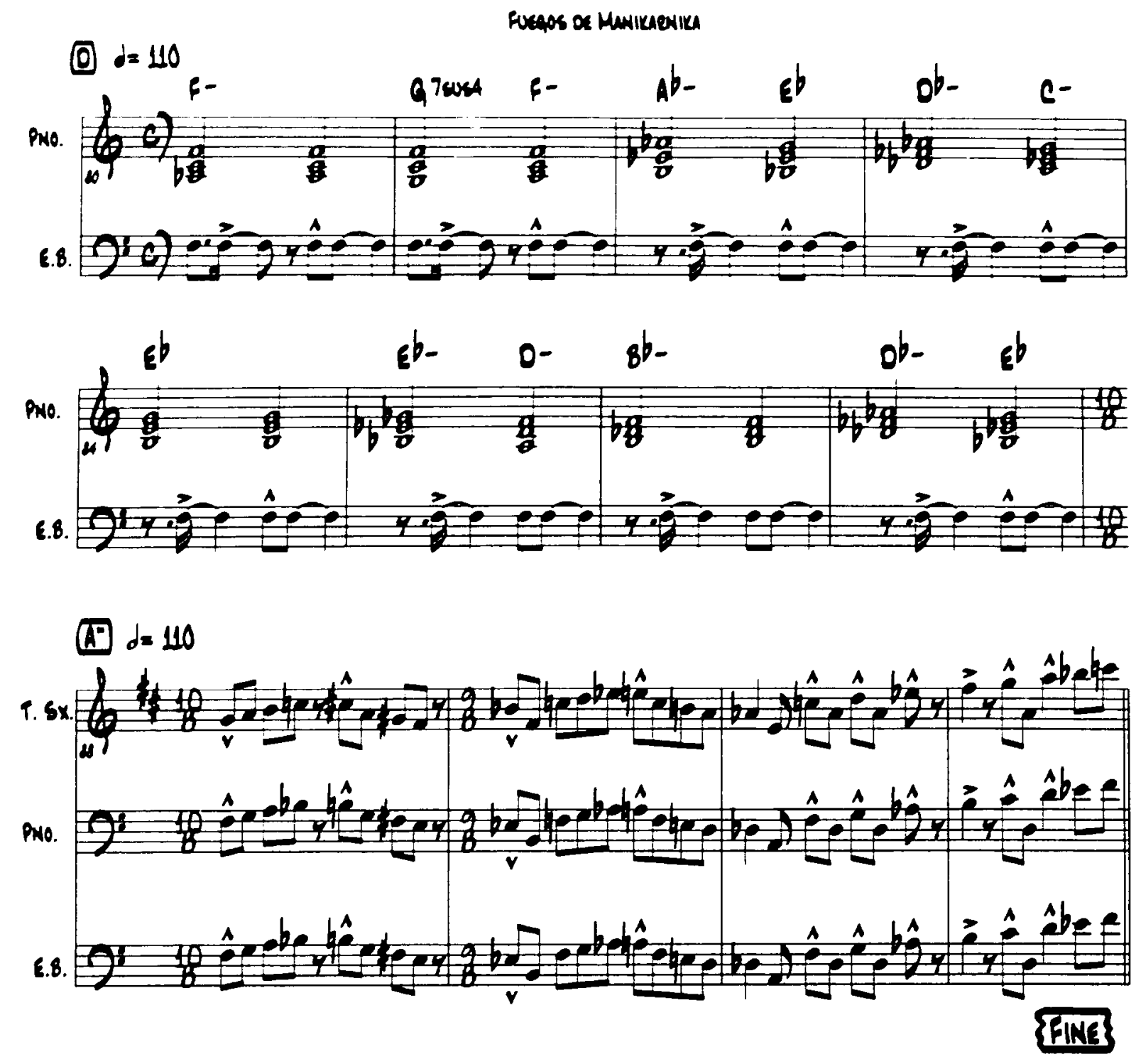